\title{
Evaluation of CESM1 (WACCM) free-running and specified dynamics atmospheric composition simulations using global multispecies satellite data records
}

\author{
Lucien Froidevaux ${ }^{1}$, Douglas E. Kinnison ${ }^{2}$, Ray Wang ${ }^{3}$, John Anderson ${ }^{4}$, and Ryan A. Fuller ${ }^{1}$ \\ ${ }^{1}$ Jet Propulsion Laboratory, California Institute of Technology, Pasadena, CA, USA \\ ${ }^{2}$ National Center for Atmospheric Research, Boulder, CO, USA \\ ${ }^{3}$ School of Earth and Atmospheric Sciences, Georgia Institute of Technology, Atlanta, GA, USA \\ ${ }^{4}$ School of Science, Hampton University, Hampton, VA, USA
}

Correspondence: Lucien Froidevaux (lucienf@jpl.nasa.gov)

Received: 31 May 2018 - Discussion started: 13 June 2018

Revised: 1 March 2019 - Accepted: 13 March 2019 - Published: 10 April 2019

\begin{abstract}
We have analyzed near-global stratospheric data (and mesospheric data as well for $\mathrm{H}_{2} \mathrm{O}$ ) in terms of absolute abundances, variability, and trends for $\mathrm{O}_{3}, \mathrm{H}_{2} \mathrm{O}, \mathrm{HCl}, \mathrm{N}_{2} \mathrm{O}$, and $\mathrm{HNO}_{3}$, based on Aura Microwave Limb Sounder (MLS) data, as well as longer-term series from the Global OZone Chemistry And Related trace gas Data records for the Stratosphere (GOZCARDS). While we emphasize the evaluation of stratospheric models via data comparisons through 2014 to free-running (FR-WACCM) and specified dynamics (SDWACCM) versions of the Community Earth System Model version 1 (CESM1) Whole Atmosphere Community Climate Model (WACCM), we also highlight observed stratospheric changes, using the most recent data from MLS.

Regarding highlights from the satellite data, we have used multiple linear regression to derive trends based on zonal mean time series from Aura MLS data alone, between $60^{\circ} \mathrm{S}$ and $60^{\circ} \mathrm{N}$. In the upper stratosphere, MLS $\mathrm{O}_{3}$ shows increases over 2005-2018 at $\sim 0.1-0.3 \% \mathrm{yr}^{-1}$ (depending on altitude and latitude) with $2 \sigma$ errors of $\sim 0.2 \% \mathrm{yr}^{-1}$. For the lower stratosphere (LS), GOZCARDS O 3 data for 1998 2014 point to small decreases between $60^{\circ} \mathrm{S}$ and $60^{\circ} \mathrm{N}$, but the trends are more positive if the starting year is 2005. Southern midlatitudes $\left(30-60^{\circ} \mathrm{S}\right)$ exhibit near-zero or slightly positive LS trends for 1998-2018. The LS O trends based on 2005-2018 MLS data are most positive $\left(0.1-0.2 \% \mathrm{yr}^{-1}\right)$ at these southern midlatitudes, although marginally statistically significant, in contrast to slightly negative or near-zero trends for 2005-2014. Given the high variability in $\mathrm{LS}_{3}$, and the high sensitivity of trends to the
\end{abstract}

choice of years used, especially for short periods, further studies are required for a robust longer-term LS trend result. For $\mathrm{H}_{2} \mathrm{O}$, upper-stratospheric and mesospheric trends from GOZCARDS 1992-2010 data are near zero (within $\sim 0.2 \% \mathrm{yr}^{-1}$ ) and significantly smaller than trends (within $\sim 0.4-0.7 \% \mathrm{yr}^{-1}$ ) from MLS for 2005-2014 or 2005-2018. The latter short-term positive $\mathrm{H}_{2} \mathrm{O}$ trends are larger than expected from changes resulting from long-term increases in methane. We note that the very shallow solar flux maximum of solar cycle 24 has contributed to fairly large shortterm mesospheric and upper-stratospheric $\mathrm{H}_{2} \mathrm{O}$ trends since 2005. However, given known drifts in the MLS $\mathrm{H}_{2} \mathrm{O}$ time series, MLS $\mathrm{H}_{2} \mathrm{O}$ trend results, especially after 2010, should be viewed as upper limits. The MLS data also show regions and periods of small $\mathrm{HCl}$ increases in the lower stratosphere, within the context of the longer-term stratospheric decrease in $\mathrm{HCl}$, as well as interhemispheric-latitudinal differences in short-term $\mathrm{HCl}$ tendencies. We observe similarities in such short-term tendencies, and interhemispheric asymmetries therein, for lower-stratospheric $\mathrm{HCl}$ and $\mathrm{HNO}_{3}$, while $\mathrm{N}_{2} \mathrm{O}$ trend profiles exhibit anti-correlated patterns.

In terms of the model evaluation, climatological averages for 2005-2014 from both FR-WACCM and SD-WACCM for $\mathrm{O}_{3}, \mathrm{H}_{2} \mathrm{O}, \mathrm{HCl}, \mathrm{N}_{2} \mathrm{O}$, and $\mathrm{HNO}_{3}$ compare favorably with Aura MLS data averages over this period. However, the models at mid- to high latitudes overestimate mean MLS LS O 3 values and seasonal amplitudes by as much as 50\%-60\%; such differences appear to implicate, in part, a transportrelated model issue. At lower-stratospheric high southern lat- 
itudes, variations in polar winter and spring composition observed by MLS are well matched by SD-WACCM, with the main exception being for the early winter rate of decrease in $\mathrm{HCl}$, which is too slow in the model. In general, we find that the latitude-pressure distributions of annual and semiannual oscillation amplitudes derived from MLS data are properly captured by the model amplitudes. In terms of closeness of fit diagnostics for model-data anomaly series, not surprisingly, SD-WACCM (driven by realistic dynamics) generally matches the observations better than FR-WACCM does. We also use root mean square variability as a more valuable metric to evaluate model-data differences. We find, most notably, that FR-WACCM underestimates observed interannual variability for $\mathrm{H}_{2} \mathrm{O}$; this has implications for the time period needed to detect small trends, based on model predictions.

The WACCM $\mathrm{O}_{3}$ trends generally agree (within $2 \sigma$ uncertainties) with the MLS data trends, although LS trends are typically not statistically different from zero. The MLS $\mathrm{O}_{3}$ trend dependence on latitude and pressure is matched quite well by the SD-WACCM results. For $\mathrm{H}_{2} \mathrm{O}$, MLS and SD-WACCM positive trends agree fairly well, but FRWACCM shows significantly smaller increases; this discrepancy for FR-WACCM is even more pronounced for longerterm GOZCARDS $\mathrm{H}_{2} \mathrm{O}$ records. The larger discrepancies for FR-WACCM likely arise from its poorer correlations with cold point temperatures and with quasi-biennial oscillation (QBO) variability. For $\mathrm{HCl}$, while some expected decreases in the global LS are seen in the observations, there are interhemispheric differences in the trends, and increasing tendencies are suggested in tropical MLS data at $68 \mathrm{hPa}$, where there is only a slight positive trend in SD-WACCM. Although the vertical gradients in MLS $\mathrm{HCl}$ trends are well duplicated by SD-WACCM, the model trends are always somewhat more negative; this deserves further investigation. The original MLS $\mathrm{N}_{2} \mathrm{O}$ product time series yield small positive LS tropical trends (2005-2012), consistent with models and with rates of increase in tropospheric $\mathrm{N}_{2} \mathrm{O}$. However, longerterm series from the more current MLS $\mathrm{N}_{2} \mathrm{O}$ standard product are affected by instrument-related drifts that have also impacted $\mathrm{MLS} \mathrm{H}_{2} \mathrm{O}$. The LS short-term trend profiles from MLS $\mathrm{N}_{2} \mathrm{O}$ and $\mathrm{HNO}_{3}$ at midlatitudes in the two hemispheres have different signs; these patterns are well matched by SDWACCM trends for these species.

These model-data comparisons provide a reminder that the QBO and other dynamical factors affect decadal variability in a major way, notably in the lower stratosphere, and can thus significantly hinder the goals of robustly extracting (and explaining) small underlying long-term trends. The data sets and tools discussed here for model evaluation could be expanded to comparisons of species or regions not included here, as well as to comparisons between a variety of chemistry-climate models.
Copyright statement. The author's copyright for this publication is transferred to California Institute of Technology.

\section{Introduction}

State-of-the-art chemistry-climate models (CCMs) are known to reproduce the main features of stratospheric climatology and change, although there have always been some differences between models (e.g., Waugh and Eyring, 2008; SPARC, 2010; Dhomse et al., 2018). Free-running CCMs are used to make long-term simulations of atmospheric composition, as well as predictions of future changes, driven by timedependent boundary conditions for surface concentrations of greenhouse gases and ozone-depleting substances (ODSs), sea surface temperatures and sea ice concentrations, 11-year solar variability, sulfate aerosol surface area density, and tropospheric ozone and aerosol precursor emissions. In more recent years, modeling groups have implemented "specified dynamics" versions that are constrained to meteorological fields (e.g., surface pressure, temperature, and winds). Our main purpose is to evaluate these two types of model runs from CESM1 WACCM, using multispecies satellite-derived global composition data sets; we refer to these two types as FR-WACCM (free-running model) and SD-WACCM (specified dynamics version). The SD-WACCM version has been used in studies ranging from examination of ozone trends (e.g., Solomon et al., 2016; Ball et al., 2017; Wilka et al., 2018 ) to evaluation of galactic cosmic ray influence on ozone (Jackman et al., 2016). This configuration has also been used to study dynamical processes that affect stratospheric ozone (e.g., Khosrawi et al., 2013; Gille et al., 2014) and has contributed to the understanding of satellite occultation instrument differences (Sakazaki et al., 2015). Here, we perform a detailed model/observational analysis of two configurations (FR and SD) using the same modeling system (CESM) and identical tracer advection and chemistry modules. Differences between the two configurations should be caused mainly by the influence of different temperature fields on chemistry and by different mean circulations. The simulations are based on scenarios defined by the ChemistryClimate Model Initiative (CCMI) (Eyring et al., 2013; Morgenstern et al., 2017). Our evaluation focus is on monthly zonal mean series from the models versus satellite-derived data. The main stratospheric series used here are from Aura Microwave Limb Sounder (MLS) data (version 4.2) and from the Global OZone Chemistry And Related trace gas Data records for the Stratosphere (GOZCARDS), which include MLS data from late 2004 onward. GOZCARDS includes merged multi-satellite data files for $\mathrm{O}_{3}, \mathrm{H}_{2} \mathrm{O}$, and $\mathrm{HCl}$, as well as Aura MLS data for $\mathrm{HNO}_{3}$ and $\mathrm{N}_{2} \mathrm{O}$; these five species are used for the evaluations. We focus, in part, on the MLS data sets for 2005-2014 (2014 being the last year of WACCM runs considered here). The regular and nearly uninterrupted daily global coverage of the MLS day and night measure- 
ments leads to minimal sampling-related biases, both for climatological comparisons (Toohey et al., 2013) and trendrelated studies. This data set also has a well characterized set of error bars (see Livesey et al., 2018, for the latest update to the data quality documentation); however, we also note that there are some caveats to take into account regarding longterm stability for some of the MLS species.

In terms of model-data comparisons, we analyze the climatological mean state and goodness-of-fit issues, as well as variability. While one has the expectation that, in general, better fits to the data would be obtained for a specified dynamics run than for a less dynamically constrained run (FRWACCM), one needs to demonstrate this with diagnostics that provide enough differentiation between models that can track each other closely. There have been essentially no trend studies using Aura MLS data by themselves. This data set now covers a sufficiently long period that it becomes useful to investigate such trends, as the analyses deal with one data set only, which can remove potential issues with data merging prior to 2005 , whether related to poorer sampling or to uncertainties in bias removal between data sets. While such uncertainties can be difficult to quantify, attempts have been made in the case of ozone data merging from multiple SBUV (Solar Backscatter Ultraviolet Radiometer) instruments, which display relative biases and drifts (Frith et al., 2017); data merging uncertainties in this case were shown to play a large role regarding overall trend uncertainties. Regarding sampling issues, Millán et al. (2016) showed, based on simulated atmospheric fields, that solar occultation-type sampling can significantly bias trend results, as well as increase the time period required for robust trend detection, compared to emission-type (much denser) sampling. On the downside, a shorter time series will lead to larger uncertainties in derived trends.

We provide (in Sect. 2) an overview of the global stratospheric data sets used here. Brief descriptions of FRWACCM and SD-WACCM are given in Sect. 3. Climatological comparisons between models and Aura MLS data are provided in Sect. 4, in order to assess whether any obvious biases exist; this includes an overview of the main short-term variations, namely the annual oscillation (AO) and semiannual oscillation (SAO). More detailed comparisons of deseasonalized anomaly time series are provided in Sect. 5.1, where we evaluate how well the two model versions fit the data sets, both in terms of closeness of fits and variability. Trend results and comparisons are provided in Sect. 5.2, before the closing summary and discussion in Sect. 6 .

\section{Data sets}

\subsection{Aura MLS}

The Microwave Limb Sounder (MLS) is one of four instruments on NASA's Aura satellite, launched on 15 July 2004.
The MLS antenna scans the atmospheric limb as Aura orbits the Earth in a near-polar sun-synchronous orbit, and the instrument measures thermal emission (day and night) in narrow spectral channels, via microwave radiometers operating at frequencies near $118,190,240$, and $640 \mathrm{GHz}$, as well as a $2.5 \mathrm{THz}$ module to measure OH. MLS (see Waters et al., 2006) has been providing a variety of daily vertical stratospheric temperature and composition profiles $(\sim 3500$ profiles per day per product), with some measurements extending down to the upper tropospheric region and some into the upper mesosphere or higher. For more information and access to the MLS data, the reader is referred to http://disc.sci. gsfc.nasa.gov/Aura/data-holdings/MLS, last access: 4 April 2019; the current data version is labeled $4.2 x$ (with $x$ varying between 0 and 3, depending on the date). Data users interested in MLS data quality and characterization, estimated errors, and related information should consult Livesey et al. (2018), the latest update to the MLS data quality document (available from the MLS website at http://mls.jpl.nasa. gov, last access: 4 April 2019).

\subsection{GOZCARDS}

The data set considered here for longer-term model evaluation analyses is from GOZCARDS, a data record created using satellite-based Level 2 data as source data sets, which were merged into global monthly zonal means for $\mathrm{O}_{3}, \mathrm{H}_{2} \mathrm{O}$, and $\mathrm{HCl}$, going back in time before the (2004) launch of Aura. Readers are referred to the GOZCARDS description and highlights provided by Froidevaux et al. (2015). In brief, for $\mathrm{O}_{3}$, the GOZCARDS version 1.01 (v1.01) data record starts in 1979 with solar occultation data from the first Stratospheric Aerosol and Gas Experiment (SAGE I) and continues with data from SAGE II, the Halogen Occultation Experiment (HALOE), the Upper Atmosphere Research Satellite (UARS) MLS, the Atmospheric Chemistry Experiment Fourier Transform Spectrometer (ACE-FTS, using solar occultation), and Aura MLS. Basically, the overlap time periods for different data sets are used to calculate offsets between zonal mean time series in $10^{\circ}$ wide latitude bins at each pressure level, and the data sets are adjusted to a reference value (SAGE II mean values, for $\mathrm{O}_{3}$, or an average of satellite measurements for $\mathrm{H}_{2} \mathrm{O}$ and $\mathrm{HCl}$ ). Monthly standard deviations are also provided, along with other diagnostic quantities. GOZCARDS data extensions past 2012 were created simply by adding more recent MLS data, appropriately adjusted to account for zonal mean differences between versions, once the MLS $\mathrm{O}_{3}$ v2.2 data became unavailable (for 2013 onward); ACE-FTS data were not included in these more recent years. GOZCARDS $\mathrm{O}_{3}$ has been used for past $\mathrm{O}_{3}$ trend assessments and in comparisons to other data records (e.g., WMO, 2014; Nair et al., 2015; Tummon et al., 2015; Harris et al., 2015; Ball et al., 2017, 2018).

For the GOZCARDS $\mathrm{O}_{3}$ data discussed here, unless otherwise noted, we use GOZCARDS v2.20, a recent improve- 
ment and update to the original version. This data set was provided for an updated assessment of stratospheric ozone by Steinbrecht et al. (2017), as well as for the assessment activities of the Long-term Ozone Trends and Uncertainties in the Stratosphere (LOTUS) project and in preparation for the latest international report on the state of the ozone layer, led by the World Meteorological Organization (WMO). GOZCARDS ozone data updates are also used as part of the yearly "State of the Climate" stratospheric ozonerelated summaries, produced for the Bulletin of the American Meteorological Society (BAMS). For GOZCARDS O 3 $\mathrm{v} 2.20$, the stratospheric retrieval pressure grid is twice as fine as for v1.01; there are now 12 regularly spaced levels per decade change in $\log$ of pressure. UARS MLS $\mathrm{O}_{3}$ data were not included in v2.20, since these retrievals are not readily available on the finer vertical grid (although approximations such as interpolation could be used); also, there is no easy provision of UARS MLS retrieval uncertainties on a finer grid. The most significant change for the new merged $\mathrm{O}_{3}$ is the effect of using the more robust version 7 data from SAGE II (Damadeo et al., 2013). Version 7 uses National Aeronautics and Space Administration (NASA) Global Modeling and Assimilation Office (GMAO) Modern-Era Retrospective Analysis for Research and Applications (MERRA) temperature $(T)$ profile data (Rienecker et al., 2011) in the retrievals, and these values (rather than $T$ from the National Centers for Environmental Prediction, NCEP) also have a significant impact on the conversion of SAGE II $\mathrm{O}_{3}$ from its native density-altitude grid to the GOZCARDS mixingratio-pressure grid. Also, Aura MLS v4.2 $\mathrm{O}_{3}$ data are now used (instead of MLS v2.2); HALOE v19 $\mathrm{O}_{3}$ profiles are included after interpolation to the finer pressure grid before merging. As a result of these changes, we have observed closer agreement and larger correlation coefficients between the Stratospheric Water and Ozone Satellite Homogenized (SWOOSH) ozone data (Davis et al., 2016) and GOZCARDS v2.20 $\mathrm{O}_{3}$ series than between SWOOSH and GOZCARDS v1.01 (SWOOSH also uses SAGE II v7 $\mathrm{O}_{3}$ data). More details regarding the impact of GOZCARDS v2.20 $\mathrm{O}_{3}$ on trends are provided in Sect. 5. We note that no ACE-FTS data were included in this newer version of GOZCARDS $\mathrm{O}_{3}$.

\section{WACCM (CESM1) description and simulations}

WACCM (CESM1) is a chemistry-climate model of the Earth's atmosphere, from the surface to the lower thermosphere (Garcia et al., 2007, 2017; Kinnison et al., 2007; Marsh et al., 2013). WACCM is a superset of the Community Atmosphere Model, version 4 (CAM4), and includes all of the physical parameterizations of CAM4 (Neale et al., 2013) and a finite volume dynamical core (Lin, 2004) for the tracer advection. The horizontal resolution is $1.9^{\circ}$ latitude $\times 2.5^{\circ}$ longitude. The vertical resolution in the lower stratosphere
(LS) ranges from $1.2 \mathrm{~km}$ near the tropopause to $\sim 2 \mathrm{~km}$ near the stratopause; in the mesosphere and thermosphere the vertical resolution is $\sim 3 \mathrm{~km}$. Simulations used here are based on the guidelines from the International Global Atmospheric Chemistry - Stratosphere-troposphere Processes And their role in Climate (IGAC/SPARC) Chemistry-Climate Model Initiative (Morgenstern et al., 2017). Improvements in CESM1 WACCM for CCMI include a modification to the orographic gravity wave forcing, which reduced the cold bias in Antarctic polar temperatures (Garcia et al., 2017; Calvo et al., 2017), and updates to the stratospheric heterogeneous chemistry, which improved the representation of polar ozone depletion (Wegner et al., 2013; Solomon et al., 2015). In this work, there are two CCMI scenarios, spanning the 19902014 period. The first scenario follows the CCMI REF-C1 definition and three ensemble members were completed; this falls under the free-running scenario. We note that all the analyses herein are based on an average of these three simulations. We have checked that the three representations' departures from the average are small enough not to require separate comparisons for each case, when pursuing average or root mean square (rms) differences versus observations, in comparison to differences using the second model scenario (see below); this is also true for the model-data comparisons of rms variability. This first model scenario includes forcing from greenhouse gases $\left(\mathrm{CH}_{4}, \mathrm{~N}_{2} \mathrm{O}\right.$, and $\left.\mathrm{CO}_{2}\right)$, organic halogens, volcanic aerosol surface area density and heating, and 11-year solar cycle variability. The sea surface temperatures are based on observations and the quasi-biennial oscillation (QBO) is nudged to observed monthly mean tropical winds over 86-4 hPa, as described in Matthes et al. (2010).

The second scenario is based on the CCMI REF-C1SD scenario and includes all the forcings of REF-C1, except for additional external QBO nudging. This scenario uses the specified dynamics (SD) option in WACCM (Lamarque et al., 2012). Here, temperature, zonal and meridional winds, and surface pressure are used to drive the physical parameterization controlling boundary layer exchanges, advective and convective transport, and the hydrological cycle. The meteorological analyses are taken from MERRA and the nudging approach is described in Kunz et al. (2011). The QBO circulation is inherent in the MERRA meteorological fields and is therefore synchronized with that in the real atmosphere. The horizontal resolution is the same as the REF-C1 version, and the vertical resolution follows the MERRA reanalysis (from $\sim 1 \mathrm{~km}$ resolution near the tropopause to about $2 \mathrm{~km}$ near the stratopause). The model meteorological fields are nudged from the surface to $50 \mathrm{~km}$; above $60 \mathrm{~km}$, these fields are fully interactive, with a linear transition in between.

Both WACCM versions used here contain an identical representation of tropospheric and stratospheric chemistry (Kinnison et al., 2007; Tilmes et al., 2016). The species included in this mechanism are contained within the $\mathrm{O}_{x}, \mathrm{NO}_{x}, \mathrm{HO}_{x}$, $\mathrm{ClO}_{x}$, and $\mathrm{BrO}_{x}$ chemical families, along with $\mathrm{CH}_{4}$ and its degradation products. In addition, 20 primary non-methane 
hydrocarbons and related oxygenated organic compounds are represented, along with their surface emissions. In total there are 183 species and 472 chemical reactions; this includes 17 heterogeneous reactions on multiple aerosol types (i.e., sulfate, nitric acid trihydrate, and water-ice). For this work, the CESM1 (WACCM) REF-C1 and REF-C1SD simulations will generally be referred to as FR-WACCM and SD-WACCM, respectively. While the runs were originally designed to stop at the end of 2010, for this work, the forcing inputs have been extended through 2014 .

\section{Climatological comparisons and biases}

We first describe some of the major climatological features for the stratospheric species mentioned in the Introduction. We focus on the main differences between average model trace gas abundances from FR-WACCM and SD-WACCM and the corresponding data from Aura MLS for 2005 through 2014; this includes a subsection on annual and semiannual variations.

\subsection{Average abundances}

We provide climatological latitude-pressure contour plots in the Supplement (Fig. S1 for $\mathrm{O}_{3}$ and $\mathrm{H}_{2} \mathrm{O}$; Fig. $\mathrm{S} 2$ for $\mathrm{HCl}$, $\mathrm{HNO}_{3}$, and $\mathrm{N}_{2} \mathrm{O}$ ), showing Aura MLS and WACCM average distributions for 2005-2014. Since such plots do not easily allow one to quantify areas of model-data disagreement, we show in Fig. 1a and b the percent differences between WACCM and MLS climatologies; a positive value means that, on average, the model values exceed the data values. Figure 1c provides a comparison between the models (also as percent differences). We have crossed out the regions in Fig. $1 \mathrm{a}$ and $\mathrm{b}$ where there is little statistical significance in the model-data differences; more specifically, this is where the absolute differences are less than 1.5 times the systematic uncertainties in MLS abundances. These error estimates have been provided in MLS validation and error characterization work as "typical" (global) profiles versus pressure; such estimates for version 4 MLS data are provided by Livesey et al. (2018) and are typically $2 \sigma$ estimates; thus, regions with the most significant differences (above the $3 \sigma$ error level) are shown without crosses. The vertical profile of MLS $\mathrm{O}_{3}$ systematic errors is given in the Supplement (Fig. S3). Past validation references for $\mathrm{MLS} \mathrm{O}_{3}$ include Jiang et al. (2007), Froidevaux et al. (2008a), and Livesey et al. (2008), as well as the more recent work covering many satellite instruments by Hubert et al. (2016). The original MLS data validation work for $\mathrm{H}_{2} \mathrm{O}$ is from Read et al. (2007) and Lambert et al. (2007), who also described $\mathrm{N}_{2} \mathrm{O}$ validation; $\mathrm{MLS} \mathrm{HNO}_{3}$ validation was provided by Santee et al. (2007). Based on Fig. 1, most of the model $\mathrm{O}_{3}$ climatology falls within $5 \%$ to $10 \%$ of the data climatology, except in the upper troposphere and lower stratosphere (UTLS), where SD-WACCM O 3 val-
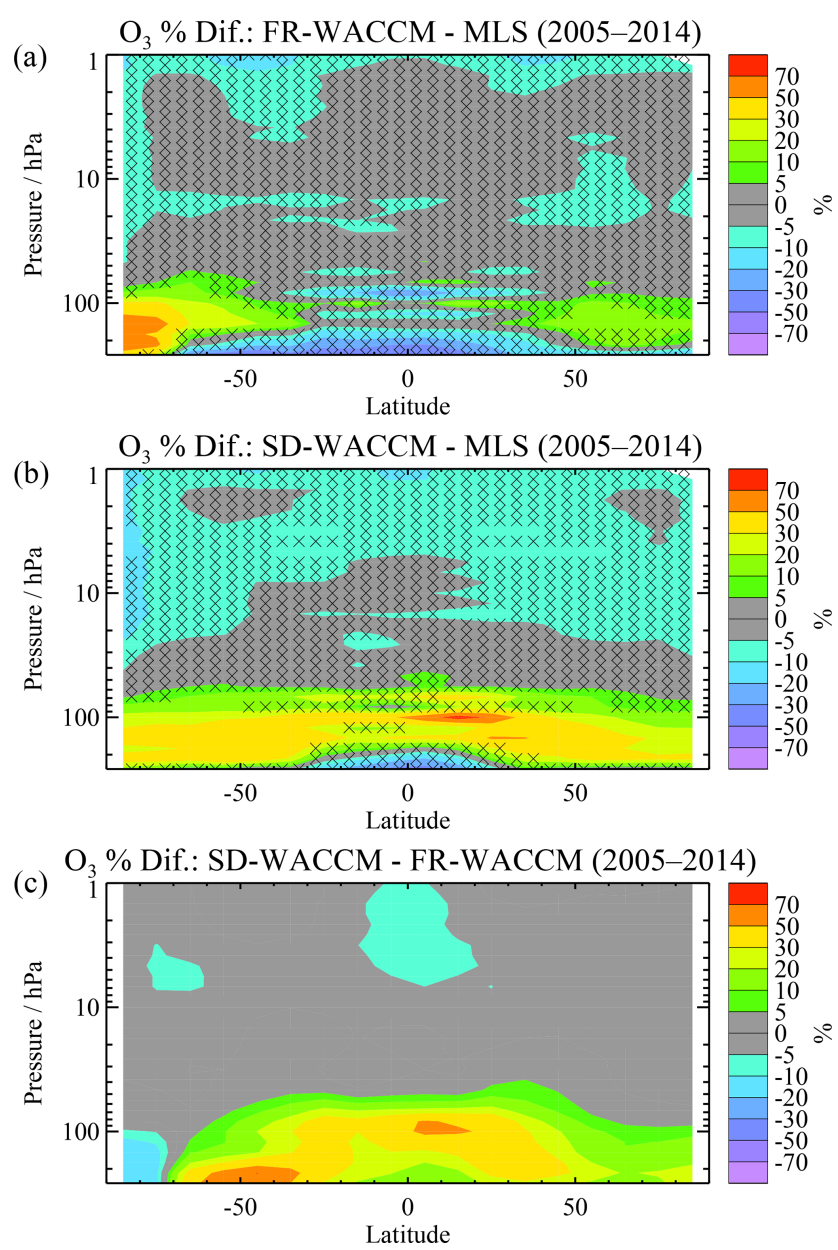

Figure 1. These latitude-pressure contour plots show percent differences $\left(100 \times\right.$ (model-data) / data) for binned climatological $\mathrm{O}_{3}$ from 2005 to 2014 (see Fig. S1 for the average MLS and model values), for (a) the free-running model (average of three FR-WACCM realizations), (b) for the specified dynamics (SD-WACCM) version, and (c) for SD-WACCM - FR-WACCM. Regions that are not crossed out in (a) and (b) are regions where the model climatology differs quite significantly from the data, based on a comparison of the ratio of (absolute) model-data differences to MLS systematic error estimates (see text).

ues are even larger than those from FR-WACCM (Fig. 1c). Our work focuses on the stratosphere, but both FR-WACCM and SD-WACCM average $\mathrm{O}_{3}$ values at low latitudes are lower than the observed means from 215 to $261 \mathrm{hPa}$ (and these levels lie in the upper troposphere at these latitudes); in this region, there are known MLS positive biases versus tropical ozonesonde data, and this could account for part of the apparent model low bias. However, midlatitude $\mathrm{O}_{3}$ from 100 to $215 \mathrm{hPa}$ is biased high in SD-WACCM, with a difference to systematic error ratio larger than 2 to 3 . An illustration of the more significant differences is given in Fig. 2 for $\mathrm{O}_{3}$ data and model series at $215 \mathrm{hPa}$ for $50-60^{\circ} \mathrm{N}$ (which corresponds to lower-stratospheric values). This shows that 


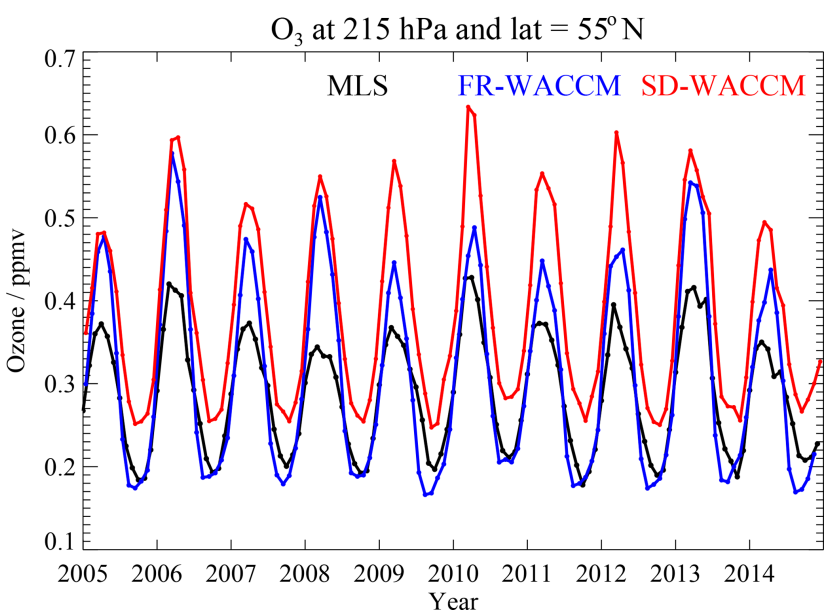

Figure 2. Monthly mean ozone time series at $215 \mathrm{hPa}$ and the $55^{\circ} \mathrm{N}$ latitude bin (for averages over $50-60^{\circ} \mathrm{N}$ ) from MLS, FR-WACCM, and SD-WACCM (see legend for color coding).

both FR-WACCM and SD-WACCM values are larger than the data there, and more so for SD-WACCM, for which the overestimate can be larger than $50 \%$. In relation to this, Imai et al. (2013) showed that SD-WACCM O $\mathrm{O}_{3}$ values are also larger than Superconducting Submillimeter-Wave LimbEmission Sounder (SMILES) $\mathrm{O}_{3}$ in the lowest portion of the stratosphere $(18-20 \mathrm{~km})$. In Fig. 2, we also see that the model $\mathrm{O}_{3}$ annual amplitude (AO) is larger than the observed amplitude; both models overestimate seasonal amplitudes by $\sim 60 \%$. We discuss the AO more generally in the next section. If anything, MLS $\mathrm{O}_{3}$ at midlatitudes is slightly high (by $\sim 5 \%$ ) with respect to a multi-instrument mean based on a number of satellite data sets from the StratosphereTroposphere Processes And their Role in Climate (SPARC) Data Initiative (DI), as discussed by Tegtmeier et al. (2013), who also showed that the MLS $\mathrm{O}_{3}$ seasonal cycle at midlatitudes and $200 \mathrm{hPa}$ is in good agreement with the multiinstrument mean. The MLS measurements discussed here provide generally strongly peaked averaging kernels with a resolution of 2.5 to $4 \mathrm{~km}$ (see Livesey et al., 2018, for sample kernel plots). Smoothing the model profiles using the MLS averaging kernels (and a priori information) gives very little change (less than a few percent for the Fig. 2 example, and even less at higher altitudes) in $\mathrm{O}_{3}$ abundances and seasonal cycles, and we see no real need to use such smoothing for our comparisons. The significant model-data differences in Figs. 1 and 2 are not caused by this sort of issue. The midlatitude $\mathrm{O}_{3}$ differences mentioned above require more detailed investigations but appear to implicate (in part) a transportrelated issue in these models.

Figure 3 is the $\mathrm{H}_{2} \mathrm{O}$ analog of Fig. 1 but for pressures reaching up to $0.01 \mathrm{hPa}$; again, a typical profile of MLS systematic error estimates (Livesey et al., 2018) was used to define regions with the most statistically significant model-data differences; there are almost no such regions in Fig. 3. We
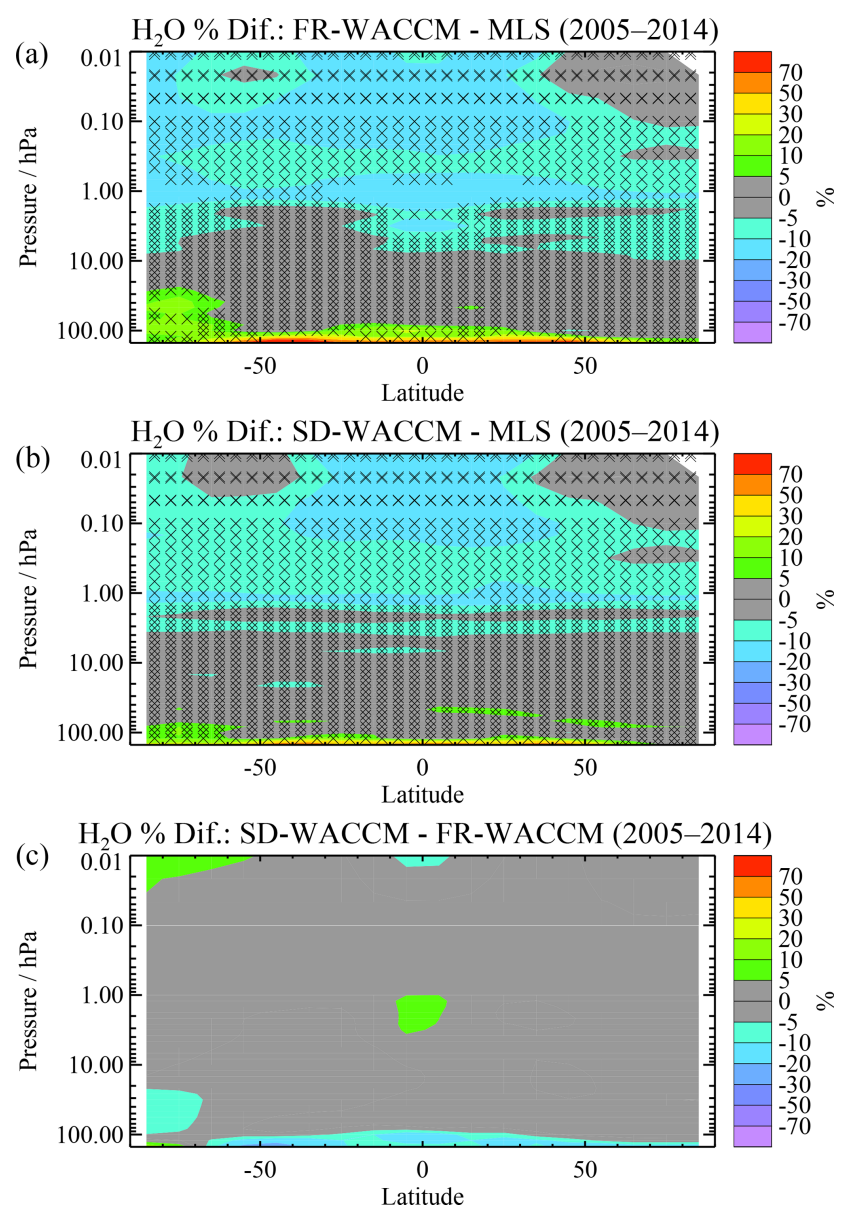

Figure 3. Same as Fig. 1 but for stratospheric and mesospheric water vapor.

note that $\mathrm{MLS} \mathrm{H}_{2} \mathrm{O} v 3$ stratospheric data exhibit a slight high bias (of a few to $5 \%$ ) versus multi-instrument means, with a somewhat larger positive bias (of $\sim 10 \%$ ) in the lower mesosphere (Hegglin et al., 2013). Such biases are within the expected measurement systematic errors. MLS version 4 stratospheric $\mathrm{H}_{2} \mathrm{O}$ data show essentially no systematic change versus version 3 (Livesey et al., 2018). FR-WACCM and SDWACCM $\mathrm{H}_{2} \mathrm{O}$ mean values are on the low side (by $\sim 5-$ $15 \%$ ) relative to MLS $\mathrm{H}_{2} \mathrm{O}$ in the upper stratosphere and in most of the mesosphere (see Fig. 3), implying that the models are in good agreement with the SPARC DI multi-instrument mean $\mathrm{H}_{2} \mathrm{O}$. There is independent evidence that $\mathrm{MLS} \mathrm{H}_{2} \mathrm{O}$ has a dry bias near the hygropause (at the low end of the vertical range shown in Fig. 3, where the bottom level is $150 \mathrm{hPa}$ ); this has been known for some time (Read et al., 2007; Vömel et al., 2007). This is also consistent with the existence of a model high bias relative to MLS near $150 \mathrm{hPa}$. The $\mathrm{H}_{2} \mathrm{O}$ model-data comparisons are generally in agreement within the systematic errors, and the level of agreement is slightly better in the case of SD-WACCM. 

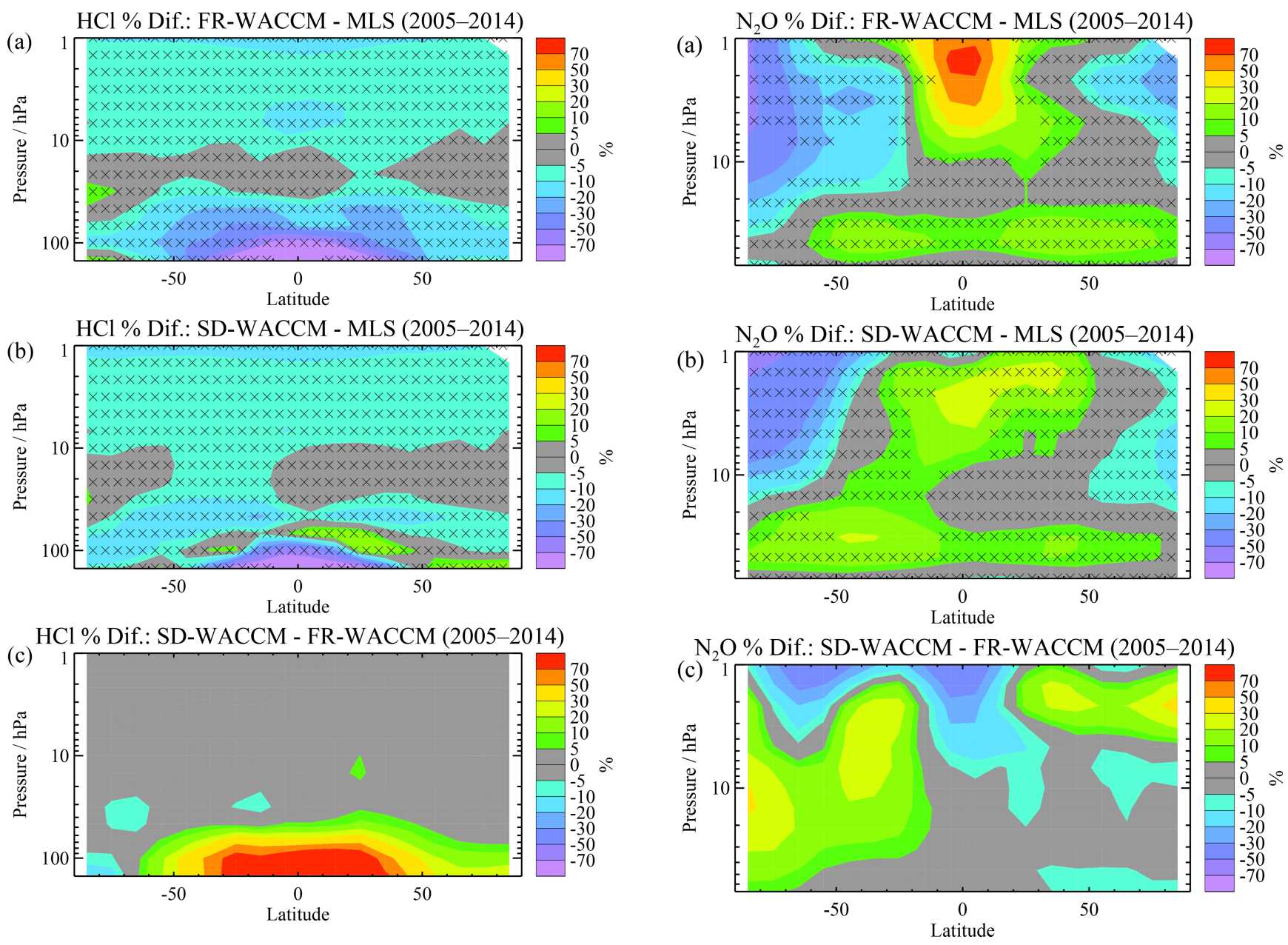

Figure 4. Same as Fig. 1 but for stratospheric $\mathrm{HCl}$.

For $\mathrm{HCl}$, the climatological comparisons of Fig. 4 show that both models exhibit a small $(5 \%-10 \%)$ low bias versus MLS $\mathrm{HCl}$ in much of the stratosphere, with a stronger negative model bias in the tropics between 100 and $150 \mathrm{hPa}$. The model-data relative biases in stratospheric $\mathrm{HCl}$ are generally within the MLS $\mathrm{HCl}$ systematic errors. MLS $\mathrm{HCl}$ is slightly on the high side of multi-instrument mean climatological results provided in the SPARC DI report (SPARC, 2017). The small negative model bias in the upper stratosphere could also arise from the lack of a sufficiently pronounced decrease in upper-stratospheric MLS $\mathrm{HCl}$, as a result of the interruption in the main MLS HCl (band 13) data after early 2006 (Livesey et al., 2018). There is also a known positive bias in MLS tropical $\mathrm{HCl}$ at $150 \mathrm{hPa}$ (Froidevaux et al., 2008b), so model underestimates in this region are not a sign of model weakness. We also note that both models exhibit a systematic difference versus LS $\mathrm{HCl}$ observations (with larger differences for SD-WACCM), as well as a downward sloping pattern (equator to pole) in the Southern Hemisphere (SH) and smaller mean differences (for SD-WACCM) in the Northern Hemisphere (NH).

Figure 5. Same as Fig. 1 but for stratospheric $\mathrm{N}_{2} \mathrm{O}$.

Figure 5 provides average comparisons for $\mathrm{N}_{2} \mathrm{O}$; this species is long-lived in the lower stratosphere, which means that good (or poor) model-data agreement in this region can confirm (or deny) accurate model representations of the dynamics. While mean lower-stratospheric $\mathrm{SH} \mathrm{N}_{2} \mathrm{O}$ values are larger for SD-WACCM than for FR-WACCM (Fig. 5c), the mean fit for SD-WACCM is not significantly better. The most significant climatological differences with respect to the error bars are in the upper stratosphere at low latitudes; in this region, SD-WACCM agrees somewhat better with MLS. However, this is also where the data values decline with height, towards the limits of the MLS sensitivity. Not too surprisingly, this is also where the SPARC DI results for $\mathrm{N}_{2} \mathrm{O}$ show the largest scatter in terms of percent differences (often exceeding 10\%-20\%; see SPARC, 2017).

Finally, the comparisons for $\mathrm{HNO}_{3}$ (Fig. 6) reveal very few areas of model-data disagreements outside the systematic uncertainties. However, there is a model underestimation by both WACCM versions, especially in the polar upper stratosphere; this will be discussed more later. At high latitudes in the lower stratosphere, the models tend to overestimate 


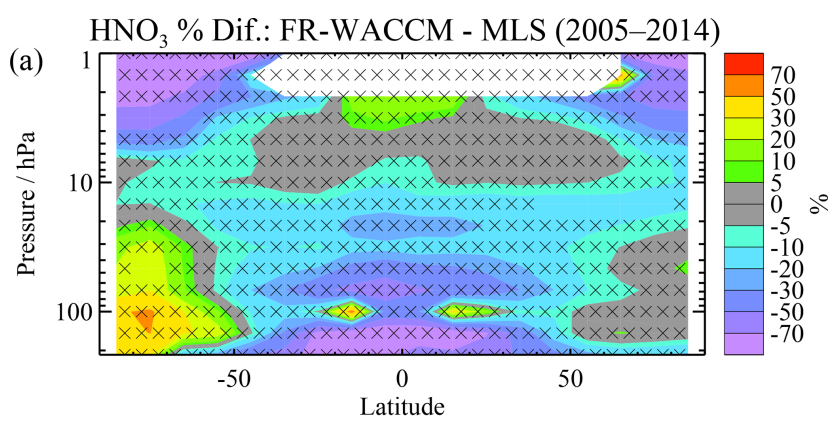

WACCM than the corresponding mean $\mathrm{HCl}$ rate of change from MLS (Fig. 7a). Grooß et al. (2018) recently discussed this $\mathrm{HCl}$ model-data discrepancy for dark polar vortex conditions, in comparison to simulations using the Chemical Lagrangian Model of the Stratosphere (CLAMS), which shows even larger $\mathrm{HCl}$ discrepancies. These authors discuss possible mechanisms and uncertainties, and they argue that additional decomposition of condensed-phase $\mathrm{HNO}_{3}$ might play a role, possibly via galactic cosmic ray impacts. Since this rapid decline in $\mathrm{HCl}$ occurs during polar night, this $\mathrm{HCl}$ issue does not lead to much difference in polar ozone loss rates, which only become significant during sunlit conditions (early spring). Figure 7 confirms that, on average, the SD-WACCM $\mathrm{O}_{3}$ decline and rise match the data well. We also note that FR-WACCM shows smaller-than-observed declines in $\mathrm{HNO}_{3}$ and $\mathrm{H}_{2} \mathrm{O}$, whereas SD-WACCM matches these observations much better. The temperature panel (Fig. 7e) gives a possible reason for these differences, as $T$ from FR-WACCM is larger by a few degrees during the coldest phase than $T$ from SD-WACCM (MERRA-based) and larger than the MLS-derived values. This would lead to less irreversible denitrification and dehydration. The nature of the Fig. 7 results is similar at other lower-stratospheric pressures, although there is some variability in the magnitude of the differences. Over the Arctic region (not shown here), temperature-related differences are not as large as over Antarctica, but similar model-data differences in the early winter rate of $\mathrm{HCl}$ decline exist there also (as mentioned by Grooß et al., 2018).

As an addendum regarding the evaluation of models in comparison to data sets, we provide in Appendix A1 the results of a model grading approach used before (e.g., Douglass et al., 1999; Waugh and Eyring, 2008). We find that this grading method often leads to low grades (see Fig. A1), if applied using systematic uncertainty estimates from the MLS team (Livesey et al., 2018). The model results, as good as they are in many respects, cannot always match the data closely enough, at least based on such grades, although this grading formulation can be reconsidered or slightly modified. For example, the multiplicative error factor (see Eq. A1) can be increased (from 2 to 4 ) to force these grades to span a more useful range (see Fig. A2); some similarities to the percent difference diagnostics used here are noted in Appendix A1.

\subsection{Annual and semiannual cycles}

Figure 8 displays the amplitudes of annual and semiannual variations for MLS $\mathrm{O}_{3}$ and WACCM runs for 20052014. These results come from a simple regression fit to the monthly mean series in each latitude-pressure bin. The primary time dependence of the fitted function is given by additive sine and cosine terms (with 12-month and 6-month periods), in addition to constant and linear trend terms; the $\mathrm{AO}$ and SAO amplitudes are given by the square root of the sum of the squares of the corresponding fitted coefficients. We see from Fig. 8 that the overall data and model 
Averages (2005-2014) for 70-80 S at $46 \mathrm{hPa}$ : Aura MLS FR-WACCM SD-WACCM

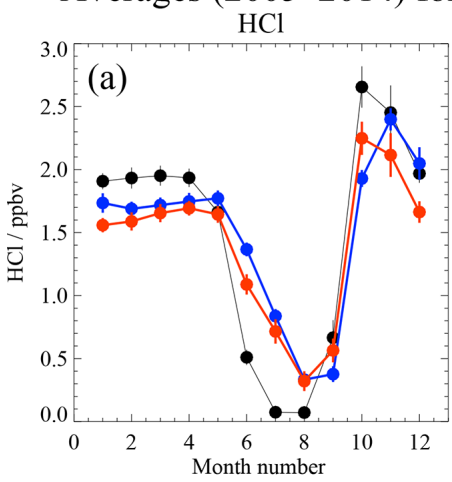
$\mathrm{HNO}_{3}$ $\mathrm{H}_{2} \mathrm{O}$
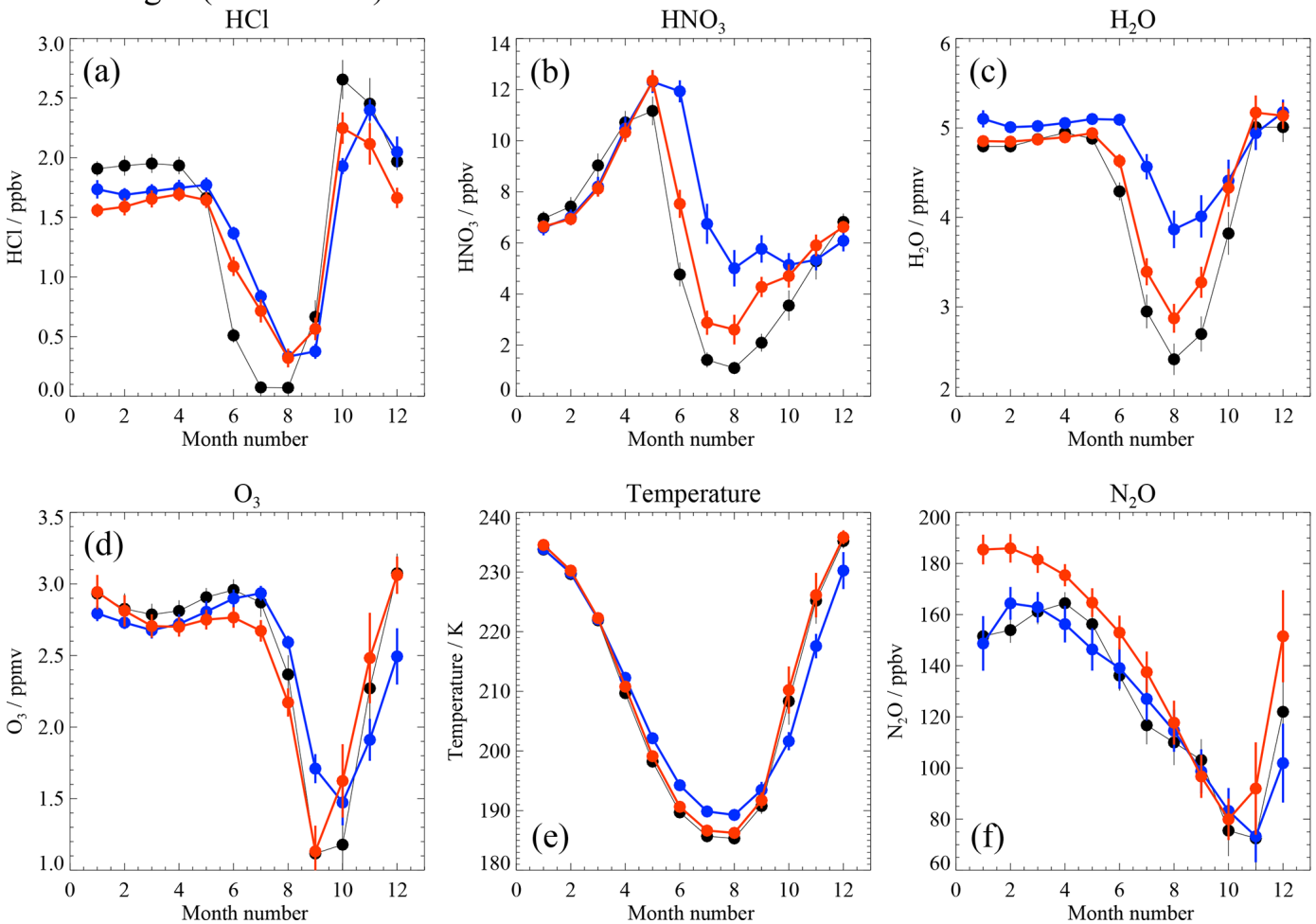

Figure 7. Each of the panels shows average seasonal changes from 2005 to 2014 for the $70-80^{\circ} \mathrm{S}$ region at $46 \mathrm{hPa}$. Data values (black) are from Aura MLS and model comparisons (FR-WACCM in blue, SD-WACCM in red) are provided for $\mathrm{HCl}(\mathbf{a}), \mathrm{HNO}_{3}(\mathbf{b}), \mathrm{H}_{2} \mathrm{O}(\mathbf{c}), \mathrm{O}_{3}(\mathbf{d})$, temperature (e), and $\mathrm{N}_{2} \mathrm{O}$ (f). For each month, the error bars represent twice the standard errors in the means, based on the set of 10-monthly averages (from 2005 through 2014).

patterns of $\mathrm{AO}$ and SAO variability are quite similar. The $\mathrm{O}_{3} \mathrm{AO}$ amplitudes peak at mid- to upper-stratospheric levels, with high-latitude variations also observed as a result of the effects of winter and spring polar chemistry and dynamics. The lower-stratospheric peak AO amplitudes are more prominent over the southern polar regions, where stronger $\mathrm{O}_{3}$ depletion occurs on a seasonal basis. These MLS $\mathrm{O}_{3}$ $\mathrm{AO}$ patterns are similar to those obtained by Schoeberl et al. (2008), using a much shorter period (September 2004 to December 2006); the same holds for other species $\left(\mathrm{H}_{2} \mathrm{O}\right.$ and $\mathrm{HCl}$ ). The observed $\mathrm{SAO}$ amplitude for $\mathrm{O}_{3}$ exhibits strong peaks in the upper stratosphere, both in the tropics and at high latitudes. The anti-correlation between $\mathrm{O}_{3}$ and temperature as a result of temperature-dependent photochemical production and loss terms for $\mathrm{O}_{3}$ has long been known to cause most of the $\mathrm{O}_{3}$ variability in the upper stratosphere (Perliski et al., 1989). The AO and SAO amplitudes obtained in that and other past studies (e.g., Ray et al., 1994) are similar to the patterns shown here. If we look more closely (and based on AO amplitude ratio plots not shown here), there are often $\mathrm{O}_{3} \mathrm{AO}$ amplitudes $20 \%-80 \%$ larger than those derived from MLS data for both WACCM runs in the lower stratosphere (from $50 \mathrm{hPa}$ at low latitudes to $215 \mathrm{hPa}$ at high latitudes). Such model overestimates of the AO amplitude were shown in Fig. 2. Outside of this region, we observe somewhat closer fits to the MLS AO amplitudes for the SD-WACCM version, and both models track the data and each other well, with AO amplitudes typically within a range of $\sim 25 \%$. For the Antarctic lower stratosphere, the timing and magnitude of the seasonal recovery after the ozone hole plays a role, and we have observed that SD-WACCM generally fits the MLS data better than FR-WACCM does. In the tropical upper stratosphere, where the $\mathrm{SAO}$ is larger than the $\mathrm{AO}$ (see Fig. 8), the SD-WACCM results match the observed SAO amplitudes slightly better than those from FR-WACCM. Despite the existence of a few model-data differences, these AO and SAO amplitude comparisons, coupled with our examination of model/data amplitude ratio plots as well as the time series (which include the phase information), do not elicit major concerns regarding the model characterization of the primary processes expected to govern these modes of $\mathrm{O}_{3}$ variability. The study of dynamical forcing mechanisms in relation to such modes continues to be an active area of research (for example see Ern et al., 2015; Smith et al., 2017).

For $\mathrm{H}_{2} \mathrm{O}$, a similar overview of the AO and SAO amplitudes is given in Fig. 9, which covers the range from 100 to $0.01 \mathrm{hPa}$. A peak in these amplitudes resulting from seasonal downward transport before the winter, followed by win- 

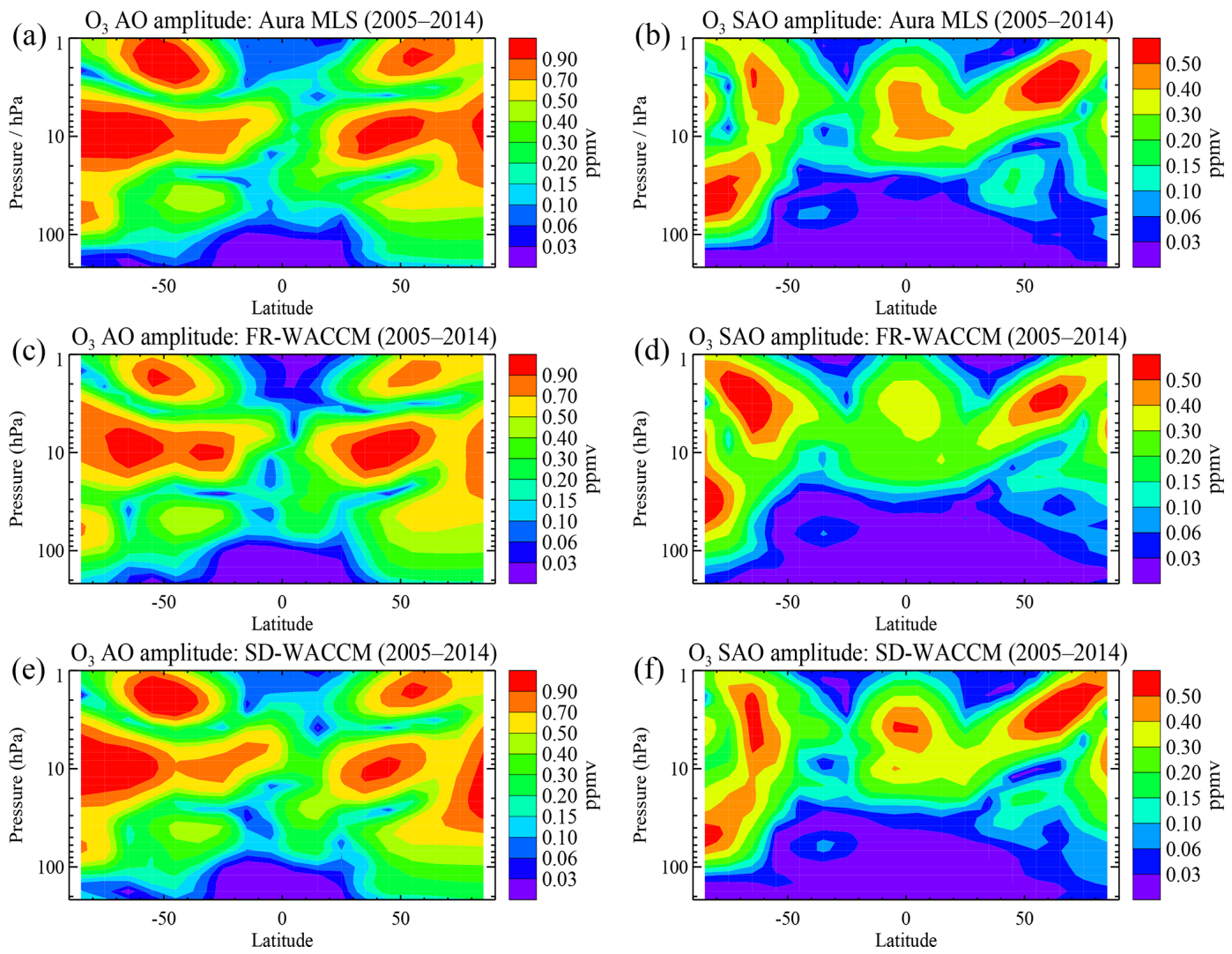

Figure 8. Amplitude of the stratospheric ozone annual cycle (a, c, e) and semiannual cycle (b, d, f) for Aura MLS (a, b), FR-WACCM (c, d), and SD-WACCM (e, f), based on fits to time series from 2005 through 2014.

tertime dehydration, is observed in the lower-stratospheric southern polar region; we note that SD-WACCM results match this feature better than FR-WACCM does. Other features include the Southern Hemisphere's upper-stratospheric AO peak in the extra-tropics. This has been seen by many satellite measurements (see Lossow et al., 2017a). Lossow et al. (2017b) explained this "island" feature in more detail; they argue that vertical advection tied to the upper branch of the Brewer-Dobson circulation largely explains the seasonal highs (lows) via downwelling (upwelling). They also show that an $\mathrm{AO}$ maximum is observed as well in other species in roughly the same region, including in $\mathrm{N}_{2} \mathrm{O}$ MIPAS (Michelson Interferometer for Passive Atmospheric Sounding) data. We confirm this behavior (see also Fig. S5) from the $\mathrm{N}_{2} \mathrm{O}$ AO amplitude feature observed in MLS data, as well as in the model runs (and more so in SD-WACCM). The derived $\mathrm{AO}$ and $\mathrm{SAO}$ amplitude patterns in $\mathrm{H}_{2} \mathrm{O}$ from Lossow et al. (2017a) are consistent with what we find; this includes the peak values in the upper stratosphere and mesosphere, attributed to combined effects of photochemistry and vertical transport. For ozone, a dominant feature in the SAO amplitude exists in the tropical upper stratosphere; see Lossow et al. (2017a) for a brief review of past work explaining such dynamically driven features for $\mathrm{H}_{2} \mathrm{O}$. While there is generally a good level of model-data agreement in the main $\mathrm{H}_{2} \mathrm{O}$ AO and SAO patterns, both WACCM comparisons tend to underestimate observed $\mathrm{AO}$ and $\mathrm{SAO}$ amplitudes in the lower stratosphere and overestimate AO amplitudes in the SH mesosphere, while slightly underestimating mesospheric SAO amplitudes in both polar regions. The largest amplitude differences reach a factor of 2 , in places, for the lowerstratospheric model underestimates; however, we note that this is also the region where $\mathrm{AO}$ and $\mathrm{SAO}$ amplitudes are smallest (typically $<0.1 \mathrm{ppmv}$ ).

For $\mathrm{N}_{2} \mathrm{O}$, we already mentioned the existence of the upperstratospheric AO peak (the "island" feature described by Lossow et al., 2017b) in the southern hemispheric extratropical region. This is similar to the $\mathrm{H}_{2} \mathrm{O}$ AO amplitude maximum feature, but the $\mathrm{N}_{2} \mathrm{O}$ seasonal variations are anti-correlated with $\mathrm{H}_{2} \mathrm{O}$, as demonstrated by Lossow et al. (2017b), using MIPAS data (and as is also apparent in MLS time series, not shown here). Furthermore, we observe in Fig. S5 a somewhat better match in the $\mathrm{AO}$ and $\mathrm{SAO} \mathrm{N}_{2} \mathrm{O}$ amplitude patterns for SD-WACCM than for FR-WACCM versus MLS, in particular for tropical to southern midlatitudes. This is also manifested in better time series fits for SD-WACCM, besides the closer match in average values; this is what one would generally expect from these two model versions. For $\mathrm{HCl}$ and 

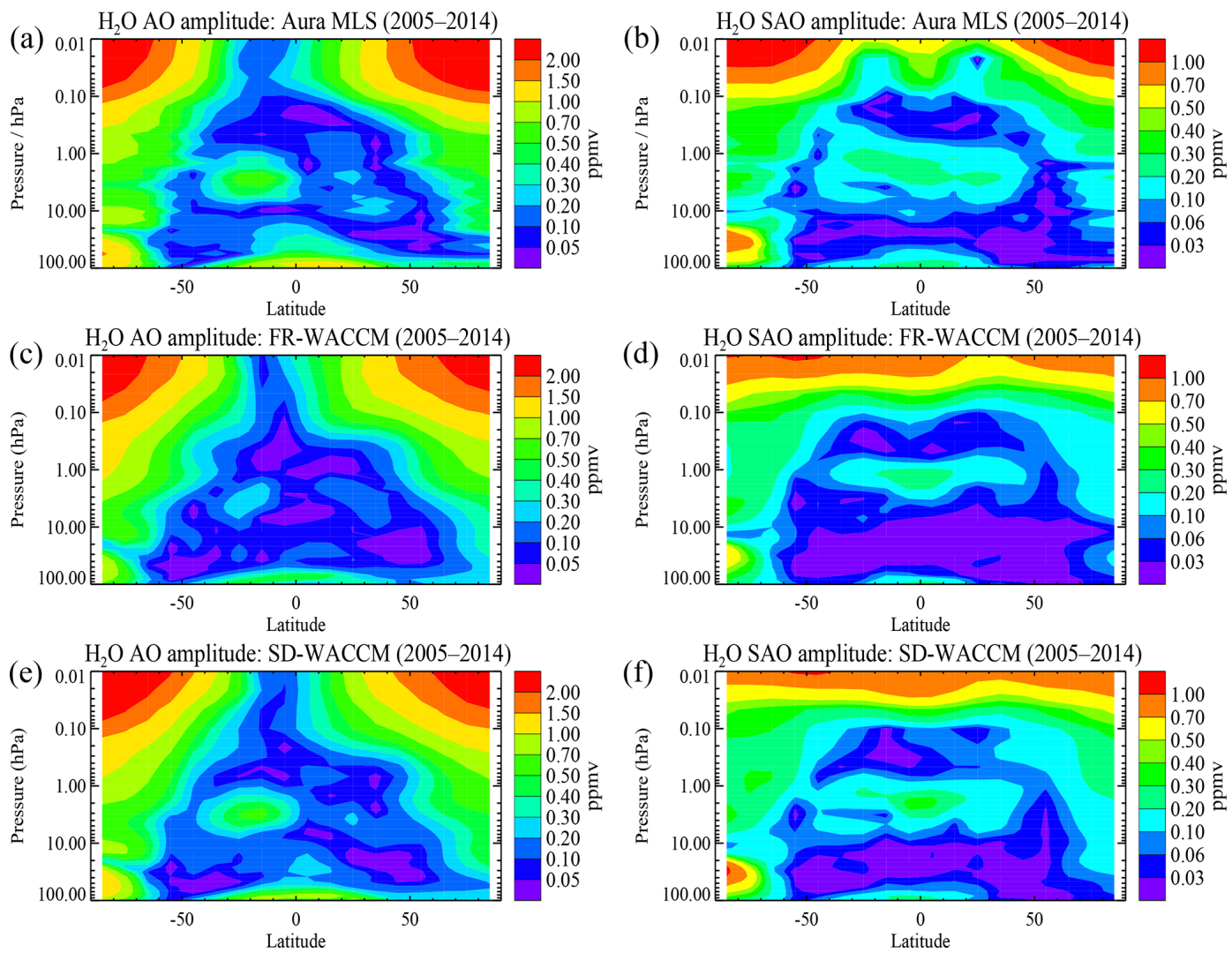

Figure 9. Same as Fig. 8 but for $\mathrm{H}_{2} \mathrm{O}$ annual and semiannual cycles in the stratosphere and mesosphere.

$\mathrm{HNO}_{3}$, the $\mathrm{AO}$ and $\mathrm{SAO}$ amplitudes are dominated by the variations at high latitudes (see Figs. S6 and S7). The model $\mathrm{HCl}$ upper-stratospheric $\mathrm{AO}$ and $\mathrm{SAO}$ amplitudes match up fairly well with the observed amplitudes, despite the aforementioned issues relating to MLS upper-stratospheric $\mathrm{HCl}$ trends. For $\mathrm{HNO}_{3}$, the main $\mathrm{AO}$ and SAO model features follow the MLS patterns, although there is a model underestimation of the amplitudes in the upper-stratospheric polar regions, because these models do not properly capture the observed recurrences of enhanced $\mathrm{HNO}_{3}$, as mentioned earlier (see also Sect. 5).

\section{Time series comparisons}

\subsection{Anomaly time series: fits and variability}

\subsubsection{Fits}

We wish to evaluate which of the two WACCM models provides a better match, or fit, to the temporal variations in observed deseasonalized anomalies. We would expect SDWACCM to generally fit these anomalies better than FRWACCM. We calculate a diagnostic of model fit to the data by using the rms differences between these deseasonalized model and data series and normalize by dividing this quan- tity by the rms of the data anomalies themselves. A diagnostic value much less than unity means that the match to the series is much smaller than the typical variability; this also implies a good fit to observed anomalies. In Appendix A2, we provide the mathematical expression for this "rms difference diagnostic". A better model fit to the observations will be given by a smaller rms difference diagnostic value. We also calculate the (Pearson) correlation coefficients, $R$, between model and data anomalies, and we use $R^{2}$ as another measure of goodness of fit for the models. The first diagnostic is unitless and does not depart too much from the 0 to 1 range; $R^{2}$ is limited to the 0 to 1 range, with larger values indicating a higher degree of linear correlation. We also use these two diagnostics together, by calculating the ratio of $R^{2}$ over the rms difference diagnostic to obtain a "combined diagnostic". This diagnostic could have a large value (a good model result) from both a large $R^{2}$ in the numerator, meaning a high correlation with observed anomalies, and a small rms difference in the denominator, implying a good fit. This tends to amplify differences between two model comparisons to the same data. An ideal model fit would correlate tightly in time to observed oscillations but also exhibit the right magnitude by "hugging" the anomaly series. Indeed, two model series could have oscillations in phase with data variations and the same $R^{2}$ values, but with different amplitudes and over- 
all fits; conversely, two model series could have different $R^{2}$ values versus observations, if one is more out of phase than the other, but they could still produce similar rms difference fits.

Figure 10 shows latitude-pressure contours of the above diagnostics for FR-WACCM and SD-WACCM O $\mathrm{O}_{3}$ anomalies in relation to MLS anomalies for 2005-2014. We see from Fig. 10a and $b$ that SD-WACCM rms difference diagnostic values (in the 0.2 to 1 range in the stratosphere) are smaller than those from FR-WACCM (between about 0.8 and 1.2). $R^{2}$ values, between about 0.7 and 0.95 in most of the stratosphere, show that SD-WACCM correlates very well with the observations; $R^{2}$ is somewhat smaller in the UTLS. The FR-WACCM $\mathrm{O}_{3}$ series correlate well with the data at low to midlatitudes for pressure levels between 70 and $7 \mathrm{hPa}$, which is also where the FR-WACCM rms difference diagnostic shows better performance and (as an explanation) where the dynamics are nudged (to tropical winds) in a similar way as for SD-WACCM. However, FR-WACCM shows almost zero correlation at high latitudes and in all of the uppermost stratosphere.

Figure 11 shows sample $\mathrm{O}_{3}$ series for the upper stratosphere (at $2.2 \mathrm{hPa}$ ) for $0-10^{\circ} \mathrm{N}$ as well as $40-50^{\circ} \mathrm{N}$. Although the tropical series show good correlations for both models versus data, some of the details in the observed semiannual peaks and the interplay between the $\mathrm{AO}, \mathrm{SAO}$, and the quasi-biennial oscillation are better followed by the SDWACCM curve. The differences in $\mathrm{O}_{3}$ amplitude and phase are more clearly displayed in Fig. 11c, showing deseasonalized anomalies. Diagnostic values provided in this panel show that SD-WACCM performs better than FR-WACCM, with a much larger $R^{2}$ value and a smaller rms difference diagnostic value and, hence, a much better combined diagnostic value. The same comments apply to Fig. $11 \mathrm{~b}$ and d, which showcase the NH midlatitudes at $2.2 \mathrm{hPa}$. In the highlatitude lower stratosphere, the poorer FR-WACCM results in Fig. 10 are generally caused by time series that are less in phase with polar winter and spring variations, as well as by more departures in variation magnitudes. Figure 10e and f amplify model differences, with combined diagnostic values mostly below 1 for FR-WACCM but between 1 and 3 in the SD-WACCM case. The more realistic dynamics in SD-WACCM allow for better SD-WACCM fits, as shown in Figs. 10 and 11. These plots also point to poor upper tropospheric results for both models (with SD-WACCM slightly better), although this is not the focus of this paper.

Figure 12 describes the same diagnostics as above but for model-data $\mathrm{H}_{2} \mathrm{O}$ comparisons and a top level at $0.01 \mathrm{hPa}$. Again, the diagnostics of fit are usually much better for SDWACCM, which yields $R^{2}$ values of 0.6 to 0.9 and rms difference diagnostic values below 1 for most of the stratosphere and lower mesosphere, and therefore better combined diagnostic results than FR-WACCM. The SD-WACCM diagnostics are poorest in the upper mesosphere and at high latitudes near $215 \mathrm{hPa}$. In the upper stratosphere and mesosphere, the
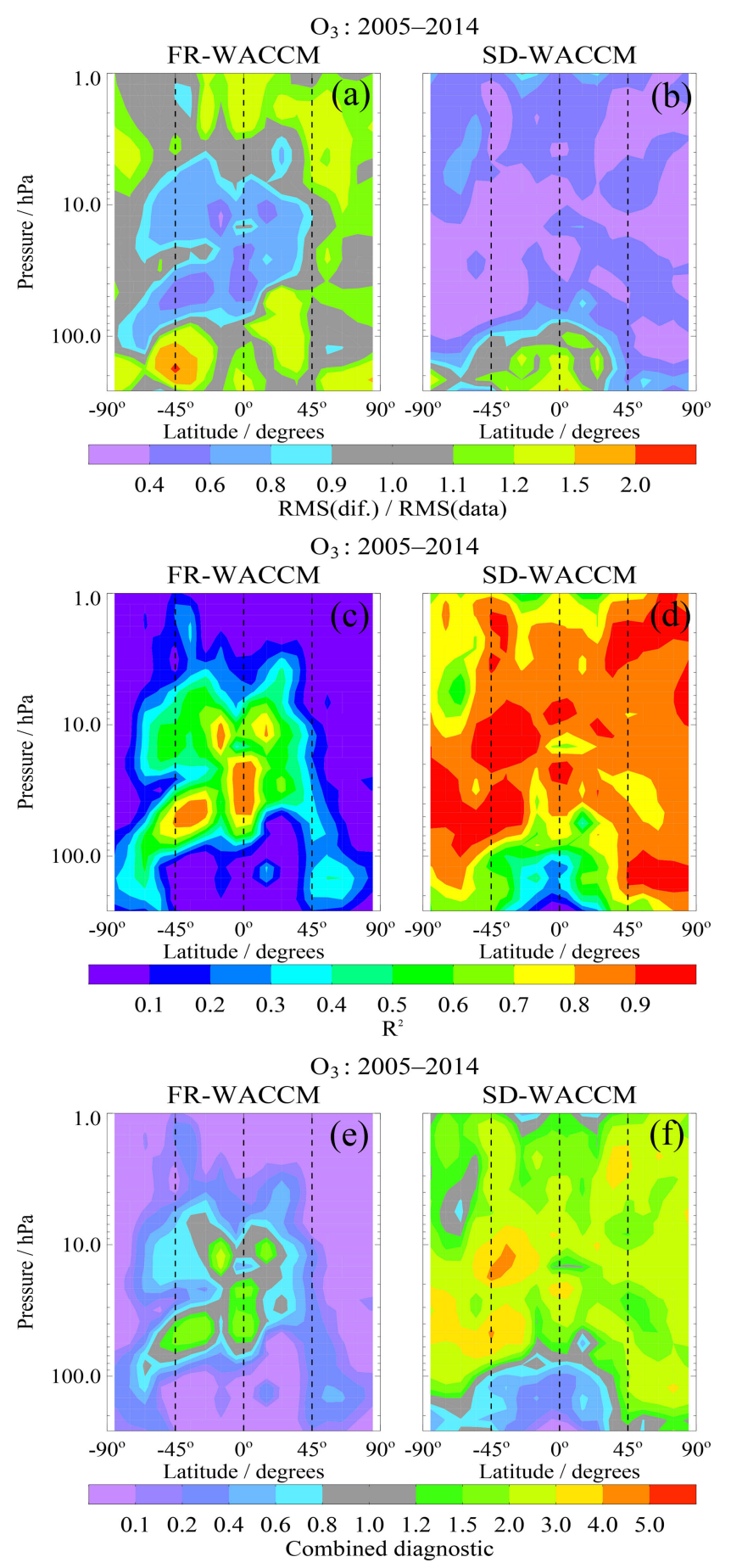

Figure 10. Latitude-pressure contours of diagnostics that show how well the deseasonalized anomalies of model ozone time series (FR-WACCM, a, c, e; SD-WACCM, b, d, f) compare to MLS O 3 anomaly series for 2005-2014. (a, b) show the rms difference diagnostic (see text) and (c, d) show $R^{2}$ values; small rms difference values represent a closer fit, while large $R^{2}$ values represent highly correlated results. $(\mathbf{e}, \mathbf{f})$ provide a combined diagnostic, namely the ratio of $R^{2}$ to the rms difference diagnostic from the top panels; larger values here represent a better result for comparisons to the observed time series. 

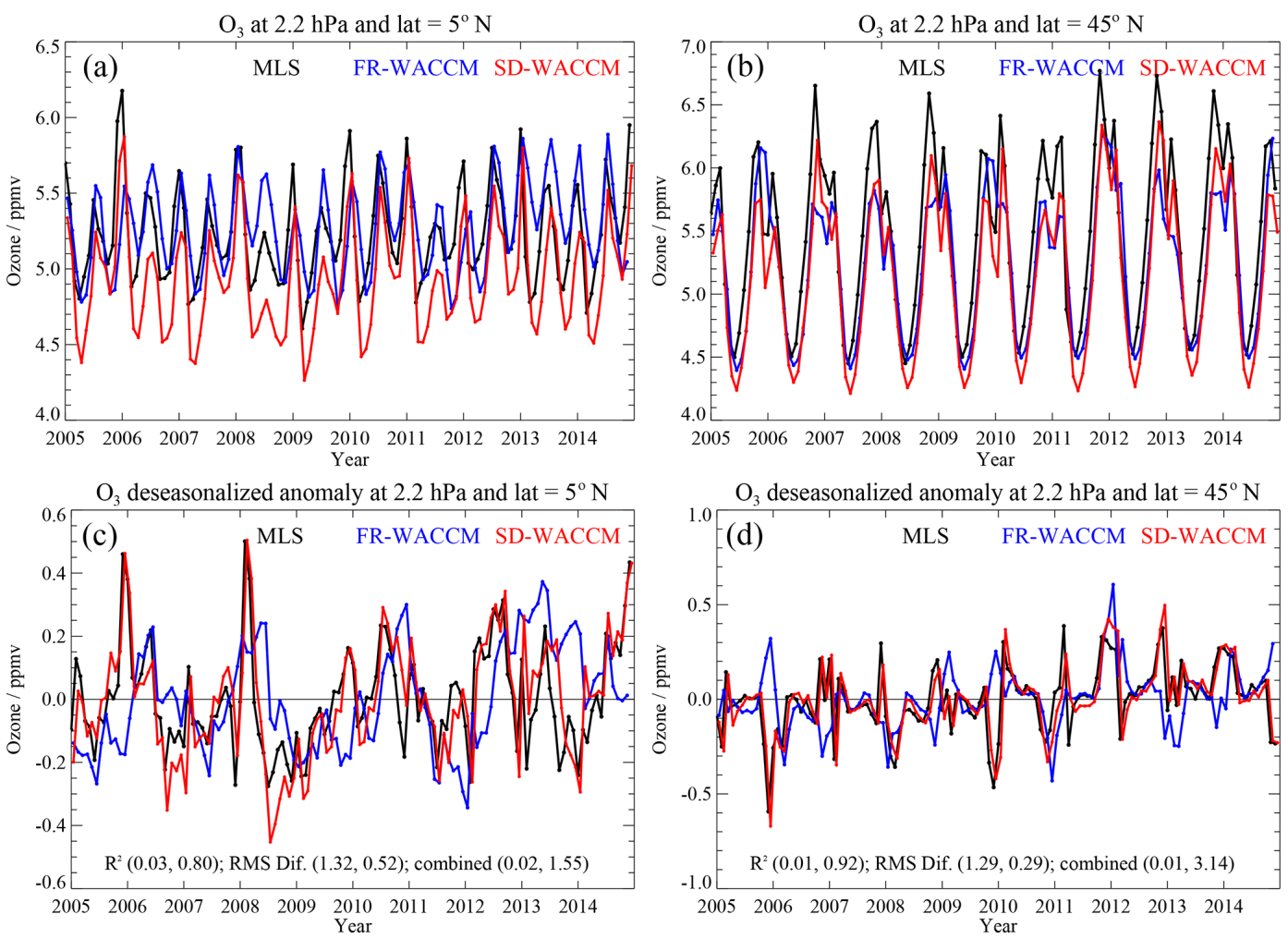

Figure 11. Time series of monthly zonal mean $\mathrm{O}_{3}$ mixing ratios at $2.2 \mathrm{hPa}(\mathbf{a}, \mathbf{b})$ and deseasonalized anomalies $(\mathbf{c}, \mathbf{d})$, with the $0-10^{\circ} \mathrm{N}$ and $40-50^{\circ} \mathrm{N}$ latitude bins on the left and right, respectively. The two model time series (FR-WACCM in blue and SD-WACCM in red) are compared to the MLS series (in black) for 2005-2014. Diagnostic values (see text for a description) are shown in parentheses in the bottom two panels $(\mathbf{c}, \mathbf{d})$, with the first number referring to FR-WACCM and the second number to SD-WACCM.

better diagnostic results for SD-WACCM are seen in time series (not shown) as a better match versus the MLS $\mathrm{H}_{2} \mathrm{O}$ anomalies in terms of the interannual variability at all latitudes, as well as for some seasonal peaks at high latitudes. We interpret this as the result of a better dynamical representation of the mesosphere for SD-WACCM. The highquality representation of mesospheric composition by SDWACCM is also demonstrated in comparisons to measurements of CO profiles above Kiruna, Sweden, by MLS and the Kiruna Microwave Radiometer (Ryan et al., 2018). For $\mathrm{H}_{2} \mathrm{O}$ near $200 \mathrm{hPa}$, poor fits at high latitudes occur where MLS data exhibit a dry bias versus sonde and Atmospheric Infrared Sounder (AIRS) data, as discussed in MLS data documentation (Livesey et al., 2018), as well as by Vömel et al. (2007) and Davis et al. (2016). MLS $\mathrm{H}_{2} \mathrm{O}$ is low by a factor of several here versus the WACCM runs (which show values of 10-60 ppmv). The data variability may also be affected by the dry bias retrieval (and oscillation) issues at the lowest altitudes at high latitudes, where observed anomalies are more poorly tracked by the models; a planned future update to the $\mathrm{MLS}_{2} \mathrm{O}$ retrievals will help to mitigate this discrepancy.

Figure S8 displays results similar to Fig. 10 but for stratospheric $\mathrm{HCl}$. SD-WACCM $\mathrm{HCl}$ results versus MLS are supe- rior to those from FR-WACCM and show high correlations $\left(R^{2}>0.7\right)$ in most of the lower stratosphere, with somewhat poorer results in the upper stratosphere, where the rms difference fits and the combined diagnostic are poor for both models. This upper-stratospheric issue is caused by a data problem in this region, where MLS $\mathrm{HCl}$ trends are known to be too flat (close to zero). Poorer correlations are observed for FR-WACCM at high latitudes, but even subtle differences in the timing (phase) can lead to poorer correlations. Poorer fits at $100 \mathrm{hPa}$ in the deep tropics are related to a large underestimate of the data, which may be caused, in part, by a high bias from MLS (Froidevaux et al., 2008b) but more so, for $R^{2}$, by out-of-phase model variability.

For $\mathrm{N}_{2} \mathrm{O}$, we also observe in Fig. S9 (showing model comparisons to the 68 to $1 \mathrm{hPa}$ observations from the $190 \mathrm{GHz}$ MLS $\mathrm{N}_{2} \mathrm{O}$ band for 2005-2014) that SD-WACCM fits the data better than FR-WACCM, in both the $R^{2}$ and the rms difference categories. FR-WACCM exhibits poor results in the upper stratosphere and at high latitudes in the lower stratosphere. Both models exhibit poorer rms fits and poorer correlations in the tropical lower stratosphere. Partly, this appears to be caused by a model underestimation of the MLS $\mathrm{N}_{2} \mathrm{O}$ variability in this region, with some QBO phasing differences as well. 


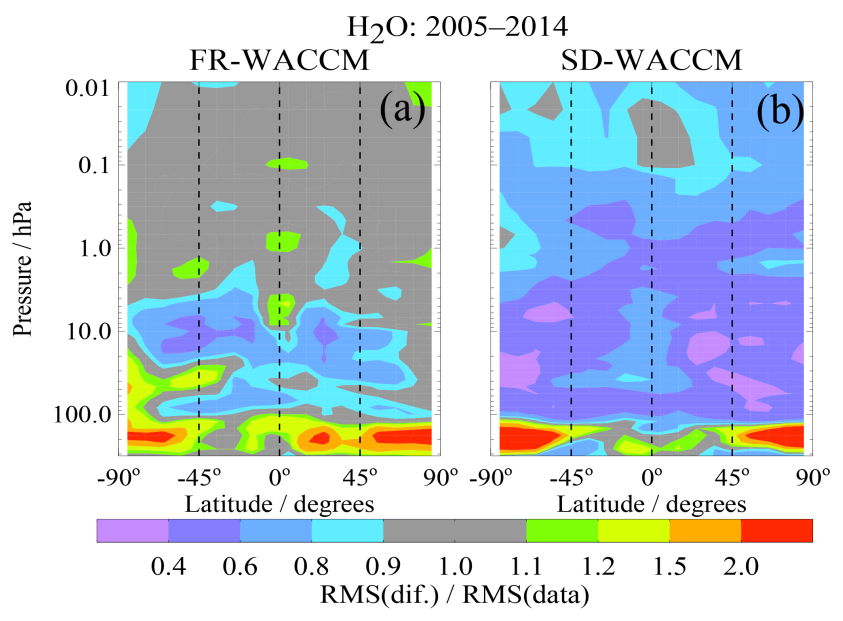

$\mathrm{H}_{2} \mathrm{O}: 2005-2014$

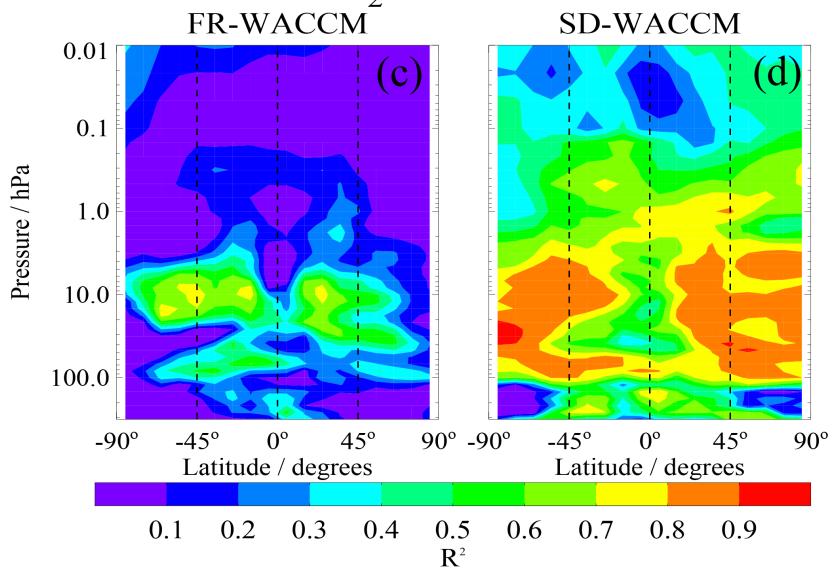

$\mathrm{H}_{2} \mathrm{O}: 2005-2014$

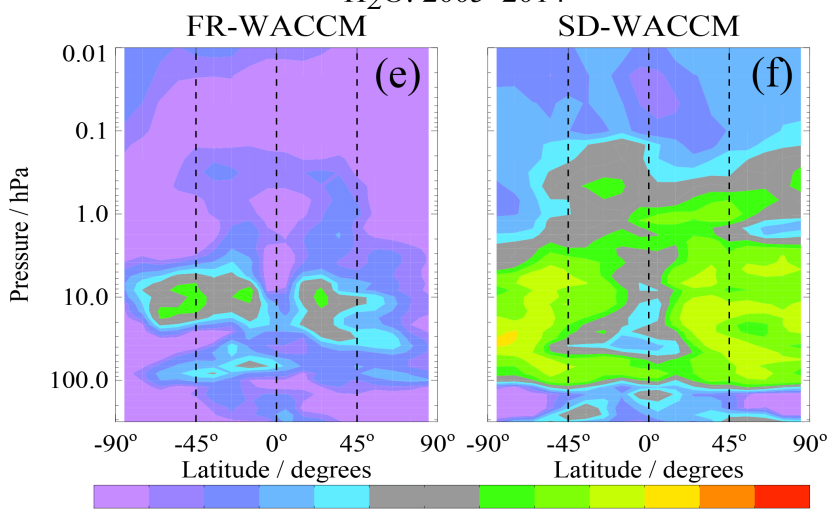

$\begin{array}{llllllllllll}0.1 & 0.2 & 0.4 & 0.6 & 0.8 & 1.0 & 1.2 & 1.5 & 2.0 & 3.0 & 4.0 & 5.0\end{array}$ Combined diagnostic

Figure 12. Same as the Fig. 10 diagnostics but for $\mathrm{H}_{2} \mathrm{O}$ up to $0.01 \mathrm{hPa}$.

$\mathrm{HNO}_{3}$ results (see Fig. S10) show, again, better fits to stratospheric MLS data from SD-WACCM than from FRWACCM and poor performance from FR-WACCM at high latitudes. Both models do poorly in the upper stratosphere, and Fig. 13 illustrates the magnitude of this discrepancy in the region $\left(3.2 \mathrm{hPa}\right.$ and $\left.70-80^{\circ} \mathrm{S}\right)$ where it reaches its max-

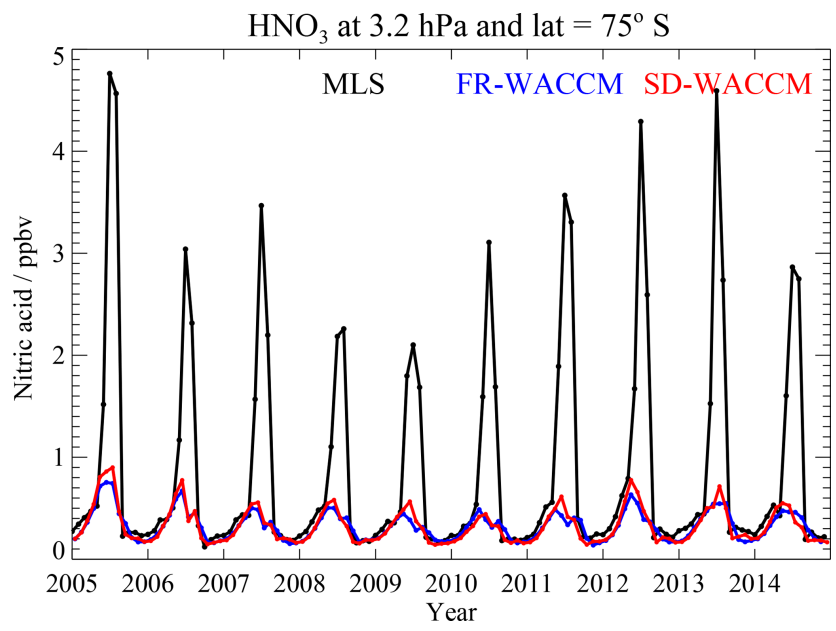

Figure 13. $\mathrm{HNO}_{3}$ monthly zonal mean mixing ratio time series (2005 through 2014) from MLS, FR-WACCM, and SD-WACCM for $3.2 \mathrm{hPa}$ and $70-80^{\circ} \mathrm{S}$.

imum. Since its launch, MLS has been observing very large values of $\mathrm{HNO}_{3}$ in the upper stratosphere, mostly in the polar regions during winter. The WACCM runs used here do not include the necessary photochemical pathways, including the effects of energetic particle precipitation on ion chemistry in the upper atmosphere, to adequately represent such variations; implementation of the necessary missing chemical reactions has not made its way into most CCMs. The solution seems tied to ion cluster chemistry during energetic particle precipitation (EPP) events, which includes large solar proton events (SPEs) as well as more regular auroral activity. Direct high-altitude EPP effects enhance $\mathrm{NO}_{x}$, which can propagate downward in polar winter and increase stratospheric $\mathrm{NO}_{x}$ and $\mathrm{HNO}_{3}$ via this indirect effect and conversion of $\mathrm{N}_{2} \mathrm{O}_{5}$ on ion water clusters (Böhringer et al., 1983). Large polar enhancements in upper-stratospheric $\mathrm{HNO}_{3}$ were observed by the MIPAS after SPE activity in 2003 (Orsolini et al., 2005; von Clarmann et al., 2005; Lopez-Puertas et al., 2005; Stiller et al., 2005). More complex modeling (e.g., Funke et al., 2011; Verronen et al., 2011; Kvissel et al., 2012; Andersson et al., 2016) has produced EPP-induced enhancements in high-latitude $\mathrm{HNO}_{3}$, with related improvements in model-data comparisons into the mesosphere. Regarding low-latitude upper-stratospheric $\mathrm{HNO}_{3}$, the poorer model fits seem to be caused at least in part by more noisy and variable MLS data, under low $\mathrm{HNO}_{3}$ conditions. Finally, tropical MLS $\mathrm{HNO}_{3}$ data at 147 and $215 \mathrm{hPa}$ are not fit well by either model, as the data exhibit seasonal oscillations between 0.2 and $0.5 \mathrm{ppbv}$, whereas model values are smaller than $0.1 \mathrm{ppbv}$. There have been few tropical UT validation comparisons for $\mathrm{HNO}_{3}$ (Santee et al., 2007), but in situ data from an airborne chemical ionization mass spectrometer have shown that UT $\mathrm{HNO}_{3}$ tropical values are mostly below $0.1-$ 0.2 ppbv (Popp et al., 2007, 2009). 
We saw in Sect. 4 that there are good climatological comparisons between SD-WACCM and MLS variations over Antarctica during polar winter and spring, except for the rate of $\mathrm{HCl}$ decline in early winter; also, poorer results are obtained by FR-WACCM. We also find, not too surprisingly, that interannual differences in lower-stratospheric chemical evolution over Antarctica are not as faithfully reproduced by FR-WACCM as by SD-WACCM. This is shown by the anomaly time series comparisons of Fig. $\mathrm{S} 11$ for $\mathrm{O}_{3}$ and temperature at $68 \mathrm{hPa}$ and $70-80^{\circ} \mathrm{S}$, along with the associated model diagnostic values. These plots also show that springtime anomalies dominate the variability, with warmerthan-usual springs (in October in particular), such as in 2012 and 2013, leading to more positive ozone anomalies, i.e., less ozone depletion; conversely, years $(2006,2008,2010,2011)$ with colder-than-usual springs are correlated with negative ozone anomalies and more depleted conditions.

\subsubsection{Variability}

Given our expectations that SD-WACCM would match observed time series of multiple species better than FRWACCM, and having demonstrated this in the previous section, we turn to what should be a more fair comparison between the two sets of model results, namely the variability aspect. We calculate the ratio of model to data interannual variability, as obtained from the root mean square values of deseasonalized monthly anomaly series, expressed as a percent of climatological means; a simple linear trend is first subtracted from the series, so that the variability comparisons remove any significant trend differences. We do this for the MLS data, but also for longer-term time series, using the GOZCARDS data. The models are sampled following the monthly sampling of the data sets (but not at the daily sampling level of detail); sampling plays a role for the longerterm (merged) GOZCARDS data, which are comprised of some unevenly sampled occultation data records (depending on latitude and pressure). Figure 14 compares the $\mathrm{O}_{3}$ variability ratios (models versus data) using as a reference the MLS 2005-2014 data (Fig. 14a and b) and the GOZCARDS merged ozone (1992-2003) data (Fig. 14c and d). To first order, we observe similar patterns for both time periods. The SD-WACCM variability is generally within $10 \%-20 \%$ of the data variability (ratio values between 0.8 and 1.2 ). The FR-WACCM variability is somewhat smaller than the data variability in the polar regions and in the upper stratosphere. Bandoro et al. (2018) also found that the free-running version of WACCM displays smaller ozone variability in the upper stratosphere, both for shorter-term and longer-term variabilities, than the observed variability, based on the merged SWOOSH O $\mathrm{O}_{3}$ data record. In the lower stratosphere at low to midlatitudes, FR-WACCM exhibits slightly larger variability than the data, whereas SD-WACCM shows slightly smaller variability than the data; Bandoro et al. (2018) found that FR-WACCM slightly overestimates the decadal variability
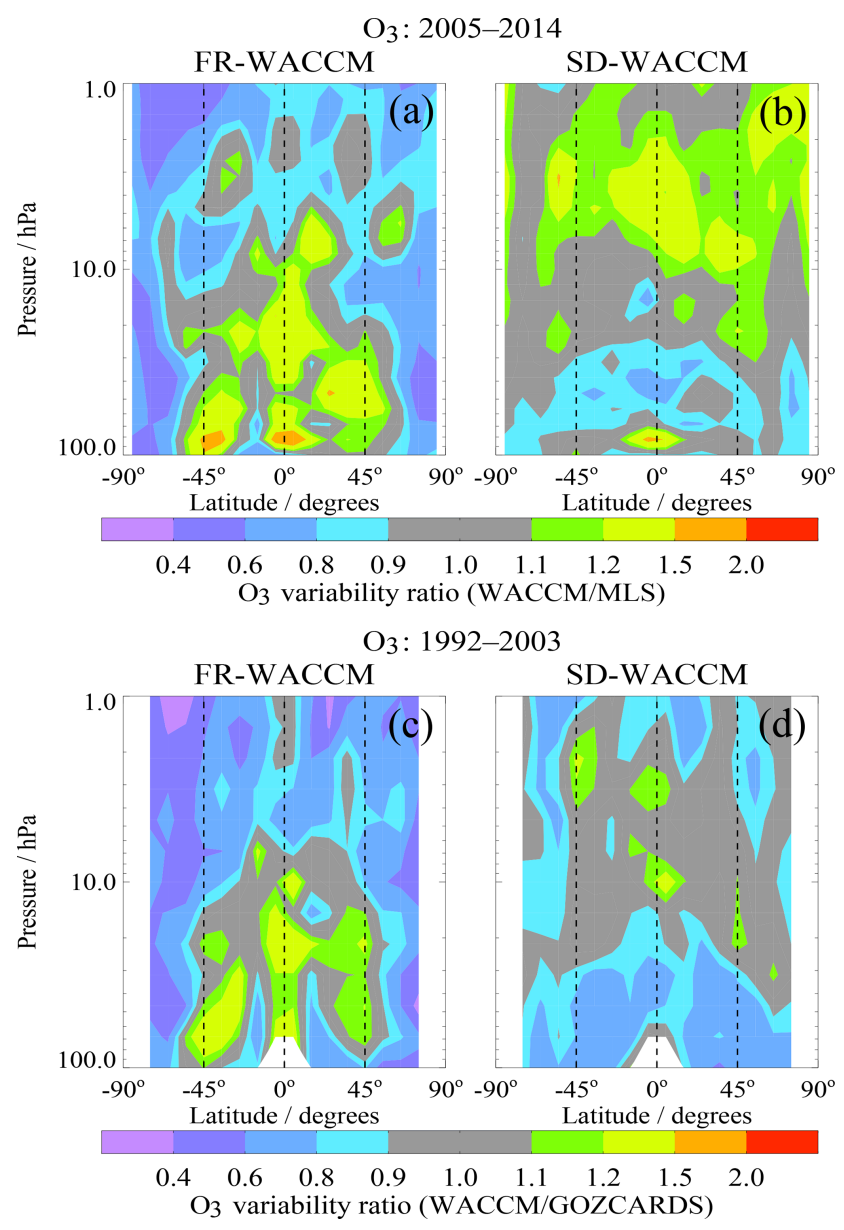

Figure 14. Variability ratios (model results divided by data results) for stratospheric $\mathrm{O}_{3}$, with FR-WACCM results on the left $(\mathbf{a}, \mathbf{c})$ and SD-WACCM on the right $(\mathbf{b}, \mathbf{d})$. Before calculating the ratios, the variability values are obtained as the root mean square of detrended deseasonalized monthly anomaly time series and expressed as a percentage of mean (climatological) abundances; (a, b) show comparisons to MLS data for 2005-2014, whereas (c, d) are for 1992-2003 comparisons to GOZCARDS.

in this region. We also see in Fig. 14 that, at high latitudes, FR-WACCM underestimates the actual variability, whereas this is less of an issue for SD-WACCM, with its more realistic representation of the dynamics; as an example, refer to Fig. 13 for model and data anomalies at $68 \mathrm{hPa}$ and $70-80^{\circ} \mathrm{S}$.

A similar overview of model/data variability ratios is provided for $\mathrm{H}_{2} \mathrm{O}$ in Fig. 15, for the mesosphere and the stratosphere. Here, while the variability from SD-WACCM is closer than that from FR-WACCM to the data variability during both periods, the tendency for both models is to underestimate the observed variability, with FR-WACCM showing a stronger underestimate in the upper stratosphere and mesosphere. Such an underestimate for FR-WACCM implies that a trend detection in the future will require more years of data, if $\mathrm{H}_{2} \mathrm{O}$ continues to have larger variability than models. 

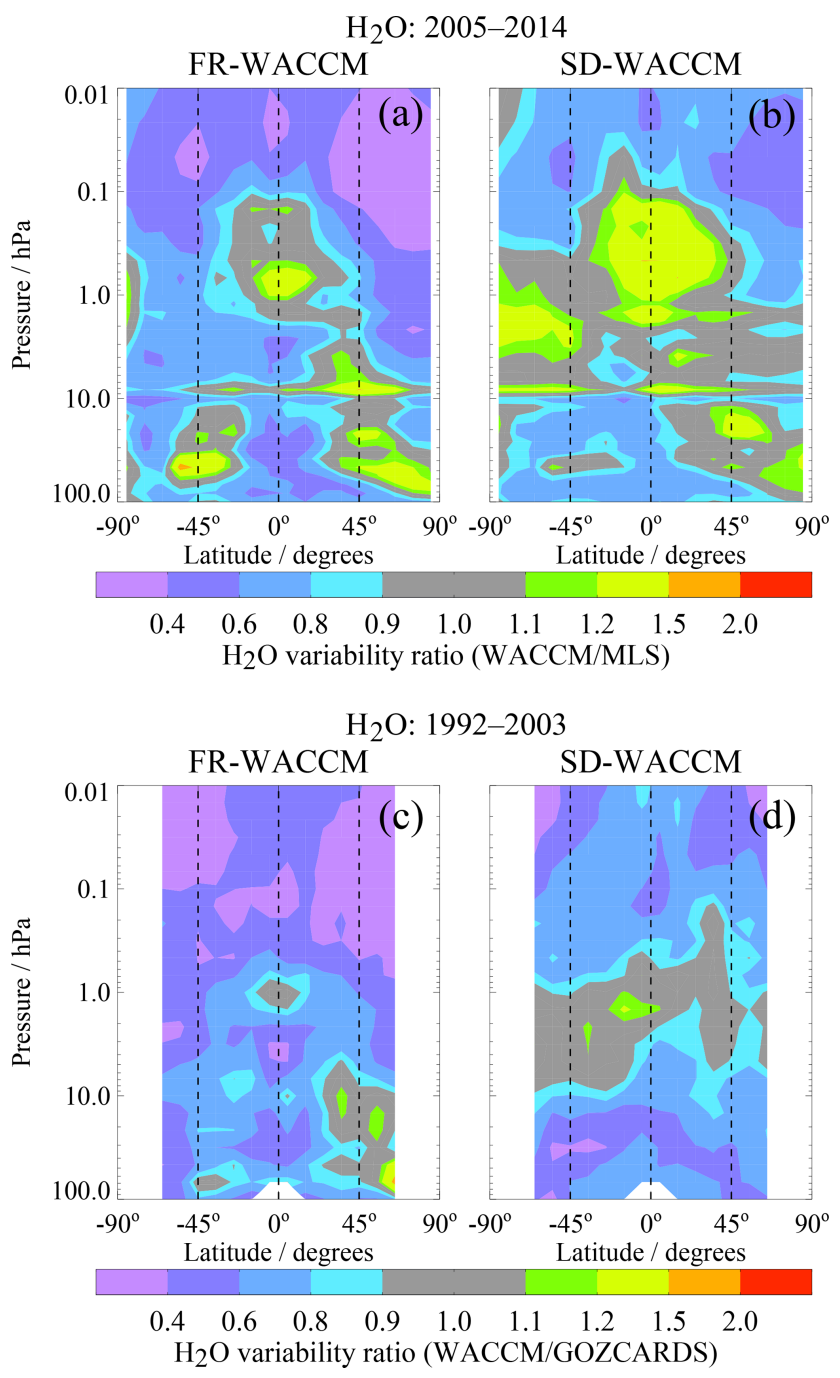

Figure 15. Same as Fig. 14 but for ratios (model/data) of $\mathrm{H}_{2} \mathrm{O}$ stratospheric and mesospheric variability for two different time periods.

The FR-WACCM underestimate of the variability is sometimes by as much as a factor of 2, although it is more typically by $\sim 30 \%$ (see Fig. 15). For a series with rms variability about the fit represented by $\sigma_{t}$, the number of years needed to statistically detect a trend is proportional to $\sigma_{t}^{2 / 3}$ (Weatherhead et al., 1998), and thus an increase of $\sigma_{t}$ by factors of 1.3, 1.5, and 2.0, for example, will lead to an increase in the number of years for trend detection by factors close to $1.2,1.3$, and 1.6, respectively. In the tropical lowerstratospheric case, $\mathrm{H}_{2} \mathrm{O}$ and temperature values and anomalies for $1992-2014$ are shown for $100 \mathrm{hPa}$ and $10-20^{\circ} \mathrm{S}$ in Fig. 16. Again, we note the smaller-than-observed variability in model $\mathrm{H}_{2} \mathrm{O}$ oscillations, with SD-WACCM tracking the data better. This correlates with the temperature series, where smaller variability is seen in FR-WACCM, in comparison to SD-WACCM (which follows MERRA temperatures); we also note that FR-WACCM temperatures are somewhat larger (by $\sim 1 \mathrm{~K}$ on average) than SD-WACCM temperatures in this region. This poorer tracking of cold point temperatures for FR-WACCM (Fig. 16) has likely implications for poorer stratospheric trend results for FR-WACCM $\mathrm{H}_{2} \mathrm{O}$ as well, as we will actually observe in the trends section (Sect. 5.2). It is well known that stratospheric entry level $\mathrm{H}_{2} \mathrm{O}$ is governed by temperatures near the tropopause cold trap; the monthly average variations shown here are similar to what has been shown in past $\mathrm{H}_{2} \mathrm{O}$ work (e.g., Randel et al., 2004, 2006; Randel and Jensen, 2013). Brinkop et al. (2016) used model runs from both free-running and nudged simulations to analyze the impacts of different constraints, including sea surface temperatures (SSTs) and meteorological fields, on sudden drops in $\mathrm{H}_{2} \mathrm{O}$; they found that several of these factors play a role in the $\mathrm{H}_{2} \mathrm{O}$ variations, including the timing of El Niño-Southern Oscillation (ENSO) and SST variability, the phasing with the QBO, cold point temperatures, and the correct dynamical model state. Many other analyses of the relation between entry level $\mathrm{H}_{2} \mathrm{O}$, tropopause temperatures, transport, and convection have been carried out previously (e.g., Holton and Gettelman, 2001; Jensen and Pfister, 2004; Fueglistaler and Haynes, 2005; Rosenlof and Reid, 2008; Read et al., 2008; Schoeberl et al., 2013). Our point here is that the WACCM $\mathrm{H}_{2} \mathrm{O}$ anomaly series underestimate the observed variability. We note also that this model underestimate exists if we calculate relative variability using a maximum minus minimum range from yearly average anomalies rather than monthly averages. We provide a global view of lowerstratospheric variability differences (models versus data) in the anomaly series comparisons at $83 \mathrm{hPa}$ for all latitude bins in Fig. S12. This also shows that the observed interannual changes in $\mathrm{H}_{2} \mathrm{O}$ are better followed by SD-WACCM than by FR-WACCM, including the drop in $\mathrm{H}_{2} \mathrm{O}$ after 2011 (see Urban et al., 2014). While lower-stratospheric $\mathrm{H}_{2} \mathrm{O}$ variability is underestimated by SD-WACCM by $\sim 20 \%$, the correlation between SD-WACCM and observed anomalies is very good (as was shown in Fig. 12).

For $\mathrm{HCl}$, we show the (detrended) variability ratios in Fig. 17. The observed $\mathrm{HCl}$ variability is fairly well matched (within $\sim 20 \%$ ) by both models in the MLS time period, with an edge given to SD-WACCM. The observed variability is often underestimated (by $\sim 30 \%$ ) by both FR-WACCM and SD-WACCM in the earlier period (1992-2003). We believe that the HALOE sampling plays a role in this; i.e., even if we limit the model comparison (as we do here) to just the same months as when HALOE observations occurred, incomplete sampling in latitude and time can lead to differences versus a fully sampled model (see Toohey et al., 2013) and more so in the polar regions where the $\mathrm{HCl}$ variability is large. In the upper stratosphere, the variability ratios are comparable to or somewhat smaller than those in the middle stratosphere, and there is a $20 \%-30 \%$ underestimate of the observed variability, which is based on HALOE $\mathrm{HCl}$ observations for 1992-2003. There have been difficulties in fully 

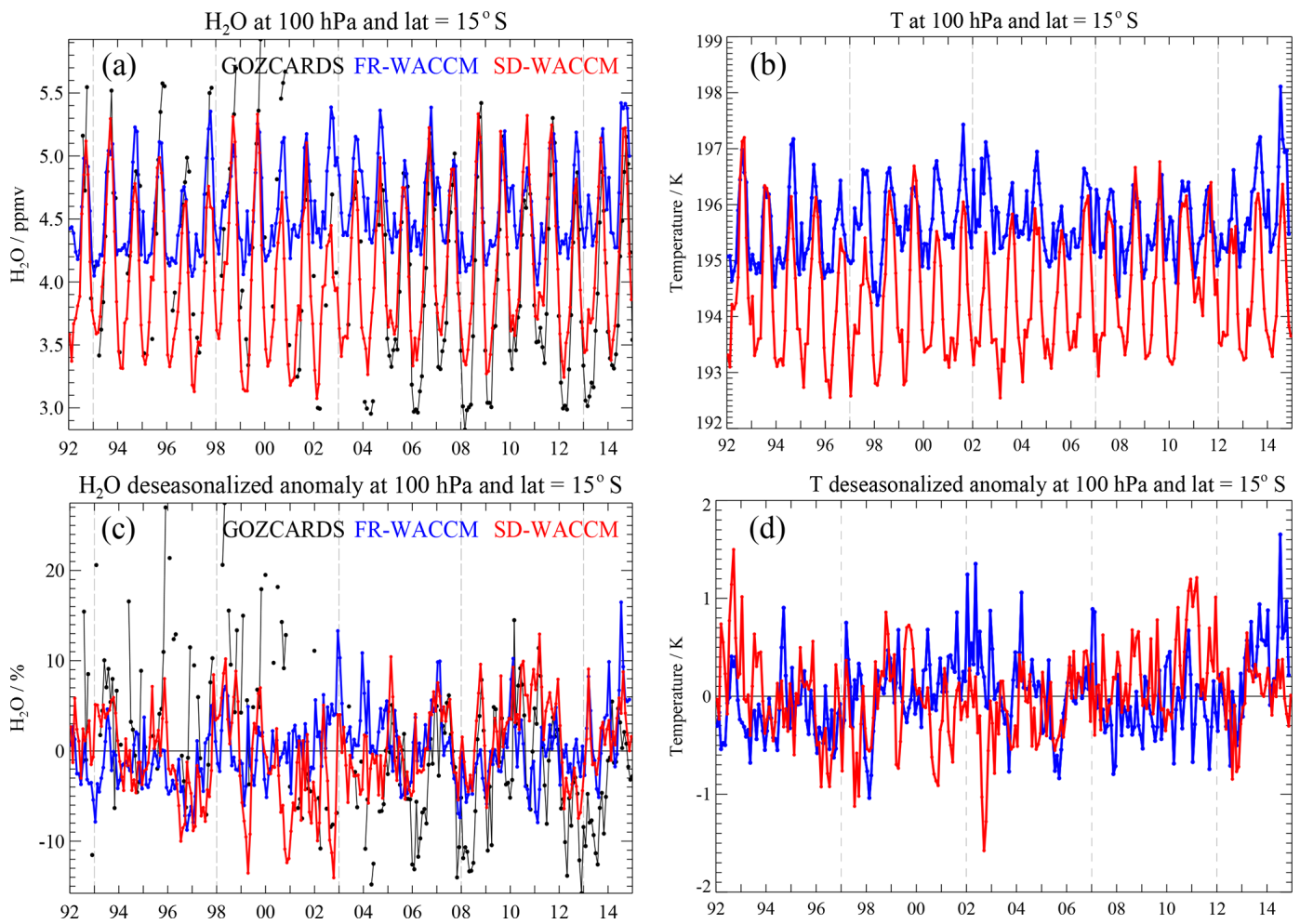

Figure 16. Time series (1992-2014) at $100 \mathrm{hPa}$ and $10-20^{\circ} \mathrm{S}$ for temperature (b, d) and $\mathrm{H}_{2} \mathrm{O}(\mathbf{a}$, c), with deseasonalized anomalies shown in (c, d). The temperature plots just show the two models (FR-WACCM in blue, SD-WACCM in red), whereas the $\mathrm{H}_{2} \mathrm{O}$ series show the comparisons for the models versus GOZCARDS merged $\mathrm{H}_{2} \mathrm{O}$ data (in black).

understanding (or modeling) observed upper-stratospheric $\mathrm{HCl}$ variations before the declining phase that started after about 2000 (Waugh et al., 2001); see also Sect. 5. For 20052014, SD-WACCM actually matches the upper-stratospheric MLS variability fairly well, although these variability values are small.

We also show the ratios of model to data variability for stratospheric $\mathrm{HNO}_{3}$ (2005-2014) and $\mathrm{N}_{2} \mathrm{O}$ (2005-2012) in Fig. S13. We already discussed the issues with missing model chemistry for upper-stratospheric $\mathrm{HNO}_{3}$ variability, as well as the low signal-to-noise issue for $\mathrm{HNO}_{3}$ data at low latitudes in this region. There is reasonably good agreement in the $\mathrm{HNO}_{3}$ variability between SD-WACCM and MLS for the lower to mid-stratosphere, while FR-WACCM generally overestimates the $\mathrm{HNO}_{3}$ variability in this region. Figure S13 shows $\mathrm{N}_{2} \mathrm{O}$ results down to $100 \mathrm{hPa}$. Here, MLS $\mathrm{N}_{2} \mathrm{O}-640$ data (from the $640 \mathrm{GHz}$ radiometer) for 2005-2012 are used; these retrievals were curtailed in the first half of 2013 as a result of degradation in the $640 \mathrm{GHz}$ radiometer signal chain. Based on results shown in SPARC (2017), there appears to be good agreement in the tropical interannual variability comparisons for $\mathrm{N}_{2} \mathrm{O}$ at $100 \mathrm{hPa}$ between MLS and other satellite-derived results. The lower-stratospheric $\mathrm{N}_{2} \mathrm{O}$ time series behave more smoothly at low latitudes in the models than in the observations. The interannual variability in the MLS $\mathrm{N}_{2} \mathrm{O}$ measurements there is somewhat smaller than the standard deviations in monthly mean $\mathrm{N}_{2} \mathrm{O}$ values (of 20-30 ppbv). The MLS $\mathrm{N}_{2} \mathrm{O}$ measurement noise itself for a monthly zonal mean (made up of about 5000-6000 profiles) should be less than $1 \mathrm{ppbv}$. Smoothing the model in the vertical domain to better match the MLS vertical resolution would not lead to a better fit to the observed variability. However, we should keep in mind that the MLS-derived $\mathrm{N}_{2} \mathrm{O}$ variability is a small percentage $(<3 \%)$ of the monthly zonal mean $\mathrm{N}_{2} \mathrm{O}$ abundances. In summary, SD-WACCM shows some underestimate of the observed lower-stratospheric tropical variability for all the species considered here, except for $\mathrm{HNO}_{3}$; FR-WACCM does so also for three species $\left(\mathrm{H}_{2} \mathrm{O}, \mathrm{HCl}\right.$, and $\mathrm{N}_{2} \mathrm{O}$ ). It may be that some of the larger variability in the measurements arises from effects not tied just to MLS radiance noise issues, or from variability caused by the proximity to the tropopause for measurements with finite vertical resolution; WACCM could also be genuinely underestimating the actual atmospheric variability near the tropopause (for unknown reasons).

\subsection{Trends}

In this section, we discuss how the WACCM runs compare to stratospheric observations when it comes to trends, from fairly short-term trends (from the Aura MLS time period) to 

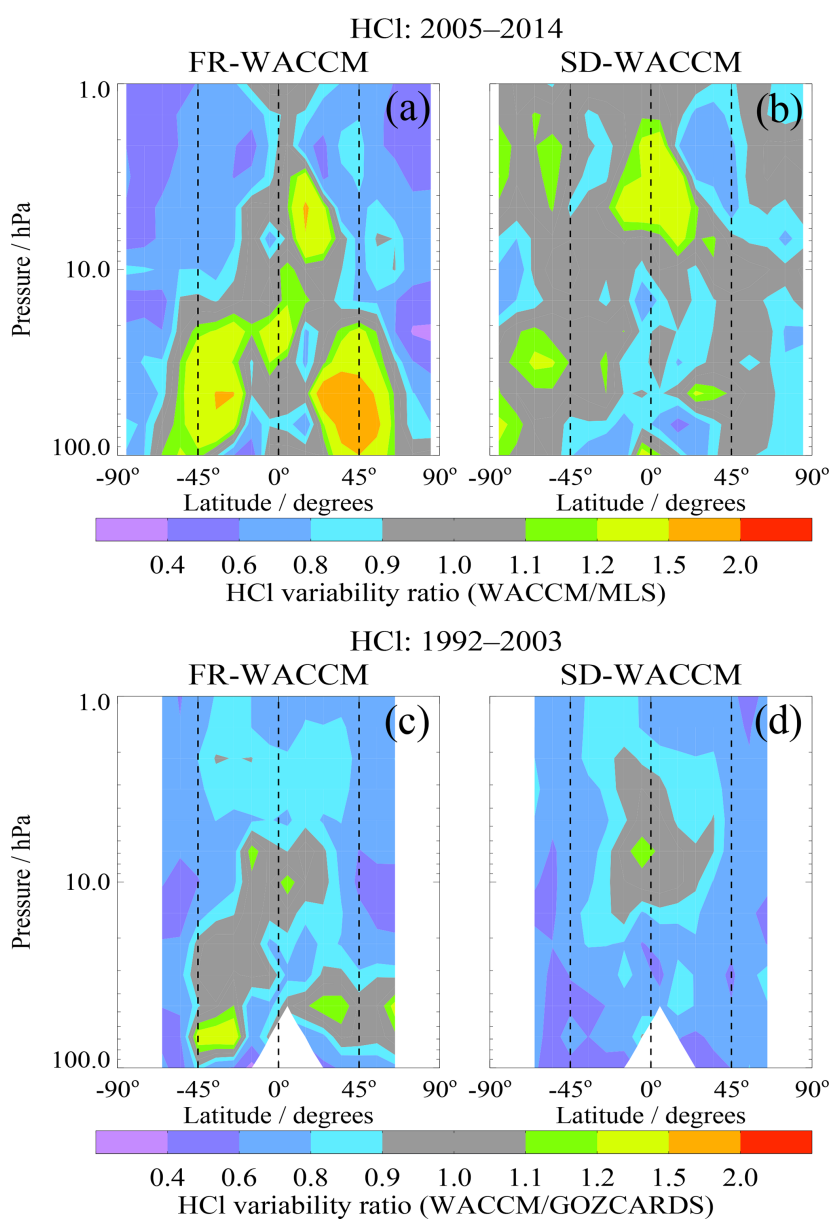

Figure 17. Same as Fig. 14 but for ratios (model/data) of $\mathrm{HCl}$ stratospheric variability.

longer-term trends based on comparisons with $\mathrm{O}_{3}, \mathrm{H}_{2} \mathrm{O}$, and $\mathrm{HCl}$ GOZCARDS data records (see Sect. 2 and Froidevaux et al., 2015). Trend analyses have their own complexities in terms of analysis methods and uncertainty estimates. For example, $\mathrm{O}_{3}$ trend assessments have had to deal with trend estimates from different long-term data records, each with its own characteristics (Tummon et al., 2015; WMO, 2014; Harris et al., 2015; Steinbrecht et al., 2017; Ball et al., 2017, 2018). This kind of analysis is especially difficult when investigating trends from time series with high variability compared to the size of an underlying long-term change over time, which is certainly an issue for the lower stratosphere. Also, global modeling efforts have led to improved characterizations of the expected combined and separate impacts on ozone profiles of long-term changes in halogen source gases and greenhouse gases (WMO, 2014).

Here, we focus mostly on trend results from WACCM and observations, given the application of the same analysis methods for the different series. We have applied multiple (or multivariate) linear regression (MLR) to the time series of deseasonalized anomalies from the data, FR-WACCM, and SD-WACCM. In Appendix A3, we provide more details regarding the regression model, which includes commonly used additive functional terms, including constant, linear, and periodic terms, along with proxies describing wellknown variations arising from the QBO and ENSO, as well as an 11-year solar cycle proxy term. Examples of observational time series from merged ozone observations for 1998 through 2014 are provided in Fig. A3, along with the fits to the series and the linear components (trends). We also discuss our methodology (a block bootstrap method) for trend error evaluations in Appendix A3; such an approach was used, for example, by Bourassa et al. (2014) for their trend analyses of ozone from the OSIRIS (Optical Spectrograph and Infrared Imager System) retrievals. We display the resulting trend error bars as $2 \sigma$ values (which is very close to the $95 \%$ bounds on the distribution of trend results). Such calculations often lead to significantly larger error bars than more standard methods or code (which neglect the autocorrelation of the residuals).

For ozone, we give an overview in Fig. 18 of percent deseasonalized anomaly time series for three latitude bins (northern midlatitudes, tropics, and southern midlatitudes) and two pressure levels $(3.2 \mathrm{hPa}$ for upper stratosphere, $68 \mathrm{hPa}$ for lower stratosphere). The series were deseasonalized in $10^{\circ}$ latitude bins and then averaged. The GOZCARDS data used here (version 2.20) are an update to the original (version 1.01) record (Froidevaux et al., 2015), as mentioned in Sect. 2. Figure 18 shows generally good agreement between the various time series, although if one looks carefully, SD-WACCM is generally closer to the observational time series than FR-WACCM is, as one might expect from previous considerations of goodness of fit and variability; also, percent variability is larger in the lower stratosphere than in the upper stratosphere, thus rendering trend detection more difficult at lower altitudes. We compare in Fig. 19 the ozone profile trend results from MLS data alone, from 2005 through 2014, to those from FR-WACCM and SD-WACCM, for the three aforementioned latitude bins. We show the error bars as $2 \sigma$ estimates, as this provides an easy way to visualize if there are significant differences between models and data, or between models. Furthermore, we have also shown (in grey) the data trend results for time series through the end of 2018, as a timely reference, but with no corresponding available model results. Trend results through 2018 also help to underscore how trend variability depends on the number of years used in the analyses. For ozone, this shows that there are certainly some altitude and latitude regions where the slightly longer-term trends differ from the shorter-term trends by as much as $0.2 \% \mathrm{yr}^{-1}$ (a typical $2 \sigma$ uncertainty), and especially at northern midlatitudes in the lowest altitude region, where a significant decrease in trend values is obtained (from 0.5 to $0.9 \% \mathrm{yr}^{-1}$ to near zero for the longer-term trend). In contrast, the southern midlatitudes show that the longer-term trends are positive throughout the stratosphere, whereas slightly negative values were obtained 

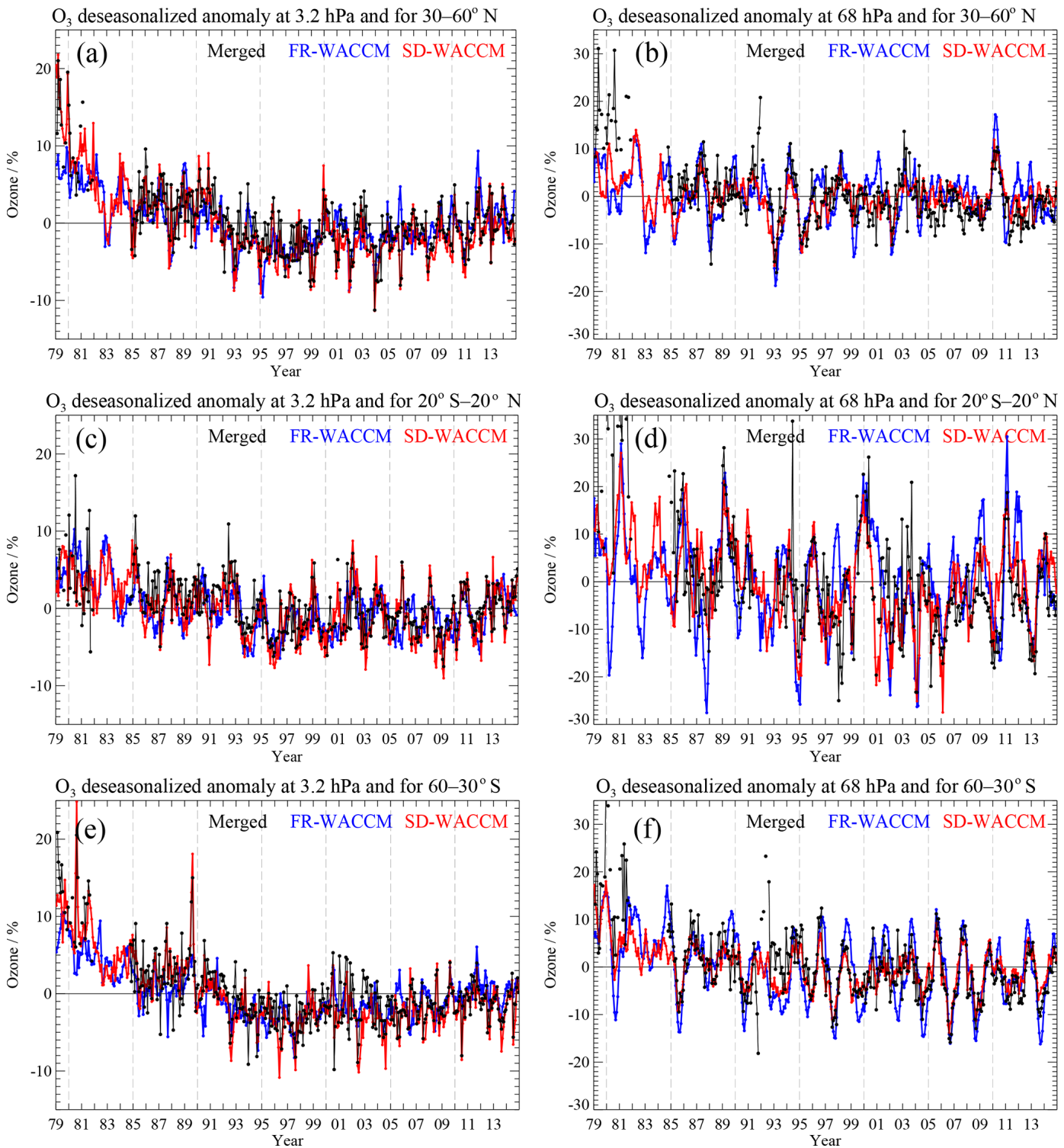

Figure 18. Sample time series of deseasonalized ozone anomalies (\%) from 1979 through 2014 from the GOZCARDS data record (version 2.20) compared to the corresponding model anomalies from FR-WACCM (blue) and SD-WACCM (red). Upper-stratospheric series at $3.2 \mathrm{hPa}$ are shown in (a, c, e) and lower-stratospheric series at $68 \mathrm{hPa}$ in $(\mathbf{b}, \mathbf{d}, \mathbf{f})$; three latitude bins are displayed $\left(30-60^{\circ} \mathrm{N}, \mathbf{a}, \mathbf{b} ; 20^{\circ} \mathrm{S}-20^{\circ} \mathrm{N}, \mathbf{c}, \mathbf{d}\right.$; and $30-60^{\circ} \mathrm{S}, \mathbf{e , f}$ ).

for 2005-2014. These changes can be traced back to ozone variability in the observational record; this underscores that large dynamical variability in the lower stratosphere will continue to create significant variability in the trends. Indeed, the importance of meteorological variability was recently emphasized by Chipperfield et al. (2018), who included MLS data through the end of 2017 in their comparisons to simulations from a chemical transport model; they showed that the MLS data exhibited large increases in the SH lower stratosphere in 2017, which led to a positive tendency for 20052017 trends in that region, in contrast to slight declines (or near-zero trends) in the $\mathrm{NH}$, in general agreement with the results shown here, which include one more year (2018) of MLS data. Moreover, Fig. 19 provides a robust indication from the MLS data alone that upper-stratospheric ozone values have been on the upswing in the past decade, at a rate of about 0.1 to $0.3 \% \mathrm{yr}^{-1}$, depending on latitude-altitude region, with $2 \sigma$ uncertainties of $\sim 0.2 \% \mathrm{yr}^{-1}$. While these $2 \sigma$ error bars (obtained using the bootstrap method mentioned earlier) are fairly large, there are several latitude regions and pressure levels with similar results, and this positive trend is a robust near-global upper-stratospheric result (with even smaller uncertainties). These results are broadly consistent with $\mathrm{O}_{3}$ trends obtained by Steinbrecht et al. (2017), who 
use MLS as part of the longer-term merged data records, although they studied a longer time period (2000-2016). All things being equal, the errors in these trends should diminish as more years of data are added to the $\mathrm{MLS} \mathrm{O}_{3}$ record, which, for the middle and upper stratosphere, has been characterized as "very stable", namely within 0.1 to $0.2 \% \mathrm{yr}^{-1}$ versus sonde and lidar network ozone data (Hubert et al., 2016); it seems difficult to quantify "absolute stability" to much better than this, especially in the lower stratosphere. In the lower stratosphere, trend results are closer to zero, with larger variability and error bars (in $\% \mathrm{yr}^{-1}$ ), and unambiguous detection of post-1997 ozone trends in this region remains elusive (WMO, 2014; Harris et al., 2015). The 2005-2014 trends in Fig. 19 show good broad agreement between model and data, with a tendency for SD-WACCM to agree better than FR-WACCM with MLS, albeit not significantly so, given the size of the error bars, especially in the lower stratosphere. The lower-stratospheric tropical results from FR-WACCM are negative, in contrast to both the observations and SD-WACCM, but with large error bars. In the tropical upper stratosphere, both models exhibit a somewhat more positive trend than observed for this period, with FR-WACCM diverging more from the observations than SDWACCM does. We do find it rather striking that, as a function of latitude (in $10^{\circ}$ wide bins) and pressure, the 2005-2014 SD-WACCM $\mathrm{O}_{3}$ trends follow the MLS trend results quite well; this is clearly shown in Fig. 20 for central latitudes from $55^{\circ} \mathrm{S}$ to $55^{\circ} \mathrm{N}$. As mentioned above (but not shown in Fig. 20), the agreement in these patterns is not as good for FR-WACCM.

For a consideration of longer time periods, we compare in Fig. 21 trends from the merged $\mathrm{O}_{3}$ GOZCARDS record (version 2.20) to model results for two time periods: Fig. 21a, c, and e for 1985-1997 focus on the main declining ozone phase, while Fig. 21b, d, and f show the post-1998 early ozone recovery stages. The largest differences between the two GOZCARDS data versions occur in the tropical upper stratosphere for the declining ozone phase; Fig. S14 displays the tropical trend differences that we obtain for the same three periods as in Fig. 19. In agreement with this are the trend differences provided by Ball et al. (2017), who showed results for the original (version 1.01) GOZCARDS data and for SWOOSH. GOZCARDS version 2.20 data are now in better agreement with the merged $\mathrm{SWOOSH} \mathrm{O} \mathrm{O}_{3}$ product (as both use SAGE II version 7 data); also, Steinbrecht et al. (2017) showed that these two merged records lead to similar (post-2000) trend results. The improvements in GOZCARDS version 2.20 ozone are a result of the incorporation of the SAGE II v7 retrievals (Damadeo et al., 2013) and the use of the MERRA temperatures (used in v7) for the conversion from density-altitude to the GOZCARDS mixing-ratiopressure grid. We note, however, that the lower-stratospheric region exhibits interannual variability that is several times larger than that in the upper stratosphere, as seen in Fig. A3 for tropical 1998-2014 data versus SD-WACCM. Even fairly

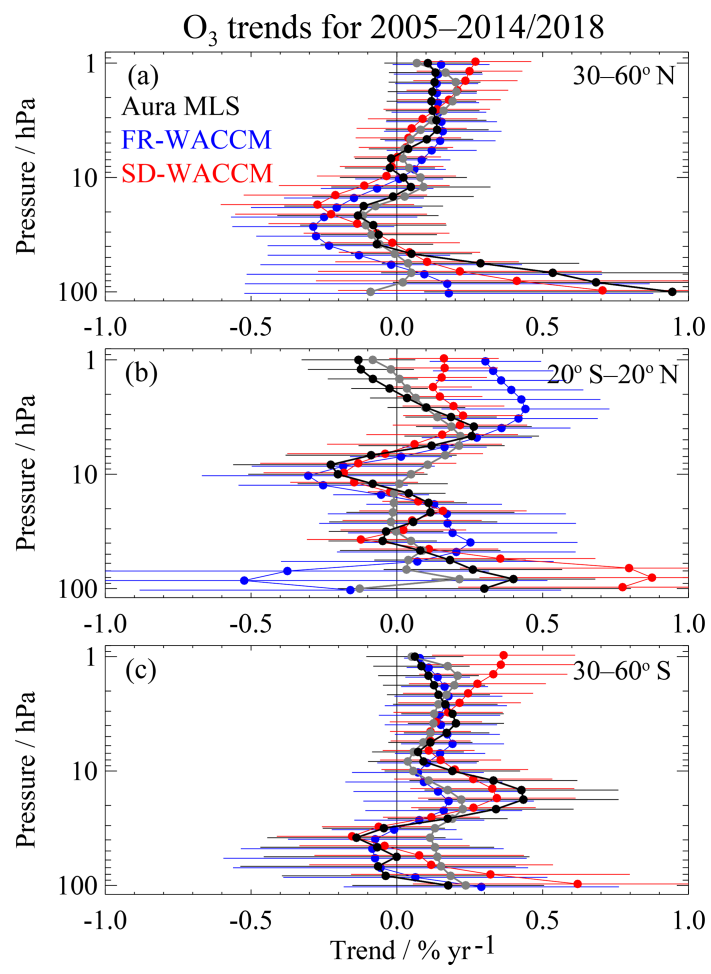

Figure 19. Ozone stratospheric trends for 2005 through 2014 obtained from monthly zonal mean data (version 4.2 Aura MLS) and models (FR-WACCM and SD-WACCM), after multiple linear regression analyses of deseasonalized anomaly time series, as described in the text. Each panel refers to results from different latitude band average series (see legend). The error bars are $2 \sigma$ estimates based on bootstrap resampling results (see text). We also show the data trends for 2005-2018 (in grey) to provide an update on how the past 4 years change the (slightly longer-term) tendencies; to avoid more clutter in these plots, we have not overplotted the corresponding error bars, but these are only slightly smaller than the black observational error bars.

subtle differences in time series over a few years can lead to a sign change in the trends, although there is no statistical significance in the resulting trend differences. For the pre-1998 period, Fig. 21 shows generally good agreement in the trends versus the models; FR-WACCM tends to fit the observed trends more poorly than SD-WACCM in the lower stratosphere, although the upper-stratospheric results at midlatitudes are somewhat poorer for SD-WACCM. The longer-term trends for 1998-2018 based on GOZCARDS data show slightly more positive trends than the 1998-2014 results, and the recent ozone changes that affected the results in Fig. 19 (with a 2005 starting year) are diluted somewhat for the period starting in 1998. The Southern Hemisphere midlatitudes exhibit near-zero or slightly positive trends over the whole stratosphere, for 1998-2018; we note that zero trends are included inside the corresponding error bars, although we did not add (grey) data error bars in these (already busy) plots. We note also that the upper-stratospheric early 


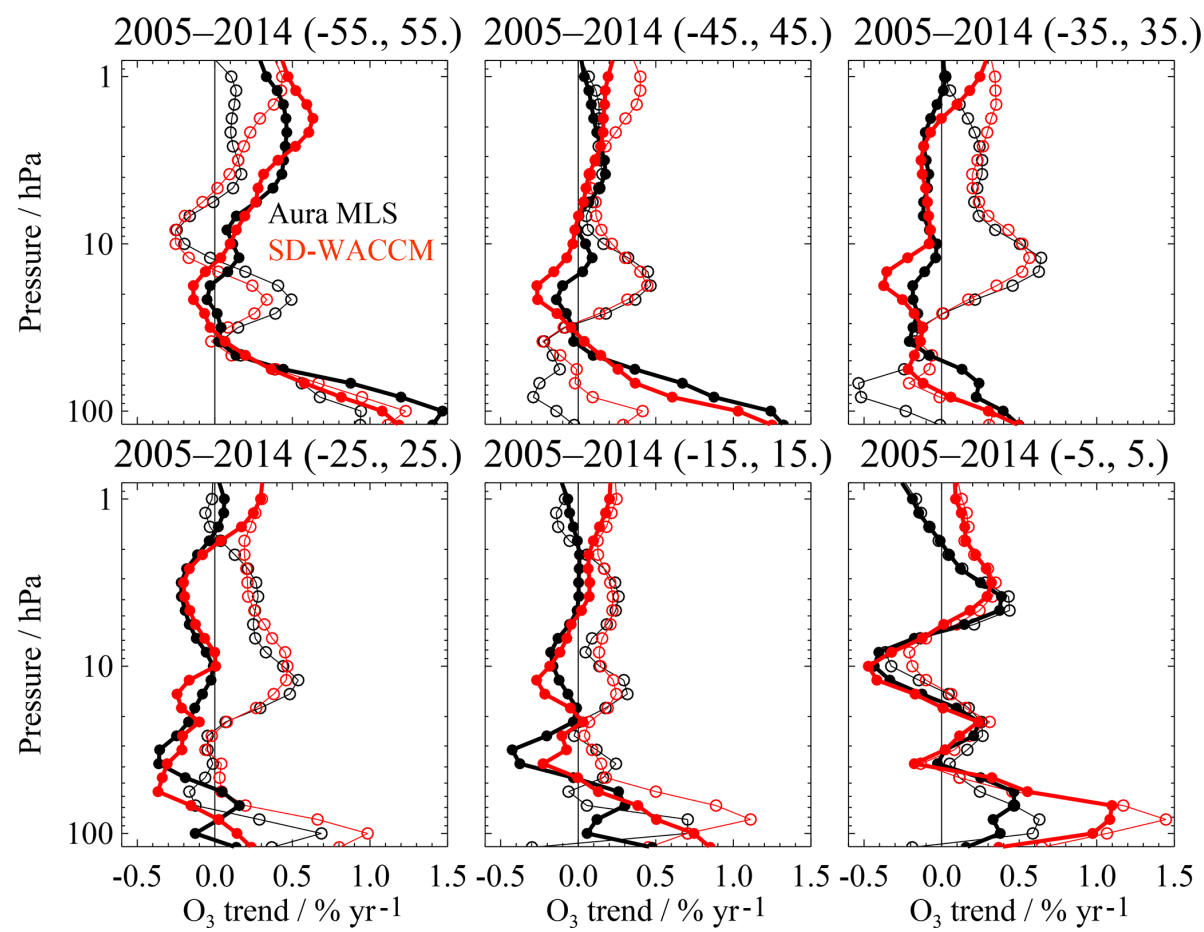

Figure 20. Ozone trends in different latitude bins for SD-WACCM (red) versus Aura MLS data (black) for 2005-2014. Closed and open circles are for northern and southern latitude bins, respectively. For clarity, error bars are omitted here, as these generally show that modeldata trend differences are not significant for this time period.

recovery (positive trends) is robust in the GOZCARDS data record, but the SD-WACCM trend results for the uppermost region tend to overestimate the observed trends and lie outside the error bars in a few cases. We show in Fig. $\mathrm{S} 15$ the $\mathrm{O}_{3}$ anomaly series for $1998-2014$ at $1 \mathrm{hPa}$ for $30-60^{\circ} \mathrm{N}$, where SD-WACCM and GOZCARDS trends lie outside their $2 \sigma$ error bars (Fig. 21); here, FR-WACCM happens to be in better agreement with the data. One aspect that could impact model-data differences is that the models are not sampled, here, following the sparser (occultation) viewing, neither in latitude nor in time (time within each month and local time also, since model values are $24 \mathrm{~h}$ averages). Also, some of the differences in the upper stratosphere might arise because the averaging of sunset and sunrise occultation data is not as robust for 1998-2004 as for pre-1998, when SAGE II was operating continuously in both modes (and $\mathrm{O}_{3}$ varies more strongly with local time at $1 \mathrm{hPa}$ than at lower altitudes). Also, HALOE had decreasing spatiotemporal coverage in later years. Denser spatial and temporal sampling is obtained for the MLS period, with very regular sampling; while small systematic (sampling-related) differences may affect the comparisons, such differences should be consistent from year to year, thus minimizing the impact on trend differences.

Our ozone trend results are largely consistent with other previous work (references mentioned above), which (for records including MLS) typically used merged $\mathrm{O}_{3}$ from
GOZCARDS or from SWOOSH (Davis et al., 2016). We find statistically significant trends (meaning that a zero trend is not included in the $2 \sigma$ error bar range) mostly in the upper stratosphere, both pre-1997 and after 1998. While the GOZCARDS results point to some small $\mathrm{O}_{3}$ decreases in the lower stratosphere post-1998, as obtained recently by the novel analyses of Ball et al. (2018), our study finds little statistical significance there and a fair level of sensitivity to the starting year or to the data sets used, with a swing to more positive (but marginally significant) results, if the starting year is 2005 (Fig. 19). Past work (e.g., Harris et al., 2015) has also shown sensitivity to start and end points; also, different regression analysis methods can lead to non-negligible differences (e.g., Nair et al., 2013; Kuttippurath et al., 2015). We also note that past analyses of lower-stratospheric tropical $\mathrm{O}_{3}$ data have shown positive tendencies, based not just on satellite data as indicated here (with marginal significance for now), but also based on SCIAMACHY data (Gebhardt et al., 2014); in that work, a positive trend was also seen in averaged tropical ozonesonde data. The lower-stratospheric ozone trend issue will continue to require further data and additional studies, towards a longer-term result.

For $\mathrm{H}_{2} \mathrm{O}$, there have been conflicting past results on stratospheric trends, depending on whether one investigates sonde or satellite data (e.g., Oltmans et al., 2000; Scherer et al., 2008), and regarding mechanisms that could account for more than a few tenths of a percent per year increase in $\mathrm{H}_{2} \mathrm{O}$, 

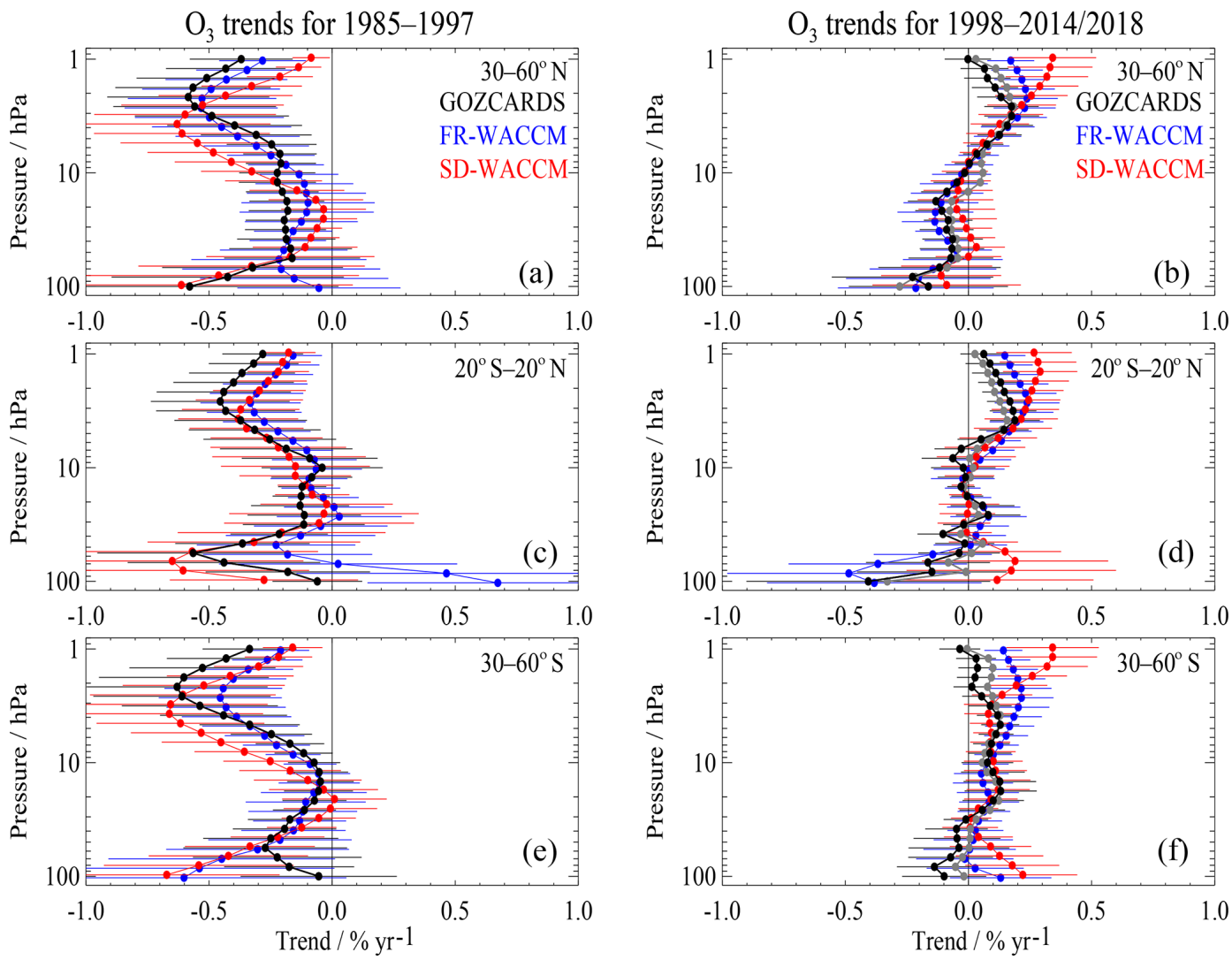

Figure 21. Same as Fig. 19 for ozone trend comparisons, except for the use of longer-term GOZCARDS (version 2.20) ozone data records, with 1985-1997 shown in (a, c, e) and 1998-2014 in (b, d, f), along with the corresponding model results. We also show the updated ozone data trends with 1998-2018 results in grey (for b, d, f).

as $\mathrm{CH}_{4}$ increases do not appear to be large enough for this. Changes in cold point temperatures or in the circulation need to be invoked in order to account for significant decadal-scale trends in $\mathrm{H}_{2} \mathrm{O}$ (e.g., Randel et al., 2000; Rohs et al., 2006; Tian and Chipperfield, 2006; Hegglin et al., 2014). Based on our analyses for 2005-2014, we find from Fig. 22 (a, c, and e) a positive $\mathrm{H}_{2} \mathrm{O}$ trend both in the MLS data and in SDWACCM, which tracks observations (versus latitude as well as pressure) better than FR-WACCM does. FR-WACCM exhibits systematically smaller $\mathrm{H}_{2} \mathrm{O}$ trend values than both MLS and SD-WACCM at all pressures except near $100 \mathrm{hPa}$. The fact that FR-WACCM trend results for the 2005-2014 period are significantly smaller for the mid-stratosphere to lower mesosphere than the SD-WACCM and observed trends appears to mainly be a result of slightly different decadal variability in this run; we also see instances in longer time series (not shown) where FR-WACCM short-term changes appear to be larger than those from SD-WACCM. Finally, the FR-WACCM trends have smaller error bars, given the lower variability found in this model over the time period investigated here. With such lower variability, detection of a given trend would take less time than with the actual (observed) variability. The overlap for FR-WACCM and MLS is marginal in the upper stratosphere and lower mesosphere, where the impact on $\mathrm{H}_{2} \mathrm{O}$ from $\mathrm{CH}_{4}$ decomposition should be at its maximum, and cold point temperature variability issues are smaller than near the tropical tropopause; also, the solar cycle effects on the $\mathrm{H}_{2} \mathrm{O}$ time series are largest in the upper mesosphere (see also Froidevaux et al., 2015), but our regression analysis includes a solar flux term (see Appendix A3) and largely takes this effect out. For the longer timescale provided on the right side of Fig. 22, for $\mathrm{H}_{2} \mathrm{O}$ trends since 1992, we see that the upper-stratospheric and mesospheric trends are much closer to zero than for 2005 2014 or 2005-2018. We have used 2010 as the end year for the model comparisons here to minimize the impact of drifts in the MLS $\mathrm{H}_{2} \mathrm{O}$ trend results (see the next paragraph for further details); trend results for 1992-2018 are provided as a reference but should be considered as an upper limit, given this drift issue for (roughly) the last 8 years of MLS data. An analysis of $\mathrm{H}_{2} \mathrm{O}$ HALOE profiles and ground-based microwave profiles over Hawaii (Nedoluha et al., 2009) showed that changes in upper-stratospheric and mesospheric $\mathrm{H}_{2} \mathrm{O}$ were indeed sensitive to the solar cycle but showed only negligible overall trends between 1992 and 2008. We can also see this evidence for smaller trends in the earlier por- 

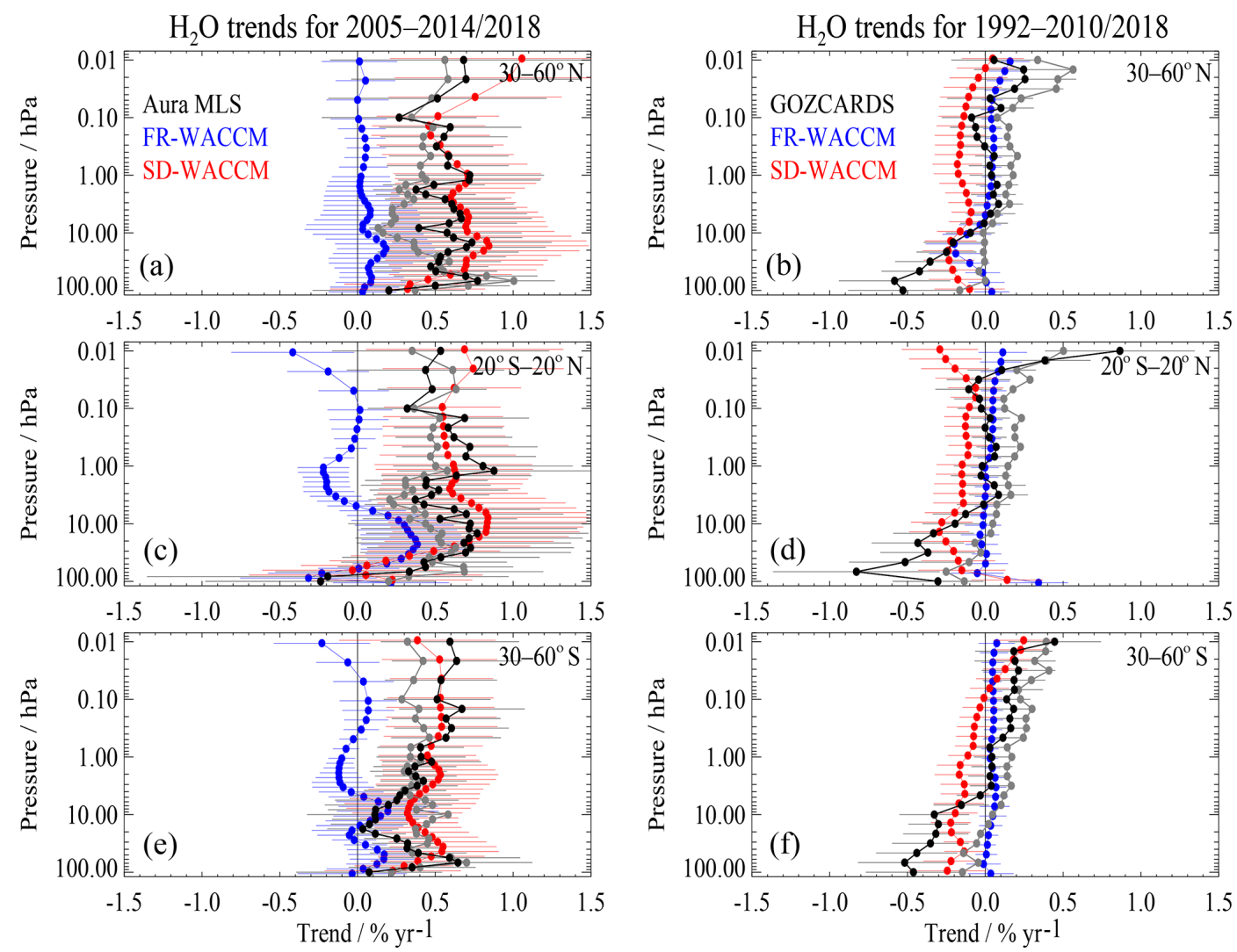

Figure 22. Trends in three latitude bins for stratospheric and mesospheric $\mathrm{H}_{2} \mathrm{O}$ from an analysis of the 2005-2014/2018 MLS data and the two WACCM models for 2005-2014/2018 (a, c, e) and the 1992-2010/2018 time period (b, d, f); only the observational trend results are extended through 2018 (grey points) for MLS (a, c, e) and for GOZCARDS (b, d, f).

tion of the $\mathrm{H}_{2} \mathrm{O}$ record in time series (not shown here) from the GOZCARDS data set, with the stronger part of the trend coming after 2007 (as confirmed by the Fig. 22 results). The causes for $\mathrm{CH}_{4}$ changes over the past few decades have been difficult to identify with confidence (see Feldman et al., 2018; Turner et al., 2017). Simple algebra indicates that such $\mathrm{CH}_{4}$ changes can lead to only part (about half) of the $\mathrm{H}_{2} \mathrm{O}$ increases reflected in the 2005-2014 trends, and there must be other reasons for these fairly large short-term trends. We believe that the significant decadal variability in $\mathrm{H}_{2} \mathrm{O}$, which arises from cold point temperature variability, propagated upward as a "tape recorder" signal, and QBO variability account for a large part of the large positive $\mathrm{H}_{2} \mathrm{O}$ trends for 2005-2014. Indeed, Garcia et al. (2007) noted in their studies of WACCM trends that multiple decades are likely needed to enable detection of the underlying secular rise in stratospheric $\mathrm{H}_{2} \mathrm{O}$, given the variability arising from ENSO, cold point temperature changes, the $\mathrm{QBO}$, and other factors. Also, a sudden drop in water vapor after 2000 can lead to a stronger post-2000 stratospheric $\mathrm{H}_{2} \mathrm{O}$ trend, if one is considering a rather short time period. In terms of the lower-stratospheric longer-term trend results, Fig. 22 (b, d, and f) shows that there have been some decreases since 1992 (and with the
1992-2018 results being viewed as an upper limit). Based on time series (not shown here), the models underestimate these decreases and show less variability, in terms of significant drops in water vapor as well as smaller positive oscillations; other factors that could contribute to these differences include the poorer atmospheric sampling prior to the MLS data and potential systematic uncertainties in the merged data set (which is a more difficult hypothesis to test).

We should also note that water vapor drifts have been detected between coincident MLS and sonde $\mathrm{H}_{2} \mathrm{O}$ data, mostly since about 2010, with MLS-derived trends being more positive than those from frost point profiles (Hurst et al., 2016). This relative drift (of as much as $0.5-1.6 \% \mathrm{yr}^{-1}$ for 2010 2015 , depending on altitude and location) could play a role in some discrepancies between model (SD-WACCM) and MLS trends for 2005-2014, and it does complicate such comparisons. While SD-WACCM results agree well with MLS in Fig. 22 (a, c, and e), they would become larger than MLS (adjusted) results if one were to subtract more than about $0.3 \% \mathrm{yr}^{-1}$ from these MLS trends, although we should keep the error bars in mind. Possible causes for drifts between MLS and sonde $\mathrm{H}_{2} \mathrm{O}$ data are being investigated, with only a small part of this discrepancy currently attributable to a 


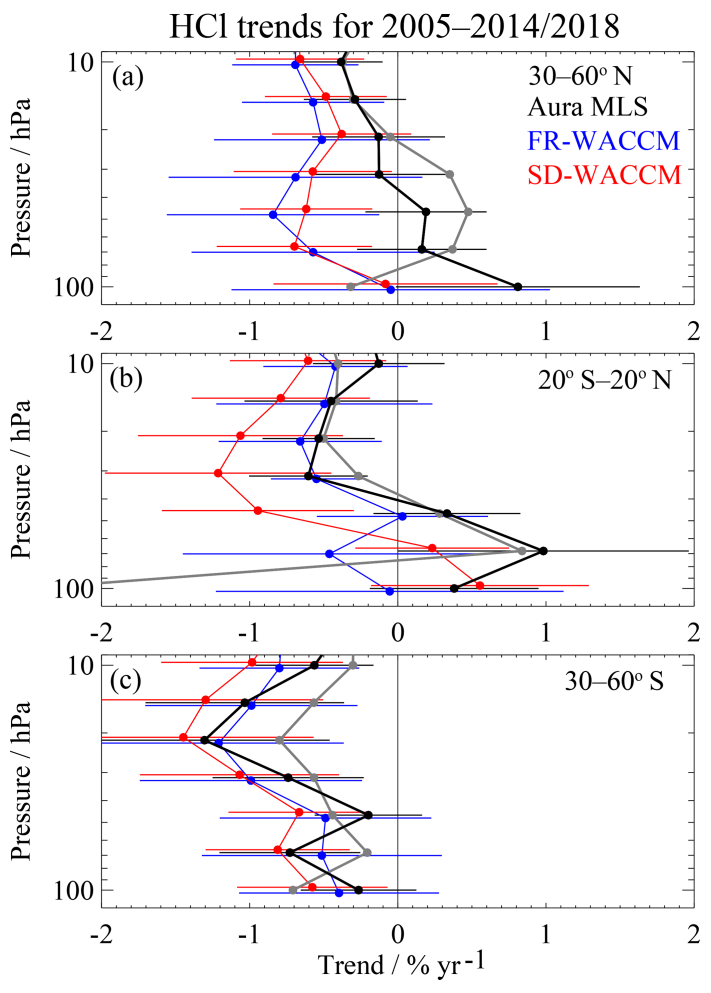

Figure 23. Same as Fig. 19 but for lower-stratospheric MLS $\mathrm{HCl}$ data trends for 2005-2014/2018 (with grey points showing MLS results through 2018) and WACCM HCl trends for 2005-2014.

known instrument degradation issue for $\mathrm{MLS} \mathrm{H}_{2} \mathrm{O}$, which probably impacts other MLS data from the $190 \mathrm{GHz}$ spectral region (notably $\mathrm{N}_{2} \mathrm{O}$ ). We see that tropical $\mathrm{H}_{2} \mathrm{O}$ at $100 \mathrm{hPa}$ (near the stratospheric water vapor entry level) does not display much of a trend. Previous studies of entry-level $\mathrm{H}_{2} \mathrm{O}$ using satellite data have concluded that no significant longterm trend is discernible (Hegglin et al., 2014; Dessler et al., 2014). The former study led to slightly negative lowerstratospheric $\mathrm{H}_{2} \mathrm{O}$ trends (although with no statistical significance). GOZCARDS $\mathrm{H}_{2} \mathrm{O}$ data used here, however, do not include SAGE II data back to the late 1980s, as was the case in the work by Hegglin et al. (2014), who also obtained positive long-term (1980-2010) trends in the upper stratosphere from satellite-derived $\mathrm{H}_{2} \mathrm{O}$ anomalies, merged using a global $\mathrm{CCM}$ as a transfer function. As found by others, especially when dealing with large decadal-type variability, the choice of start and end points, as well as the length of period studied, can significantly influence trend values, be it for $\mathrm{H}_{2} \mathrm{O}$ or $\mathrm{O}_{3}$. Lower-stratospheric $\mathrm{H}_{2} \mathrm{O}$ trend detection is rendered difficult by such variability, including significant short-term changes (Randel et al., 2006; Hurst et al., 2011; Fueglistaler, 2012; Urban et al., 2014), as noted here also (see Fig. S12).

For $\mathrm{HCl}$, changes in stratospheric values have been nonlinear, with a rapid rise prior to 1998 and a slower decrease after 2004, as expected from time-shifted abundances of total surface chlorine (Froidevaux et al., 2015). Focusing first on 2005-2014/2018, we show model and data $\mathrm{HCl}$ trends for the lower stratosphere in Fig. 23. The agreement between SD-WACCM and MLS trends (for 2005-2014) is good, especially for $30-60^{\circ} \mathrm{S}$, although the error bars are fairly large. However, the (negative) $\mathrm{HCl}$ trend results from both models lie below the observed trends almost everywhere. The upper portion of this model-data bias follows what we observe also in the upper stratosphere (not shown), where MLSderived $\mathrm{HCl}$ trends are too shallow compared to expectations (from model and surface-derived chlorine trends), whereas upper-stratospheric trends from the original MLS HCl product were more negative (see Froidevaux et al., 2006; Livesey at al., 2018). As a reminder, the MLS team recommends that data users not include upper-stratospheric MLS HCl data (post-2006) in any trend studies. For the lower stratosphere, where the $\mathrm{HCl}$ line is broader, there is less concern about the inability to track the $\mathrm{HCl}$ trend. Also, the near-zero drifts (drifts $<0.1 \% \mathrm{yr}^{-1}$ ) obtained between two separate $\mathrm{MLS} \mathrm{O}_{3}$ band retrievals (not shown), one from the same radiometer as $\mathrm{HCl}$ and one from the main (very stable) standard MLS $\mathrm{O}_{3}$ product (see Hubert et al., 2016), provide some confidence regarding the stability of $\mathrm{LS} \mathrm{HCl}$ trends. At low latitudes, MLS HCl shows a positive tendency (largest at $68 \mathrm{hPa}$, per Fig. 23), albeit with marginal significance. The vertical gradient in these trends is duplicated fairly well by the SD-WACCM results, although the model trends are usually less than those from MLS. Latitude-pressure trend variability, including positive tendencies, could be related to circulation changes, as implied by analyses of short-term increases in lower-stratospheric $\mathrm{HCl}$ seen in both ground-based and GOZCARDS data (Mahieu et al., 2014). For the most part, the MLS trend results for $\mathrm{HCl}$ do not change appreciably when we consider the longer period through 2018 (grey points in Fig. 23). Given the rapid rise in chlorine prior to 1998 and the nonlinear changes near the peak period, we show in Fig. 24 lower-stratospheric time series from GOZCARDS merged $\mathrm{HCl}$ (Froidevaux et al., 2015) and WACCM for 1992-2014. There is fairly good agreement in the nonlinear behavior observed in both data and model series. The scatter in $\mathrm{HCl}$ data decreases after 2005, and the earlier time series suffer from more inhomogeneous sampling, which may at least in part explain the larger scatter and modeldata differences (there is no attempt here to sample models within each month like the data, and this would be difficult for a merged data set). There are also regions and periods of slow $\mathrm{HCl}$ increases in both data and models (Fig. 24), as well as hemispheric differences in short-term tendencies (Mahieu et al., 2014; Froidevaux et al., 2015). The HCl time series are tracked well by SD-WACCM, which generally matches the data better than FR-WACCM; this is consistent with the understanding that dynamically driven variations are better captured by the incorporation in SD-WACCM of realistic meteorological fields (MERRA). Stolarski et al. (2018) investigated the removal of dynamical variability from MLS lower-stratospheric $\mathrm{HCl}$ series by using $\mathrm{MLS} \mathrm{N}_{2} \mathrm{O}$ data as a 

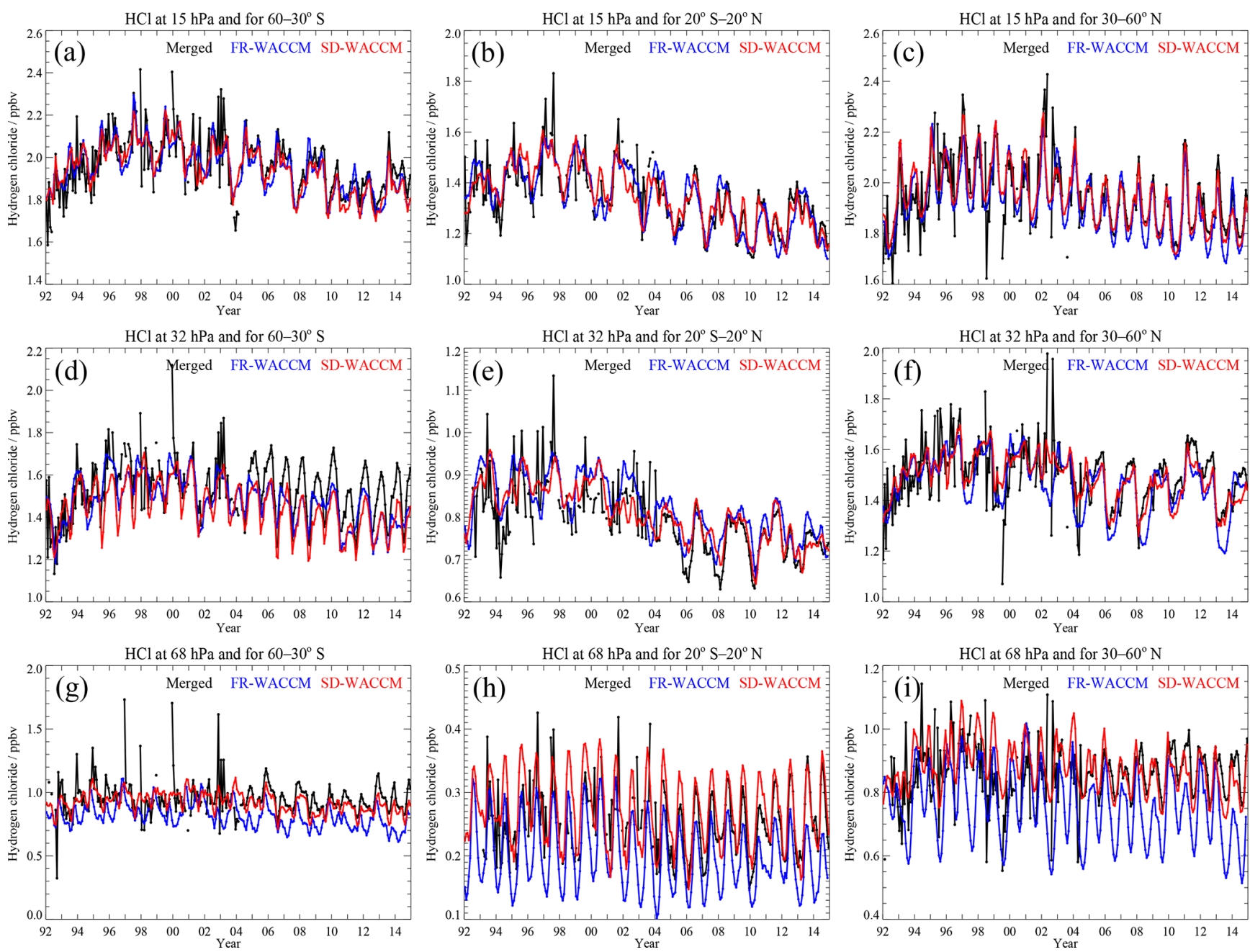

Figure 24. Time series (1992-2014) of lower-stratospheric HCl (ppbv) for the GOZCARDS HCl merged data record (black), as well as models (FR-WACCM in blue and SD-WACCM in red). Each panel is for a different pressure level and latitude bin, as labeled (15 hPa, a-c; $32 \mathrm{hPa}, \mathbf{d}-\mathbf{f} ; 68 \mathrm{hPa}, \mathbf{g}-\mathbf{i})$; the three latitude bins used in this work are $30-60^{\circ} \mathrm{S}(\mathbf{a}, \mathbf{d}, \mathbf{g}), 20^{\circ} \mathrm{S}-20^{\circ} \mathrm{N}(\mathbf{b}, \mathbf{e}, \mathbf{h})$, and $30-60^{\circ} \mathrm{N}(\mathbf{c}, \mathbf{f}, \mathbf{i})$.

fitting function in the regression; this led to $\mathrm{HCl}$ trends that match expectations based on changes in surface chlorine. The search for detailed explanations of such short-term increases and variability in lower-stratospheric $\mathrm{HCl}$ (and other composition changes) continues to be an interesting area of investigation.

In the upper stratosphere, it has been difficult to explain the details of observed $\mathrm{HCl}$ variations from 1998 to 2002, including the dip between these years (Waugh et al., 2001). We show in Fig. S16 near-global $\left(60^{\circ} \mathrm{S}-60^{\circ} \mathrm{N}\right)$ GOZCARDS $\mathrm{HCl}$ series at $1 \mathrm{hPa}$. This shows a systematic model underestimate of $\mathrm{HCl}$ in the uppermost stratosphere; the modeldata difference is much smaller at pressures closer to $5 \mathrm{hPa}$. While the systematic uncertainties (of $\sim 0.2 \mathrm{ppbv}$ ) in the data encompass the model values, the model total should be increased by the chlorine contribution from very short lived halogenated substances (VSLS) to the stratosphere; although this contribution is only of order $0.1 \mathrm{ppbv}$ (Carpenter et al.,
2014), recent evidence suggests that there could be a somewhat larger stratospheric chlorine contribution from VSLS (Oram et al., 2017). Nevertheless, the historical maximum for total tropospheric chlorine was about $3.65 \mathrm{ppbv}$ (WMO, 2014), and this should be the maximum total chlorine expected in the uppermost stratosphere. While WACCM includes the proper abundance and evolution of chlorine source gases, maximum WACCM $\mathrm{HCl}$ in the upper stratosphere (and lower mesosphere) is just under 3.4 ppbv. It is also interesting that the gap between the models (both versions) and the data worsens from 1992 to 2000, with the $\mathrm{HCl}$ peak occurring later in the data (with a broader peak than in the models). After about 2002, the decrease in near-global $\mathrm{HCl}$ roughly follows the model decrease; additional years of $\mathrm{HCl}$ data from ACE-FTS should help refine this comparison. In terms of $\mathrm{HCl}$ trends, Hossaini et al. (2019) have recently shown that there are positive changes (by $\sim 15 \%$ ) in model upper-stratospheric $\mathrm{HCl}$ trends since 2000 , i.e., the $\mathrm{HCl}$ de- 
creases are smaller, if one takes into account the likely impact of changes in stratospheric chlorine from VSLS.

For $\mathrm{N}_{2} \mathrm{O}$ and $\mathrm{HNO}_{3}$, lower-stratospheric model trends are compared to the corresponding MLS data trends in Fig. 25. We note that the MLS standard product right after launch was $\mathrm{N}_{2} \mathrm{O}-640$ (retrieved from the $640 \mathrm{GHz}$ radiometer data), but it was discontinued after mid-2013, as a result of a hardware degradation issue affecting that band $\left(\mathrm{N}_{2} \mathrm{O}\right.$ only). The current MLS product, $\mathrm{N}_{2} \mathrm{O}-190$, is retrieved from the $190 \mathrm{GHz}$ band. Figure S17 provides evidence of negative drifts in lowerstratospheric $\mathrm{N}_{2} \mathrm{O}-190$, apparently accelerating in the last few years, since the SD-WACCM and actual $\mathrm{N}_{2} \mathrm{O}$ values would be expected to continue to rise slowly after the end date on this plot, notably in the tropical lower stratosphere, where $\mathrm{N}_{2} \mathrm{O}$ should follow tropospheric trends. Indeed, tropospheric $\mathrm{N}_{2} \mathrm{O}$ has been increasing at a fairly steady rate of $\sim 0.26 \% \mathrm{yr}^{-1}$ (WMO, 2014), consistent with the model $\mathrm{N}_{2} \mathrm{O}$ and MLS $\mathrm{N}_{2} \mathrm{O}-640$ lower-stratospheric increases at low latitudes (see Fig. S17 and especially the tropical trends in Fig. 25 at $100 \mathrm{hPa}$ ). FR-WACCM $\mathrm{N}_{2} \mathrm{O}$ trends show slightly poorer agreement than SD-WACCM versus $\mathrm{N}_{2} \mathrm{O}-640$, although this is not statistically significant. Tropical lowerstratospheric MLS $\mathrm{N}_{2} \mathrm{O}-190$ trends (not shown) are negative (albeit with error bars that encompass small positive trends) but show some differences versus expectations and the $\mathrm{N}_{2} \mathrm{O}-640$ results. As for $\mathrm{HCl}$, interhemispheric differences in lower-stratospheric $\mathrm{N}_{2} \mathrm{O}$ trends are interesting in terms of their implications for effects relating to transport (age of air) and changes in the circulation. At lower pressure values, the $\mathrm{N}_{2} \mathrm{O}$ trends do not mirror the tropospheric $\mathrm{N}_{2} \mathrm{O}$ trends (in $\% \mathrm{yr}^{-1}$ ), and other factors play a role (changes in circulation, QBO, $\mathrm{N}_{2} \mathrm{O}$ photodissociation). The asymmetry in age of air obtained by analyses of (2002-2012) MIPAS $\mathrm{SF}_{6}$ data (Haenel et al., 2015) could also be related to asymmetries in $\mathrm{N}_{2} \mathrm{O}$ tendencies. They found relatively older air in the northern extra-tropics and younger air in the southern extra-tropics; this could also imply opposite trends for $\mathrm{N}_{2} \mathrm{O}$ between southern and northern lower stratosphere. However, Bönisch et al. (2011) have pointed out that tracers (e.g., $\mathrm{O}_{3}$ and $\mathrm{N}_{2} \mathrm{O}$ ) can be impacted differently by both vertical and quasi-horizontal transport effects, depending on their relative vertical and meridional gradients. Moreover, their work indicates that detailed attribution of tracer variations to structural changes in the Brewer-Dobson circulation is a complex matter, and short-term and longer-term changes may well have different characteristics. Our work mainly identifies similarities between some of the trend patterns versus pressure and latitude from SD-WACCM, in particular, and the observed trends, for a fairly short-term period. For the $\mathrm{HNO}_{3}$ trends (Fig. 25), we see fairly good agreement between models and data for 2005-2014; latitudinal tendencies and interhemispheric differences therein are similar for model and data. The spatial gradients of these species are different in the lower-stratosphere $\left(\mathrm{HCl}\right.$ and $\mathrm{HNO}_{3}$ increase with height, in contrast to $\mathrm{N}_{2} \mathrm{O}$ ), and we see that the decreas- ing $\mathrm{HCl}$ trends for $2005-2014$ at $30-60^{\circ} \mathrm{S}$ (Fig. 23), in particular, are qualitatively similar to those from $\mathrm{HNO}_{3}$ in this region. For lower-stratospheric $\mathrm{HNO}_{3}$, there is an underlying trend part caused by the slow increases in $\mathrm{N}_{2} \mathrm{O}$, as we can observe in longer-term (1980 to present) model time series (not shown here), but more abundant volcanic aerosols also led to large $\mathrm{HNO}_{3}$ changes, tied to heterogeneous chemistry, in the 1980-1992 time period. $\mathrm{N}_{2} \mathrm{O}$ and $\mathrm{H}_{2} \mathrm{O}$ (source gases for $\mathrm{HNO}_{3}$ ) are significantly affected by the QBO, and there is a strong related variability in lower-stratospheric $\mathrm{HNO}_{3}$. Observed short-term trend patterns in $\mathrm{HCl}, \mathrm{HNO}_{3}$, and $\mathrm{N}_{2} \mathrm{O}$ are better captured by SD-WACCM, overall, than by FRWACCM, as we show in Fig. S18 for the 2005-2010 period, which is relevant to the results of Mahieu et al. (2014), who emphasized short-term $\mathrm{HCl}$ increases during this time. We note the correlation in these short-term trend results for $\mathrm{HNO}_{3}$ and $\mathrm{HCl}$ but an anti-correlation for $\mathrm{N}_{2} \mathrm{O}$ versus $\mathrm{HCl}$ (and $\mathrm{HNO}_{3}$ ). Figure 25 also shows that the inter-hemispheric asymmetry in trends for lower-stratospheric $\mathrm{HNO}_{3}$ has persisted for the 2005-2018 period, although longer-term SDWACCM results (not shown) indicate that this is not modeled as a stable pattern over several decades. Such shortterm tendencies and correlations (or anti-correlations) were also noted by Douglass et al. (2017), who emphasized the results from various column time series, from both observational records and model simulations (including modeled age of air).

\section{Conclusions}

We have analyzed stratospheric data (and mesospheric data as well for $\mathrm{H}_{2} \mathrm{O}$ ) in terms of absolute abundances, variability, and trends for several species $\left(\mathrm{O}_{3}, \mathrm{H}_{2} \mathrm{O}, \mathrm{HCl}, \mathrm{N}_{2} \mathrm{O}\right.$, and $\mathrm{HNO}_{3}$ ), based on 10-14 years of Aura MLS measurements, as well as longer-term data records from GOZCARDS (for $\mathrm{O}_{3}, \mathrm{H}_{2} \mathrm{O}$, and $\mathrm{HCl}$ ). While our emphasis here has been on model evaluation and comparisons for two types of chemistry-climate model runs (the free-running and specified dynamics versions of CESM1 WACCM), we also point out certain observational highlights regarding stratospheric change, notably using recent MLS data through 2018. Our conclusions are thus largely separated in terms of (1) updates regarding atmospheric variations and trends, mostly for the $60^{\circ} \mathrm{S}-60^{\circ} \mathrm{N}$ region; and (2) model evaluation aspects, for comparisons through 2014 only.

Regarding the more novel highlights from satellite data analyses, we have used multiple linear regression to derive trends based on zonal mean time series from Aura MLS data alone, between $60^{\circ} \mathrm{S}$ and $60^{\circ} \mathrm{N}$. In the upper stratosphere, MLS $\mathrm{O}_{3}$ data show increases over 2005-2018 at a rate of $\sim 0.1-0.3 \% \mathrm{yr}^{-1}$ (depending on altitude and latitude) with $2 \sigma$ uncertainties of $\sim 0.2 \% \mathrm{yr}^{-1}$ (or less, for near-global averages). For the lower stratosphere (LS), GOZCARDS $\mathrm{O}_{3}$ data for 1998-2014 point to small decreases for broad lati- 

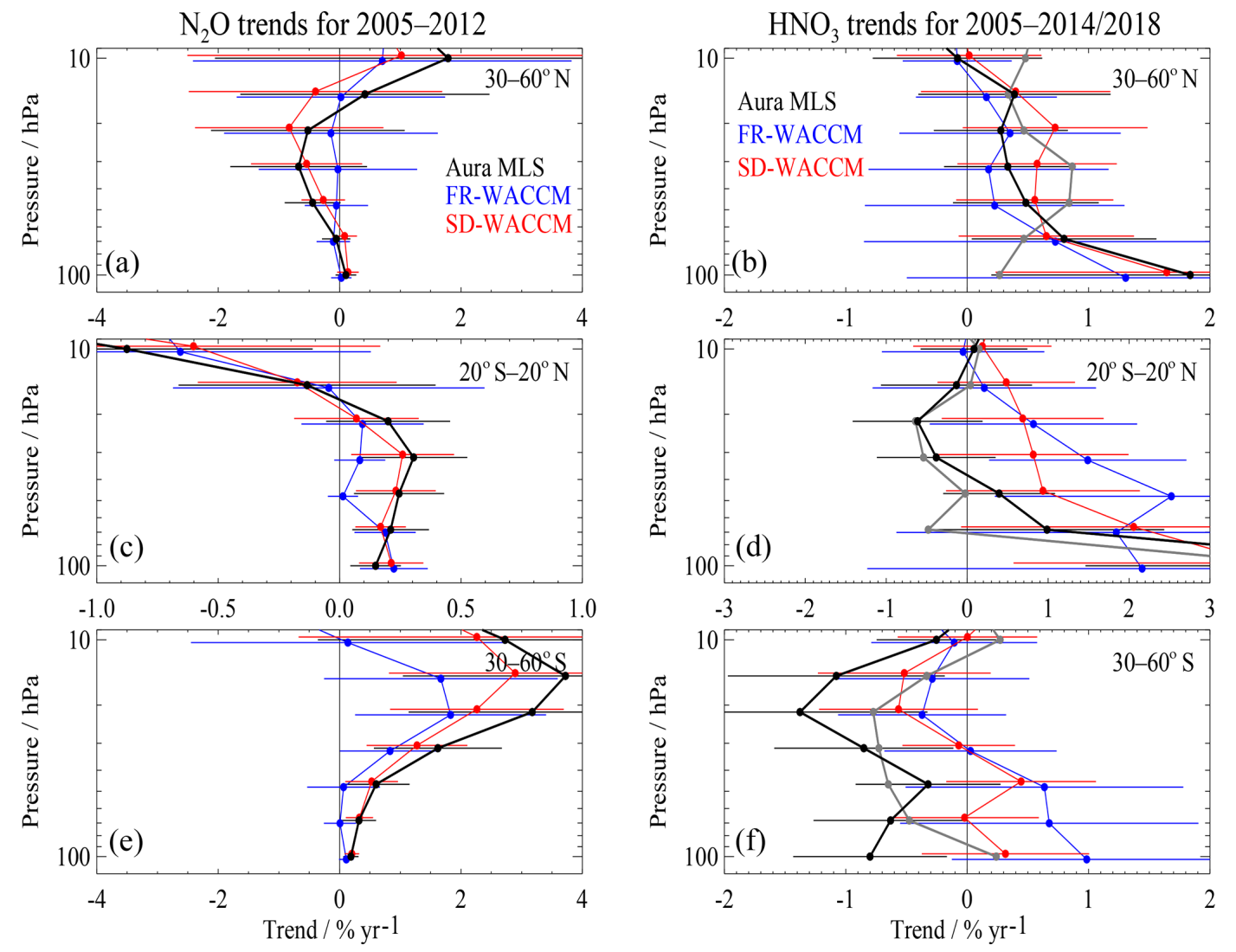

Figure 25. Same as Fig. 23 but for $\mathrm{N}_{2} \mathrm{O}(\mathbf{a}, \mathbf{c}, \mathbf{e})$ and $\mathrm{HNO}_{3}(\mathbf{b}, \mathbf{d}, \mathbf{f})$ data and model trends in the lower stratosphere. The $\mathrm{N}_{2} \mathrm{O}$ data results are from the $\mathrm{N}_{2} \mathrm{O}-640$ MLS product (retrieved from the $640 \mathrm{GHz}$ radiometer band data), which was discontinued in 2013 because of an instrument issue affecting this band (see text), and these data and model trends apply to the 2005-2012 period. The $\mathrm{HNO}_{3}$ trend results (data and models) are for 2005-2014, with additional data results (in grey) for 2005-2018.

tude regions between $60^{\circ} \mathrm{S}$ and $60^{\circ} \mathrm{N}$ (as obtained also by Ball et al., 2018), but we obtain more positive trends if the starting year is 2005 . The $\mathrm{SH}$ midlatitudes $\left(30-60^{\circ} \mathrm{S}\right)$ exhibit LS trends for 1998-2018 that are near zero (or slightly positive). The $\mathrm{LS} \mathrm{O}_{3}$ trends based on 2005-2018 MLS data are most positive at these SH midlatitudes (with trends of 0.1$0.2 \% \mathrm{yr}^{-1}$, although marginally statistically significant), in contrast to slightly negative or near-zero trends for 20052014. Also, at northern midlatitudes in the lower part of the stratosphere, a significant drop in $\mathrm{O}_{3}$ trends is obtained between the 2005-2014 results $\left(0.5-0.9 \% \mathrm{yr}^{-1}\right)$ and 20052018 (near-zero trends). Given the high variability in $\mathrm{LS} \mathrm{O}_{3}$, and the high sensitivity of trends to the choice of years used, especially for short time periods, further studies of this region are required for a more robust longer-term trend result. Only careful analyses of additional years of high-quality data can help to elucidate this question. For $\mathrm{H}_{2} \mathrm{O}$, upper-stratospheric and mesospheric trends based on GOZCARDS 1992-2010 data are near zero (within $\sim 0.2 \% \mathrm{yr}^{-1}$ ) and significantly smaller than trends (within $\sim 0.4-0.7 \% \mathrm{yr}^{-1}$ ) from MLS for 2005-2014 or 2005-2018. As shown before by others, there are multiple factors that can influence low-frequency vari- ability in $\mathrm{H}_{2} \mathrm{O}$; these recent stratospheric short-term positive trends go beyond what one would expect from changes associated with a slow, secular increase in methane, even if some of the recent $\mathrm{CH}_{4}$ changes have been nonlinear (Schaefer et al., 2016; Nisbet et al., 2016). However, given the known drift in MLS $\mathrm{H}_{2} \mathrm{O}$ series (mainly since 2010) versus in situ sonde data (Hurst et al., 2016), the MLS trends above should be viewed as upper limits. We also note that the very shallow solar flux maximum (in 2011 to 2014) of solar cycle 24 , with lower-than-usual flux, led to a more extended period of large mesospheric $\mathrm{H}_{2} \mathrm{O}$ since the minimum values observed in GOZCARDS time series in 2002 (see Froidevaux et al., 2015); this has contributed to the fairly large short-term mesospheric and upper-stratospheric $\mathrm{H}_{2} \mathrm{O}$ trends since 2005. For $\mathrm{HCl}$, the MLS data show regions and periods of small $\mathrm{HCl}$ increases in the lower stratosphere, within the context of the longer-term stratospheric decrease in $\mathrm{HCl}$, as well as interhemispheric-latitudinal differences in shortterm $\mathrm{HCl}$ tendencies. We observe similarities in such shortterm tendencies, and interhemispheric asymmetries therein, for lower-stratospheric $\mathrm{HCl}$ and $\mathrm{HNO}_{3}$, while $\mathrm{N}_{2} \mathrm{O}$ trend profiles exhibit anti-correlated patterns. Some studies have im- 
plied that such short-term trends relate to changes in age of air and circulation, and this is the subject of continuing analyses. More generally, we are reminded through such work that, especially when dealing with large decadal-type variability, the choice of start and end points, as well as the length of period studied, can significantly influence the resulting trend values, and certainly the shorter-term tendencies.

In terms of the model evaluation analyses, climatological averages for 2005-2014 from FR-WACCM and SDWACCM for $\mathrm{O}_{3}, \mathrm{H}_{2} \mathrm{O}, \mathrm{HCl}, \mathrm{N}_{2} \mathrm{O}$, and $\mathrm{HNO}_{3}$ compare generally favorably (within $2 \sigma$ systematic errors) with Aura MLS data averages over this period. Model $\mathrm{O}_{3}$ values are usually within $\pm 5 \%-10 \%$ of the data, except in the UTLS. In the lowest stratosphere, SD-WACCM generally exceeds the observed ozone means by $30 \%-50 \%$, with FR-WACCM showing a smaller overestimate; both models also overestimate (by $\sim 60 \%$ ) the amplitude of the annual cycle in this region. Such differences require further investigations but would appear to implicate, in part, a transport-related issue in the models. For $\mathrm{H}_{2} \mathrm{O}$, there is a model low bias (by $5 \%-$ $15 \%)$ versus MLS data in the upper stratosphere and most of the mesosphere, although some of this might be a result of a small high bias in MLS $\mathrm{H}_{2} \mathrm{O}$ versus other satellite data (Hegglin et al., 2013). Also, the models significantly underestimate average $\mathrm{HNO}_{3}$ values in the upper stratosphere, notably at high latitudes; this stems from the known effects of missing model ion chemistry, as it relates to particle precipitation effects in the mesosphere, followed by downward wintertime polar transport of enhanced $\mathrm{NO}_{x}$, and subsequent increases in $\mathrm{HNO}_{3}$. In the lower stratosphere at high southern latitudes, variations in polar winter and spring composition observed by MLS are generally well matched by SDWACCM, with the main exception being for the early winter rate of decrease in $\mathrm{HCl}$, which is too slow in the model (see also the work on this topic by Grooß et al., 2018). Regarding the fitted variability tied to the $\mathrm{AO}$ and SAO, there are a few discrepancies between model-derived amplitude patterns and the corresponding MLS climatology features, but FR-WACCM and SD-WACCM appear to properly capture the primary processes governing these modes of variability. We have provided diagnostics for the fits between WACCM runs and MLS deseasonalized anomaly series. These include correlation coefficients for different time series as well as a diagnostic of rms differences (model versus data) divided by the rms data variability. Not too surprisingly, SD-WACCM, which is driven by realistic dynamics, generally matches the observed zonal monthly mean anomalies significantly better than does FR-WACCM; this holds for all five species that we considered, with larger values of $R^{2}$ and smaller values of the rms difference diagnostic for SD-WACCM.

For a more fair and useful metric of model quality, in particular for a free-running model, we have compared the rms interannual variability from the anomalies in both WACCM models versus observations. One of the main features is that the $\mathrm{H}_{2} \mathrm{O}$ variability from the lower stratosphere to upper mesosphere is underestimated by both models; this underestimate can reach a factor of 2, although more typically it is of order $30 \%$. This implies that more years (by a factor of 1.2 to 1.6) would be needed to detect an actual trend in $\mathrm{H}_{2} \mathrm{O}$ than if one used the WACCM-based predictions. Ozone variability is better represented by WACCM, with model/data variability ratios typically within a factor of 0.8 to 1.2. Observed $\mathrm{HCl}$ variability is underestimated somewhat by FR-WACCM for 1992-2003 but not for 2005-2014; the sparser HALOE sampling, compared to MLS, could explain some of the underestimate for the early period, especially in polar regions. For $\mathrm{N}_{2} \mathrm{O}$, there is also a model underestimate (from both WACCM versions) of MLS-derived LS low-latitude variability, although this variability is small.

Regarding trends, the model comparisons versus the $\mathrm{O}_{3}$ data records from GOZCARDS (version 2.20) show generally good qualitative agreement in the time series for both upper- and lower-stratospheric change; the WACCM $\mathrm{O}_{3}$ trends estimated using the same regression model as used for the MLS data show good agreement with the data trends. Furthermore, the observed trend dependence on latitude and pressure is matched quite well by the SD-WACCM trend results. We have not considered the high latitudes in detail here, in part because of the significant dynamical variability in that region. Stone et al. (2018) recently analyzed model results at high latitudes in the upper stratosphere and showed that the large variability in that region, including the effects of solar proton events, is likely to mask detection of recovery (for now). In the lower stratosphere, where larger variability exists, the $\mathrm{O}_{3}$ trends we deduce from the data and models agree within fairly large error bars (and generally with no statistical significance). For 2005-2014, the SD-WACCM trends seem to track the observed positive $\mathrm{O}_{3}$ tendencies, although with marginal statistical significance. For $\mathrm{H}_{2} \mathrm{O}$, the MLS and SD-WACCM positive trend results agree fairly well, but FR-WACCM shows significantly smaller increases; this discrepancy for FR-WACCM is even more pronounced for the longer-term GOZCARDS $\mathrm{H}_{2} \mathrm{O}$ records (since 1992). Larger discrepancies for FR-WACCM likely arise from its poorer correlations (than SD-WACCM) with cold point temperatures and with $\mathrm{QBO}$ variability. For $\mathrm{HCl}$, our trend analyses reveal broad agreement between the lower-stratospheric MLS data (2005-2014) and the models, but with some systematic differences. While decreases in global LS $\mathrm{HCl}$ are indicated for 2005-2014, there are some observed hemispheric differences, and some increase is suggested in tropical MLS data at $68 \mathrm{hPa}$, where there is only a slight positive trend from SD-WACCM. While the vertical gradients of MLS HCl trends are duplicated to some extent by SD-WACCM, the model trends are always more negative. We see a continued need for more comparisons of the various $\mathrm{HCl}$ measurements, satellite-based and ground-based, as well as for model comparisons, in order to better understand circulation influences on stratospheric composition, as well as potential measurement-related issues. Part of the model-data 
systematic difference in $\mathrm{HCl}$ trends could be explained by the omission (in WACCM) of the impact of VSLS on stratospheric chlorine, as indicated by the recent work of Hossaini et al. (2019). For $\mathrm{N}_{2} \mathrm{O}$, the interhemispheric asymmetry in MLS-derived trends (for 2005-2012), with negative trends (of up to $-1 \% \mathrm{yr}^{-1}$ ) at $\mathrm{NH}$ midlatitudes and positive trends (of up to $3 \% \mathrm{yr}^{-1}$ ) at $\mathrm{SH}$ midlatitudes, is in agreement with the asymmetry in SD-WACCM results. Small observed positive trends of $\sim 0.2 \% \mathrm{yr}^{-1}$ in the 100 to $30 \mathrm{hPa}$ tropical region are consistent with model results, which in turn are very close to the known rate of increase in tropospheric $\mathrm{N}_{2} \mathrm{O}$ (at about $+0.26 \% \mathrm{yr}^{-1}$; see WMO, 2014). In the case of $\mathrm{HNO}_{3}$, the MLS-derived lower-stratospheric trend differences (for 2005-2014) between hemispheres are opposite in sign to those from $\mathrm{N}_{2} \mathrm{O}$ (whose spatial gradients are largely of a sign opposite to those from $\mathrm{HNO}_{3}$ ) and in reasonable agreement with both WACCM results, despite large error bars. While more detailed analyses would be needed to try to relate such trend asymmetries to changes in age of air, or circulation, we note that the QBO is a large contributor to such short-term trend results in the middle stratosphere.

The diagnostics provided in this WACCM model evaluation can help distinguish even fairly subtle differences between models and observations, as well as between models. Further collaborations between modeling groups and instrument teams, as well as continuing data validation, will help to expose and clarify species-dependent instrumental effects (biases or drifts). Finally, independent CCMs are not created in the same way, and nudging approaches can vary; in addition, some models have an internally generated QBO, but most do not. While this study focused on CESM1 WACCM, continuing studies of the differences between high-quality observations and various models of atmospheric composition will be useful. Such work could be expanded to include species not considered here and/or with more of a focus on the upper troposphere.

Data availability. Aura MLS data used in this work are monthly zonal means derived from Level 2 MLS data, which are accessible from the Goddard Earth Sciences Data and Information Services Center (GES DISC), funded by NASA's Science Mission Directorate; a link for MLS Level 2 data access can be found at https: //mls.jpl.nasa.gov/data/ (last access: 4 April 2019). GOZCARDS data sets can be obtained (by entering GOZCARDS in the search) at http://disc.gsfc.nasa.gov (e.g. Anderson et al., 2013; Froidevaux et al., 2013; Wang et al., 2013). More recent years (and version updates) will be made available at this site or can be obtained by request to the first author. The WACCM model output used here is provided in some of the references and is available from the NCAR Earth System Grid at https://www.earthsystemgrid.org/search.html? Project=CCMI1 (last access: 4 April 2019). For WACCM, we thank NASA Goddard Space Flight Center for the MERRA data (accessed freely online at http://disc.sci.gsfc.nasa.gov/, last access: 4 April 2019). 

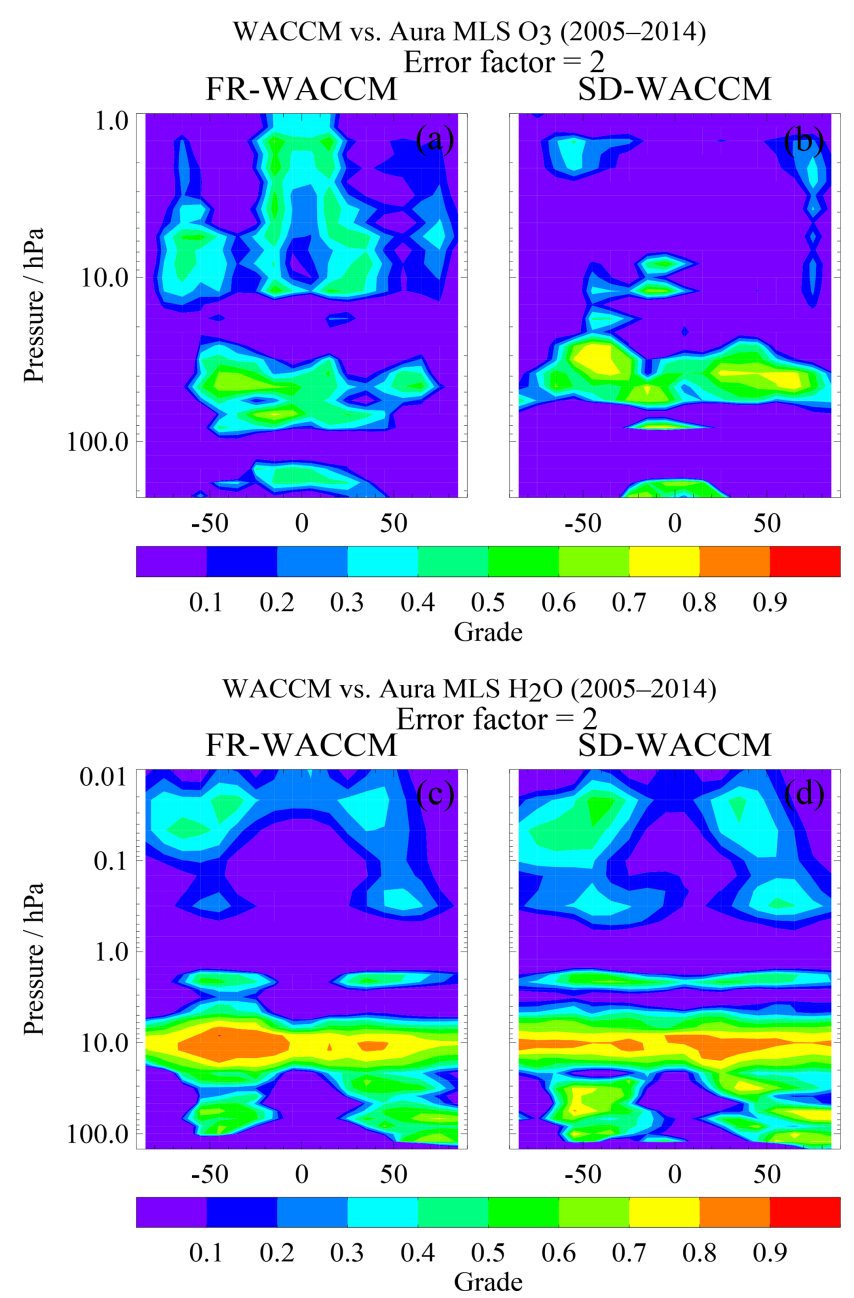

Figure A1. Examples of grades for model evaluations of $\mathrm{O}_{3}(\mathbf{a}, \mathbf{b})$ and $\mathrm{H}_{2} \mathrm{O}(\mathbf{c}, \mathbf{d})$, using a grading methodology that has been used in the past (see Eq. A1), applied to both FR-WACCM (a, c) and SDWACCM (b, d) time series versus Aura MLS time series from 2005 through 2014. These grades are for an error factor of 2 (in Eq. A1).

\section{Appendix A}

\section{A1 Examples of other model evaluation methods}

A grading method that has been applied in some previous comparisons (for example see Douglass et al., 1999; Waugh and Eyring, 2008) between atmospheric model values $\left(M_{n}\right)$ and observed values $\left(O_{n}\right)$ utilizes Eq. (A1) below to arrive at grades between 0 and 1 (and if a grade is $<0$, it can be set to $0)$ :

grade $=1-\sum_{1}^{N} \frac{\left|M_{n}-O_{n}\right|}{E_{\mathrm{f}} \times \sigma_{n}}$,

with index $n$ (in a given time series) varying between 1 and $N$ (the total number of monthly values being compared for a given latitude-pressure bin) and $\sigma_{n}$ representing the error in
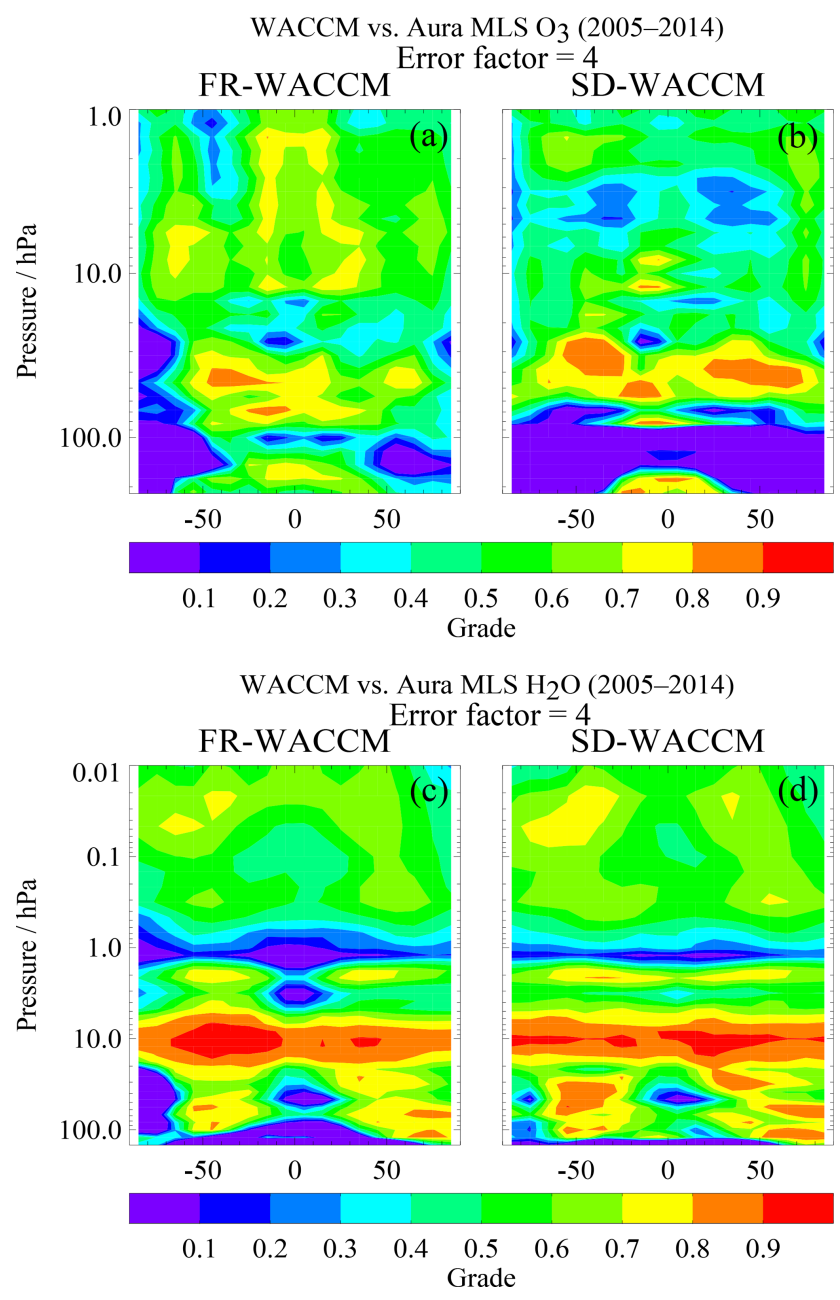

Figure A2. As in Fig. A1, for model evaluation grades of $\mathrm{O}_{3}$ and $\mathrm{H}_{2} \mathrm{O}$ (WACCM versus Aura MLS data), but for a value of 4 (rather than 2) for the error factor (see Eq. A1).

the observations. While the error factor $E_{\mathrm{f}}$ should probably be set to 2 or 3 , this gives grades that are too small (close to zero or negative) if one applies such a formula to the MLS $\mathrm{O}_{3}$ or $\mathrm{H}_{2} \mathrm{O}$ time series, specifically to data sets with pretty well defined total measurement errors (provided as $2 \sigma$ error estimates, per Sect. 4, meaning an error factor of 2). The grades shown here in Figs. A1 and A2 correspond to error factors $\left(E_{\mathrm{f}}\right)$ of 2 and 4, respectively. Figure $\mathrm{A} 2$ leads to $\mathrm{O}_{3}$ and $\mathrm{H}_{2} \mathrm{O}$ grades that are more useful than Fig. A1. It also shows some similarities with the diagnostics based on percent differences between model and data shown in Sect. 4.

We note, however, that it is generally more difficult to estimate systematic errors for merged data records. The GOZCARDS data analyses led to somewhat pessimistic (or conservative) systematic error estimates (see Froidevaux et al., 2015), and these are significantly larger than error estimates for MLS data only. Other methods could lead to useful error estimates, through the use of multi-satellite data sets and the 


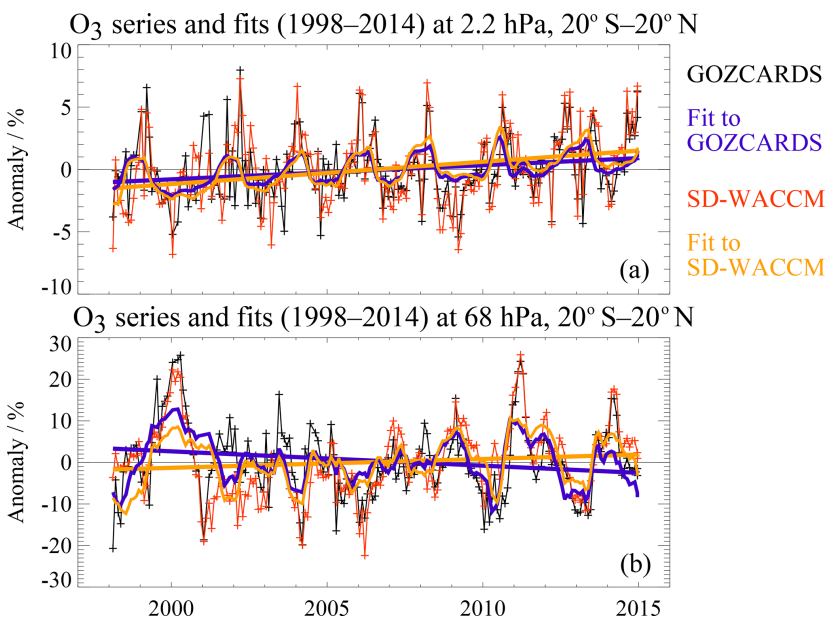

Figure A3. Deseasonalized monthly mean anomaly time series for $\mathrm{O}_{3}(\%)$ at $2.2 \mathrm{hPa}$ (a) and $68 \mathrm{hPa}$ (b), for 1998 through 2014, for averages over $20^{\circ} \mathrm{S}-20^{\circ} \mathrm{N}$. Note that the $y$ axis range for $68 \mathrm{hPa}(\mathbf{b})$ is 3 times larger than for $2.2 \mathrm{hPa}$ (a). The data set (black) is from the GOZCARDS ozone record, with the SD-WACCM (simulated) series (red) also shown. Fits to the observational series are in purple, and fits to the model series are in orange; the fitted time series functions (curves) and the fitted linear components (straight lines) are shown.

spread between these (see SPARC, 2017), for some species at least. Moreover, when one considers anomaly time series, it becomes even less clear how to best assign uncertainties in the context of error-weighted grades. Some data records may also drift with respect to others, or with respect to groundbased data, so that the actual errors will change with time (and possibly location). In the end, the most important aspect of model evaluation or grading analyses may lie in the relative values of grades or diagnostics for different models.

\section{A2 The rms difference diagnostic}

Given a model time series $M_{i}(t)$ and an observational time series (both series here representing deseasonalized anomalies) $O_{i}(t)$, the difference values between the two anomaly series are simply given by

$\Delta_{i}(t)=M_{i}(t)-O_{i}(t)$,

and the root mean square (rms) of these anomaly differences $\left(\mathrm{rms}_{\mathrm{dif}}\right)$ is expressed as

$\mathrm{rms}_{\mathrm{dif}}=\sqrt{\frac{1}{N} \sum_{i} \Delta_{i}^{2}}$.

The rms value (variability) of the observational series (of anomalies) in this case is

$\mathrm{rms}_{\mathrm{O}}=\sqrt{\frac{1}{N} \sum_{i} O_{i}^{2}}$
One of the diagnostics that we use in Sect. 4 to compare how well different models match up with the observed time series is given by the ratio of the above variability values:

$D_{\mathrm{rms}_{\mathrm{dif}}}=\frac{\mathrm{rms}_{\mathrm{dif}}}{\mathrm{rms}_{\mathrm{O}}}$.

\section{A3 Regression model}

\section{A3.1 Functional form}

The MLR model and fitting methodology used here are similar to the methods used by many others in the past, with a linear model description that uses annual, semiannual, QBO, and ENSO terms. Thus, the model function to be fitted for coefficients $a, b, c_{n}, d_{n}, f_{1}, f_{2}, f_{3}$, and $f_{4}$ has the familiar form:

$$
\begin{aligned}
& y(t)= \\
& a+b\left(t-t_{\mathrm{m}}\right)+\sum_{n}\left(c_{n} \sin 2 \pi t / P_{n}+d_{n} \cos 2 \pi t / P_{n}\right) \\
& +f_{1} \mathrm{QBO}_{1}(t)+f_{2} \mathrm{QBO}_{2}(t)+f_{3} \operatorname{ENSO}(t)+f_{4} \operatorname{Solar}(t),
\end{aligned}
$$

with the (monthly series) time variable expressed by $t$ and $t_{\mathrm{m}}$ chosen as the series midpoint; the linear trend term is coefficient $b$ above. The sine and cosine functions provide for periodic variations with periods $P_{n}$. For our work, we use the primary shorter-term periodic oscillations, namely the annual (12-month period) and semiannual (6-month period), in Eq. (A6), in addition to shorter-term periodic terms (with 3- and 4-month periods); such short-term variability helps to produce better fits and can reduce error bars slightly, although the resulting linear trend results are not affected much. The QBO is also a major source of variability in stratospheric composition time series. As a QBO proxy, we include the variability in monthly mean tropical wind series; we use the linear combination of (roughly orthogonal) equatorial wind series at 50 and $30 \mathrm{hPa}$ as the $\mathrm{QBO}_{1}$ and $\mathrm{QBO}_{2}$ functions above to account for phase shifts in the series at different locations. Monthly mean zonal equatorial wind data are made available by the Freie Universität Berlin (see http:// www.geo.fu-berlin.de/en/met/ag/strat/produkte/qbo/, last access: 10 January 2019, for data access information and references). We have also tested fits with the zonal mean wind vertical shear (gradient) rather than the wind itself as a proxy, but this did not make significant changes in the trends (or improvements in the residuals). The ENSO proxy follows the monthly mean Multivariate ENSO Index (MEI), which combines data from six main geophysical variables over the tropical Pacific (see Wolter and Timlin, 1993, 1998; https://www.esrl.noaa.gov/psd/enso/mei/index.html, last access: 10 January 2019). Also, we have included an 11-year solar cycle proxy term (see the last term in the above equation), using the monthly averaged $10.7 \mathrm{~cm}$ solar flux time series kindly provided (see ftp://ftp.geolab.nrcan.gc.ca/data/ solar_flux/monthly_averages, last access: 10 January 2019) 
by the Canadian Space Weather Forecast Centre. For further discussions of alternate fitting methods (e.g., methods using effective equivalent chlorine time series as a proxy), the reader is referred to the abundant literature on trend assessments (see WMO, 2014, and references therein). Our main goal here is to retrieve trends and trend errors from the data and the models in the same way. An example of deseasonalized tropical ozone time series at two pressure levels is given in Fig. A3, which shows MLS and SD-WACCM series, along with the fits and the linear trends.

\section{A3.2 Trend errors}

For the evaluation of error bars in the linear trends, we have used the method of bootstrap resampling (Efron and Tibshirani, 1986). As others have done for ozone trend analyses (Randel and Thompson, 2011; Bourassa et al., 2014), we have applied this using block bootstrapping (using yearly blocks of data), thereby preserving some of the dependency in the time series. Basically, one samples and (randomly) replaces blocks of yearly data for a large number of resampling cases (on linear fits to the residuals) and then calculates the standard deviation of this large number of trend results to arrive at trend uncertainties; note that we use $2 \sigma$ values as error bars in our comparisons (which is very close to $95 \%$ bounds). We have used 20000 samples in our bootstrap analyses; changing this number (e.g., by several thousand) does not alter the results significantly, as long as one chooses a large enough total number of cases. An alternative method is to attempt to correct trend uncertainties for the autocorrelation of the residuals after the regression fit (Tiao et al., 1990; Weatherhead et al., 1998; Santer et al., 2000). The existence of nonrandom residuals effectively implies that the number of independent data points is less than the number making up the original time series. The end result is that trend uncertainties are larger than if one neglects these effects. We find that trend errors from this bootstrap method for our time series examples are often larger than more simplistic/standard calculations by factors ranging from about 1.2 to 2 or more. We have checked our trend error calculations with the OSIRIS team (Christopher Roth, personal communication, 2018) based on a sample time series, as we have used the same block bootstrap approach as they have (see also Bourassa et al., 2014). 
Supplement. The supplement related to this article is available online at: https://doi.org/10.5194/acp-19-4783-2019-supplement.

Author contributions. LF produced the majority of this paper, including the figures. DK provided the model runs used in these comparisons to observational data from Aura MLS and GOZCARDS; he also described the models used here and provided substantial guidance and comments for this paper. HJW and JA, along with LF, were key participants in the development and creation of the GOZCARDS data sets, including the recently updated version (2.20) for merged ozone used herein. RF was another key participant in the GOZCARDS data production, and he also provided programming support for these model intercomparisons.

Competing interests. The authors declare that they have no conflict of interest.

Special issue statement. This article is part of the special issue "Chemistry-Climate Modelling Initiative (CCMI) (ACP/AMT/ESSD/GMD inter-journal SI)". It is not associated with a conference.

Acknowledgements. Work at the Jet Propulsion Laboratory, California Institute of Technology, was performed under contract with the National Aeronautics and Space Administration (NASA). GOZCARDS data were initially produced under the NASA Making Earth System Data Records for Use in Research Environments (MEaSUREs) program, with data continuity/updates now provided under MLS funding. We acknowledge insights and comments regarding aspects of this work from Rolando Garcia, Nathaniel Livesey, Jessica Neu, and Michelle Santee. We also appreciate discussions and comparison work regarding trends and error bars with Doug Degenstein and Chris Roth, as well as Emmanuel Mahieu (and via some of his European contacts). The National Center for Atmospheric Research (NCAR) is sponsored by the U.S. National Science Foundation (NSF). WACCM is a component of NCAR's Community Earth System Model (CESM), which is supported by the NSF and the Office of Science of the U.S. Department of Energy. Computing resources for WACCM were provided by NCAR's Climate Simulation Laboratory, sponsored by NSF and other agencies; we also acknowledge the computational and storage resources of NCAR's Computational and Information Systems Laboratory (CISL).

Review statement. This paper was edited by Gunnar Myhre and reviewed by three anonymous referees.

\section{References}

Anderson, J., Froidevaux, L., Fuller, R. A., Bernath, P. F., Livesey, N. J., Pumphrey, H. C., Read, W. G., Russell III, J. M., and Walker, K. A.: GOZCARDS Merged Water Vapor
1 month L3 10 degree Zonal Means on a Vertical Pressure Grid V1.01, Greenbelt, MD, USA, Goddard Earth Sciences Data and Information Services Center (GES DISC), https://doi.org/10.5067/MEASURES/GOZCARDS/DATA3004, 2013.

Andersson, M. E., Verronen, P. T., Marsh, D. R., Pälvärinta, S.-M., and Plane, J. M. C.: WACCM-D-Improved modeling of nitric acid and active chlorine during energetic particle precipitation, J. Geophys. Res.-Atmos., 121, 10328-10341, https://doi.org/10.1002/2015JD024173, 2016.

Ball, W. T., Alsing, J., Mortlock, D. J., Rozanov, E. V., Tummon, F., and Haigh, J. D.: Reconciling differences in stratospheric ozone composites, Atmos. Chem. Phys., 17, 1226912302, https://doi.org/10.5194/acp-17-12269-2017, 2017.

Ball, W. T., Alsing, J., Mortlock, D. J., Staehelin, J., Haigh, J. D., Peter, T., Tummon, F., Stübi, R., Stenke, A., Anderson, J., Bourassa, A., Davis, S. M., Degenstein, D., Frith, S., Froidevaux, L., Roth, C., Sofieva, V., Wang, R., Wild, J., Yu, P., Ziemke, J. R., and Rozanov, E. V.: Evidence for a continuous decline in lower stratospheric ozone offsetting ozone layer recovery, Atmos. Chem. Phys., 18, 1379-1394, https://doi.org/10.5194/acp18-1379-2018, 2018.

Bandoro, J., Solomon, S., Santer, B. D., Kinnison, D. E., and Mills, M. J.: Detectability of the impacts of ozone-depleting substances and greenhouse gases upon stratospheric ozone accounting for nonlinearities in historical forcings, Atmos. Chem. Phys., 18, 143-166, https://doi.org/10.5194/acp-18-143-2018, 2018.

Böhringer, H., Fahey, D. W., Fehsenfeld, F. C., and Ferguson, E. E.: The role of ion-molecule reactions in the conversion of $\mathrm{N}_{2} \mathrm{O}_{5}$ to $\mathrm{HNO}_{3}$ in the stratosphere, Planet. Space. Sci., 31, 185-191, 1983.

Bönisch, H., Engel, A., Birner, Th., Hoor, P., Tarasick, D. W., and Ray, E. A.: On the structural changes in the Brewer-Dobson circulation after 2000, Atmos. Chem. Phys., 11, 3937-3948, https://doi.org/10.5194/acp-11-3937-2011, 2011.

Bourassa, A. E., Degenstein, D. A., Randel, W. J., Zawodny, J. M., Kyrölä, E., McLinden, C. A., Sioris, C. E., and Roth, C. Z.: Trends in stratospheric ozone derived from merged SAGE II and Odin-OSIRIS satellite observations, Atmos. Chem. Phys., 14, 6983-6994, https://doi.org/10.5194/acp-14-6983-2014, 2014.

Brinkop, S., Dameris, M., Jöckel, P., Garny, H., Lossow, S., and Stiller, G.: The millennium water vapour drop in chemistryclimate model simulations, Atmos. Chem. Phys., 16, 8125-8140, https://doi.org/10.5194/acp-16-8125-2016, 2016.

Calvo, N., Garcia, R. R., and Kinnison, D. E.: Revisiting Southern Hemisphere polar stratospheric temperature trends in WACCM: The role of dynamical forcing, Geophys. Res. Lett., 44, 3402 3410, https://doi.org/10.1002/2017GL072792, 2017.

Carpenter, L. J., Reimann, S., Burkholder, J. B., Clerbaux, C., Hall, B. D., Hossaini, R., Laube, J. C., and Yvon-Lewis, S. A.: Ozonedepleting substances (ODSs) and other gases of interest to the Montreal Protocol, chap. 1, in: Scientific Assessment of Ozone Depletion: 2014, Global Ozone Research and Monitoring Project - Report No. 55, World Meteorological Organization, Geneva, Switzerland, 2014.

Chipperfield, M. P., Dhomse, S., Hossaini, R., Feng, W., Santee, M. L., Weber, M., Burrows, J. P., Wild, J. D., Loyola, D., and Coldewey-Egbers, M.: On the cause of recent variations in 
lower stratospheric ozone, Geophys. Res. Lett., 45, 5718-5726, https://doi.org/10.1029/2018GL078071, 2018.

Damadeo, R. P., Zawodny, J. M., Thomason, L. W., and Iyer, N.: SAGE version 7.0 algorithm: application to SAGE II, Atmos. Meas. Tech., 6, 3539-3561, https://doi.org/10.5194/amt-6-35392013, 2013.

Davis, S. M., Rosenlof, K. H., Hassler, B., Hurst, D. F., Read, W. G., Vömel, H., Selkirk, H., Fujiwara, M., and Damadeo, R.: The Stratospheric Water and Ozone Satellite Homogenized (SWOOSH) database: a long-term database for climate studies, Earth Syst. Sci. Data, 8, 461-490, https://doi.org/10.5194/essd8-461-2016, 2016.

Dessler, A. E., Schoeberl, M. R., Wang, T., Davis, S. M., Rosenlof, K. H., and Vernier, J.-P.: Variations of stratospheric water vapor over the past three decades, J. Geophys. Res.-Atmos., 119, 12588-12598, https://doi.org/10.1002/2014JD021712, 2014.

Dhomse, S. S., Kinnison, D., Chipperfield, M. P., Salawitch, R. J., Cionni, I., Hegglin, M. I., Abraham, N. L., Akiyoshi, H., Archibald, A. T., Bednarz, E. M., Bekki, S., Braesicke, P., Butchart, N., Dameris, M., Deushi, M., Frith, S., Hardiman, S. C., Hassler, B., Horowitz, L. W., Hu, R.-M., Jöckel, P., Josse, B., Kirner, O., Kremser, S., Langematz, U., Lewis, J., Marchand, M., Lin, M., Mancini, E., Marécal, V., Michou, M., Morgenstern, O., O’Connor, F. M., Oman, L., Pitari, G., Plummer, D. A., Pyle, J. A., Revell, L. E., Rozanov, E., Schofield, R., Stenke, A., Stone, K., Sudo, K., Tilmes, S., Visioni, D., Yamashita, Y., and Zeng, G.: Estimates of ozone return dates from ChemistryClimate Model Initiative simulations, Atmos. Chem. Phys., 18, 8409-8438, https://doi.org/10.5194/acp-18-8409-2018, 2018.

Douglass, A. R., Prather, M. J., Hall, T. M., Strahan, S. E., Rasch, P. J., Sparling, L. C., Coy, L., and Rodriguez, J. M.: Choosing meteorological input for the global modeling initiative assessment of high-speed aircraft, J. Geophys. Res., 104, 27545-27564, 1999.

Douglass, A. R., Strahan, S. E., Oman, L. D., and Stolarski, R. S.: Multi-decadal records of stratospheric composition and their relationship to stratospheric circulation change, Atmos. Chem. Phys., 17, 12081-12096, https://doi.org/10.5194/acp-17-120812017, 2017.

Ern, M., Preusse, P., and Riese, M.: Driving of the SAO by gravity waves as observed from satellite, Ann. Geophys., 33, 483-504, https://doi.org/10.5194/angeo-33-483-2015, 2015.

Eyring, V., Lamarque, J.-F., Hess, P., Arfeuille, F., Bowman, K., Chipperfield, M. P., Duncan, B., Fiore, A., Gettelman, A., Giorgetta, M. A., Granier, C., Hegglin, M., Kinnison, D., Kunze, M., Langematz, U., Luo, B., Martin, R., Matthes, K., Newman, P. A., Peter, T., Robock, A., Ryerson, T., Saiz-Lopez, A., Salawitch, R., Schultz, M., Shepherd, T. G., Shindell, D., Stähelin, J., Tegtmeier, S., Thomason, L., Tilmes, S., Vernier, J.-P., Waugh, D. W., and Young, P.: Overview of IGAC/SPARC Chemistry-Climate Model Initiative (CCMI) Community Simulations in Support of Upcoming Ozone and Climate Assessments, SPARC Newsletter, 40, 48-66, 2013.

Feldman, D. R., Collins, W. D., Biraud, S. C., Risser, M. D., Turner, D. D., Gero, P. J., Tadic, J., Helmig, D., Xie, S., Mlawer, E. J., Shippert, T. R., and Torn, M. S.: Observationally derived rise in methane surface forcing mediated by water vapour trends, Nat. Geosci., 11, 238-246, https://doi.org/10.1038/s41561-018-00859,2018
Frith, S. M., Stolarski, R. S., Kramarova, N. A., and McPeters, R. D.: Estimating uncertainties in the SBUV Version 8.6 merged profile ozone data set, Atmos. Chem. Phys., 17, 14695-14707, https://doi.org/10.5194/acp-17-14695-2017, 2017.

Froidevaux, L., Livesey, N. J., Read, W. G., Salawitch, R. J., Waters, J. W., Drouin, B., MacKenzie, I. A., Pumphrey, H. C., Bernath, P., Boone, C., Nassar, R., Montzka, S., Elkins, J., Cunnold, D., and Waugh, D.: Temporal decrease in upper atmospheric chlorine, Geophys. Res. Lett., 33, L23813, https://doi.org/10.1029/2006GL027600, 2006.

Froidevaux, L., Jiang, Y. B., Lambert, A., Livesey, N. J., Read, W. G., Waters, J. W., Fuller, R. A., Marcy, T. P., Popp, P. J., Gao, R. S., Fahey, D. W., Jucks, K. W., Stachnik, R. A., Toon, G. C., Christensen, L. E., Webster, C. R., Bernath, P. F., Boone, C. D., Walker, K. A., Pumphrey, H. C., Harwood, R. S., Manney, G. L., Schwartz, M. J., Daffer,W.H., Drouin, B. J., Cofield, R. E., Cuddy, D. T., Jarnot, R. F., Knosp, B W., Perun, V. S., Snyder, W. V., Stek, P. C., Thurstans, R. P., and Wagner, P. A.: Validation of Aura Microwave Limb Sounder $\mathrm{HCl}$ measurements, J. Geophys. Res., 113, D15S25, https://doi.org/10.1029/2007JD009025, 2008a.

Froidevaux, L., Jiang, Y. B., Lambert, A., Livesey, N. J., Read, W. G., Waters, J. W., Browell, E. V., Hair, J. W., Avery, M. A., McGee, T. J., Twigg, L. W., Sumnicht, G. K., Jucks, K. W., Margitan, J. J., Sen, B., Stachnik, R. A., Toon, G. C., Bernath, P. F., Boone, C. D., Walker, K. A., Filipiak, M. J., Harwood, R. S., Fuller, R. A., Manney, G. L., Schwartz, M. J., Daffer,W.H., Drouin, B. J., Cofield, R. E., Cuddy, D. T., Jarnot, R. F., Knosp, B. W., Perun, V. S., Snyder, W. V., Stek, P. C., Thurstans, R. P., and Wagner, P. A.: Validation of Aura Microwave Limb Sounder stratospheric and mesospheric ozone measurements, J. Geophys. Res., 113, D15S20, https://doi.org/10.1029/2007JD008771, 2008b.

Froidevaux, L., Anderson, J., Fuller, R. A., Bernath, P. F., Livesey, N. J., Russell III, J. M., and Walker, K. A.: GOZCARDS Merged Hydrogen Chloride 1 month L3 10 degree Zonal Means on a Vertical Pressure Grid V1.01, Greenbelt, MD, USA, Goddard Earth Sciences Data and Information Services Center (GES DISC), https://doi.org/10.5067/MEASURES/GOZCARDS/DATA300, 2013.

Froidevaux, L., Anderson, J., Wang, H.-J., Fuller, R. A., Schwartz, M. J., Santee, M. L., Livesey, N. J., Pumphrey, H. C., Bernath, P. F., Russell III, J. M., and McCormick, M. P.: Global OZone Chemistry And Related trace gas Data records for the Stratosphere (GOZCARDS): methodology and sample results with a focus on $\mathrm{HCl}, \mathrm{H}_{2} \mathrm{O}$, and $\mathrm{O}_{3}$, Atmos. Chem. Phys., 15, $10471-$ 10507, https://doi.org/10.5194/acp-15-10471-2015, 2015.

Fueglistaler, S.: Step-wise changes in stratospheric water vapor?, J. Geophys. Res., 117, D13302, https://doi.org/10.1029/2012JD017582, 2012.

Fueglistaler, S. and Haynes, P. H.: Control of interannual and longer-term variability of stratospheric water vapor, J. Geophys. Res., 110, D24108, https://doi.org/10.1029/2005JD006019, 2005.

Funke, B., Baumgaertner, A., Calisto, M., Egorova, T., Jackman, C. H., Kieser, J., Krivolutsky, A., López-Puertas, M., Marsh, D. R., Reddmann, T., Rozanov, E., Salmi, S.-M., Sinnhuber, M., Stiller, G. P., Verronen, P. T., Versick, S., von Clarmann, T., Vyushkova, T. Y., Wieters, N., and Wissing, J. M.: Composition changes af- 
ter the "Halloween" solar proton event: the High Energy Particle Precipitation in the Atmosphere (HEPPA) model versus MIPAS data intercomparison study, Atmos. Chem. Phys., 11, 90899139, https://doi.org/10.5194/acp-11-9089-2011, 2011.

Garcia, R. R., Marsh, D., Kinnison, D. E., Boville, B., and Sassi, F.: Simulations of secular trends in the middle atmosphere, 1950-2003, J. Geophys. Res., 112, D09301, https://doi.org/10.1029/2006JD007485, 2007.

Garcia, R. R., Smith, A. K., Kinnison, D. E., de la Camara, A., and Murphy, D.: Modification of the gravity wave parameterization in the Whole Atmosphere Community Climate Model: Motivation and results, J. Atmos. Sci., 74, 275-291, https://doi.org/10.1175/JAS-D-16-0104.1, 2017.

Gebhardt, C., Rozanov, A., Hommel, R., Weber, M., Bovensmann, H., Burrows, J. P., Degenstein, D., Froidevaux, L., and Thompson, A. M.: Stratospheric ozone trends and variability as seen by SCIAMACHY from 2002 to 2012, Atmos. Chem. Phys., 14, 831-846, https://doi.org/10.5194/acp-14-831-2014, 2014.

Gille, J., Karol, S., Kinnison, D., Lamarque, J.-F., and Yudin, V.: The role of mid-latitude mixing barriers in creating the annual variation of total ozone in high northern latitudes, J. Geophys. Res., 119, 9578-9595, https://doi.org/10.1002/2013JD0214162014, 2014.

Grooß, J.-U., Müller, R., Spang, R., Tritscher, I., Wegner, T., Chipperfield, M. P., Feng, W., Kinnison, D. E., and Madronich, S.: On the discrepancy of $\mathrm{HCl}$ processing in the core of the wintertime polar vortices, Atmos. Chem. Phys., 18, 8647-8666, https://doi.org/10.5194/acp-18-8647-2018, 2018.

Haenel, F. J., Stiller, G. P., von Clarmann, T., Funke, B., Eckert, E., Glatthor, N., Grabowski, U., Kellmann, S., Kiefer, M., Linden, A., and Reddmann, T.: Reassessment of MIPAS age of air trends and variability, Atmos. Chem. Phys., 15, 13161-13176, https://doi.org/10.5194/acp-15-13161-2015, 2015.

Harris, N. R. P., Hassler, B., Tummon, F., Bodeker, G. E., Hubert, D., Petropavlovskikh, I., Steinbrecht, W., Anderson, J., Bhartia, P. K., Boone, C. D., Bourassa, A., Davis, S. M., Degenstein, D., Delcloo, A., Frith, S. M., Froidevaux, L., Godin-Beekmann, S., Jones, N., Kurylo, M. J., Kyrölä, E., Laine, M., Leblanc, S. T., Lambert, J.-C., Liley, B., Mahieu, E., Maycock, A., de Mazière, M., Parrish, A., Querel, R., Rosenlof, K. H., Roth, C., Sioris, C., Staehelin, J., Stolarski, R. S., Stübi, R., Tamminen, J., Vigouroux, C., Walker, K. A., Wang, H. J., Wild, J., and Zawodny, J. M.: Past changes in the vertical distribution of ozone - Part 3: Analysis and interpretation of trends, Atmos. Chem. Phys., 15, 9965-9982, https://doi.org/10.5194/acp15-9965-2015, 2015.

Hegglin, M. I., Tegtmeier, S., Anderson, J., Froidevaux, L., Fuller, R., Funke, B., Jones, A., Lingenfelser, G., Lumpe, J., Pendlebury, D., Remsberg, E., Rozanov, A., Toohey, M., Urban, J., von Clarmann, T., Walker, K. A., Wang, R., and Weigel, K.: SPARC Data Initiative: Comparison of water vapor climatologies from international satellite limb sounders, J. Geophys. Res.-Atmos., 118, 11824-11846, https://doi.org/10.1002/jgrd.50752, 2013.

Hegglin, M. I., Plummer, D. A., Shepherd, T. G., Scinocca, J. F., Anderson, J., Froidevaux, L., Funke, B., Hurst, D. and Rozanov, A., Urban, J., von Clarmann, T., Walker, K. A., Wang, H. J., Tegtmeier, S., and Weigel, K.: Vertical structure of stratospheric water vapour trends derived from merged satellite data, Nat. Geosci., 7, 768-776, https://doi.org/10.1038/ngeo2236, 2014.
Holton, J. R. and Gettelman, A.:Horizontal transport and the dehydration of the stratosphere, Geophys. Res. Lett., 28, 2799-2802, 2001.

Hossaini, R., Atlas, E., Dhomse, S. S., Chipperfield, M. P., Bernath, P. F., Fernando, A. M., Mühle, J., Leeson, A. A., Montzka, S. A., Feng, W., Harrison, J., Krummel, P., Vollmer, M. K., Reimann, S., O’Doherty, S., Young, D., Maione, M., Arduini, J., and Lunder, C. R. : Recent trends in stratospheric chlorine from very short-lived substances, J. Geophys. Res.-Atmos., 124, 2318-2335, https://doi.org/10.1029/2018JD029400, 2019.

Hubert, D., Lambert, J.-C., Verhoelst, T., Granville, J., Keppens, A., Baray, J.-L., Bourassa, A. E., Cortesi, U., Degenstein, D. A., Froidevaux, L., Godin-Beekmann, S., Hoppel, K. W., Johnson, B. J., Kyrölä, E., Leblanc, T., Lichtenberg, G., Marchand, M., McElroy, C. T., Murtagh, D., Nakane, H., Portafaix, T., Querel, R., Russell III, J. M., Salvador, J., Smit, H. G. J., Stebel, K., Steinbrecht, W., Strawbridge, K. B., Stübi, R., Swart, D. P. J., Taha, G., Tarasick, D. W., Thompson, A. M., Urban, J., van Gijsel, J. A. E., Van Malderen, R., von der Gathen, P., Walker, K. A., Wolfram, E., and Zawodny, J. M.: Ground-based assessment of the bias and long-term stability of $14 \mathrm{limb}$ and occultation ozone profile data records, Atmos. Meas. Tech., 9, 2497-2534, https://doi.org/10.5194/amt-9-2497-2016, 2016.

Hurst, D. F., Oltmans, S. J., Vomel, H., Rosenlof, K. H., Davis, S. M., Ray, E. A., Hall, E. G., and Jordan, A.: Stratospheric water vapor trends over Boulder, Colorado: Analysis of the 30 year Boulder record, J. Geophys. Res., 116, D02306, https://doi.org/10.1029/2010JD015065, 2011.

Hurst, D. F., Read, W. G., Vömel, H., Selkirk, H. B., Rosenlof, K. H., Davis, S. M., Hall, E. G., Jordan, A. F., and Oltmans, S. J.: Recent divergences in stratospheric water vapor measurements by frost point hygrometers and the Aura Microwave Limb Sounder, Atmos. Meas. Tech., 9, 4447-4457, https://doi.org/10.5194/amt-9-4447-2016, 2016.

Imai, K., Manago, N., Mitsuda, C., Naito, Y., Nishimoto, E., Sakazaki, T., Fujiwara, M., Froidevaux, L., von Clarmann, T., Stiller, G. P., Murtagh, D. P., Rong, P.-P., Mlynczak, M. G., Walker, K. A., Kinnison, D. E., Akiyoshi, H., Nakamura, T., Miyasaka, T., Nishibori, T., Mizobuchi, S., Kikuchi, K.-I., Ozeki, H., Takahashi, C., Hayashi, H., Sano, T., Suzuki, M., Takayanagi, M., and Shiotani, M.: Validation of ozone data from the Superconducting Submillimeter-Wave Limb-Emission Sounder (SMILES), J. Geophys. Res.-Atmos., 118, 5750-5769, https://doi.org/10.1002/jgrd.50434, 2013.

Jackman, C. H., Marsh, D. R., Kinnison, D. E., Mertens, C. J., and Fleming, E. L.: Atmospheric changes caused by galactic cosmic rays over the period 1960-2010, Atmos. Chem. Phys., 16, 58535866, https://doi.org/10.5194/acp-16-5853-2016, 2016.

Jensen, E. and Pfister, L.: Transport and freeze-drying in the tropical tropopause layer, J. Geophys. Res.-Atmos., 109, D02207, https://doi.org/10.1029/2003JD004022, 2004.

Jiang, Y. B., Froidevaux, L., Lambert, A., Livesey, N. J., Read, W. G., Waters, J. W., Bojkov, B., Leblanc, T., McDermid, I. S., Godin-Beekmann, S., Filipiak, M. J., Harwood, R. S., Fuller, R. A., Daffer, W. H., Drouin, B. J., Cofield, R. E., Cuddy, D. T., Jarnot, R. F., Knosp, B. W., Perun, V. S., Schwartz, M. J., Snyder, W. V., Stek, P. C., Thurstans, R. P., Wagner, P. A., Allaart, M., Andersen, S. B., Bodeker, G., Calpini, B., Claude, H., Coetzee, G., Davies, J., De Backer, H., Dier, H., Fujiwara, M., 
Johnson, B., Kelder, H., Leme, N. P., Koenig-Langlo, G., Kyro, E., Laneve, G., Fook, L. S., Merrill, J., Morris, G., Newchurch, M., Oltmans, S., Parrondo, M. C., Posny, F., Schmidlin, F., Skrivankova, P., Stubi, R., Tarasick, D., Thompson, A., Thouret, V., Viatte, P., Vömel, H., von Der Gathen, P., Yela, M., and Zablocki, G.: Validation of the Aura Microwave Limb Sounder Ozone by Ozonesonde and Lidar Measurements, J. Geophys. Res., 112, D24S34, https://doi.org/10.1029/2007JD008776, 2007.

Khosrawi, F., Müller, R., Urban, J., Proffitt, M. H., Stiller, G., Kiefer, M., Lossow, S., Kinnison, D., Olschewski, F., Riese, M., and Murtagh, D.: Assessment of the interannual variability and influence of the QBO and upwelling on tracer-tracer distributions of $\mathrm{N}_{2} \mathrm{O}$ and $\mathrm{O}_{3}$ in the tropical lower stratosphere, Atmos. Chem. Phys., 13, 3619-3641, https://doi.org/10.5194/acp13-3619-2013, 2013.

Kinnison, D. E., Brasseur, G. P., Walters, S., Garcia, R. R., Sassi, F., Boville, B. A., Marsh, D., Harvey, L., Randall, C., Randel, W., Lamarque, J.-F., Emmons, L. K., Hess, P., Orlando, J., Tyndall, J., and Pan, L.: Sensitivity of chemical tracers to meteorological parameters in the MOZART3 chemical transport model, J. Geophys. Res., 112, D20302, https://doi.org/10.1029/2006JD007879, 2007.

Kunz, A., Pan, L., Konopka, P., Kinnison, D., and Tilmes, S.: Chemical and dynamical discontinuity at the extratropoical tropopause based on START08 and WACCM analysis, J. Geophys. Res., 116, D24302, https://doi.org/10.1029/2011JD016686, 2011.

Kuttippurath, J., Bodeker, G. E., Roscoe, H. K., and Nair, P. J.: A cautionary note on the use of EESC-based regression analysis for ozone trend studies, Geophys. Res. Lett., 42, 162-168, https://doi.org/10.1002/2014GL062142, 2015.

Kvissel, O.-K., Orsolini, Y. J., Stordal, F., Isaksen, I. S. A., and Santee, M. L.: Formation of stratospheric nitric acid by a hydrated ion cluster reaction: Implications for the effect of energetic particle precipitation on the middle atmosphere, J. Geophys. Res., 117, D16301, https://doi.org/10.1029/2011JD017257, 2012.

Lamarque, J.-F., Emmons, L. K., Hess, P. G., Kinnison, D. E., Tilmes, S., Vitt, F., Heald, C. L., Holland, E. A., Lauritzen, P. H., Neu, J., Orlando, J. J., Rasch, P. J., and Tyndall, G. K.: CAM-chem: description and evaluation of interactive atmospheric chemistry in the Community Earth System Model, Geosci. Model Dev., 5, 369-411, https://doi.org/10.5194/gmd-5369-2012, 2012.

Lambert, A., Read, W. G., Livesey, N. J., Santee, M. L., Manney, G. L., Froidevaux, L., Wu, D. L., Schwartz, M. J., Pumphrey, H. C., Jimenez, C., Nedoluha, G. E., Cofield, R. E., Cuddy, D. T., Daffer, W. H., Drouin, B. J., Fuller, R. A., Jarnot, R. F., Knosp, B. W., Pickett, H. M., Perun, V. S., Snyder, W. V., Stek, P. C., Thurstans, R. P., Wagner, P. A., Waters, J. W., Jucks, K. W., Toon, G. C., Stachnik, R. A., Bernath, P. F., Boone, C. D., Walker, K. A., Urban, J., Murtagh, D., Elkins, J. W., and Atlas, E.: Validation of the Aura Microwave Limb Sounder stratospheric water vapour and nitrous oxide measurements, J. Geophys. Res., 112, D24S36, https://doi.org/10.1029/2007JD008724, 2007.

Lin, S.-J.: A “vertically-Lagrangian” finite-volume dynamical core for global atmospheric models, Mon. Weather Rev., 132, 2293 2307, 2004.

Livesey, N. J., Filipiak, M. J., Froidevaux, L., Read, W. G., Lambert, A., Santee, M. L., Jiang, J. H., Waters, J. W., Cofield,R. E., Cuddy, D. T., Daffer, W. H., Drouin, B. J., Fuller, R. A., Jarnot, R.
F., Jiang, Y. B., Knosp, B. W., Li, Q. B., Perun, V. S., Schwartz, M. J., Snyder,W. V., Stek, P. C., Thurstans, R. P.,Wagner, P. A., Pumphrey, H. C., Avery, M., Browell, E. V., Cammas, J.-P., Christensen, L. E., Edwards, D. P., Emmons, L. K., Gao, R.-S., Jost, H.-J., Loewenstein, M., Lopez, J. D., Nedelec, P., Osterman, G. B., Sachse, G. W., and Webster, C. R.: Validation of Aura Microwave Limb Sounder $\mathrm{O}_{3}$ and $\mathrm{CO}$ observations in the upper troposphere and lower stratosphere, J. Geophys. Res., 113, D15S02, https://doi.org/10.1029/2007JD008805, 2008.

Livesey, N. J., Read, W. G., Froidevaux, L., Lambert, A., Manney, G. L., Pumphrey, H. C., Santee, M. L., Schwartz, M. J., Wang, S., Cofield, R. E., Cuddy, D. T., Fuller, R. A., Jarnot, R. F., Jiang, J. H., Knosp, B. W., Stek, P. C., Wagner, P. A., and Wu, D. L.: EOS MLS Version 4.2x Level 2 data quality and description document, Tech. rep., Jet Propulsion Laboratory D-33509 Rev. D, available at: http://mls.jpl.nasa.gov/ (last access: 4 April 2019), 2018.

Lopez-Puertas, M., Funke, B., Gil-Lopez, S., von Clarmann, T., Stiller, G. P., Höpfner, M., Kellmann, S., Mengistu Tsidu, G., Fischer, H., and Jackman, C. H.: $\mathrm{HNO}_{3}, \mathrm{~N}_{2} \mathrm{O}_{5}$ and $\mathrm{ClONO}_{2}$ Enhancements after the October-November 2003 Solar Proton Events, J. Geophys. Res., 110, A09S44, https://doi.org/10.1029/2005JA011051, 2005.

Lossow, S., Khosrawi, F., Nedoluha, G. E., Azam, F., Bramstedt, K., Burrows, John. P., Dinelli, B. M., Eriksson, P., Espy, P. J., GarcíaComas, M., Gille, J. C., Kiefer, M., Noël, S., Raspollini, P., Read, W. G., Rosenlof, K. H., Rozanov, A., Sioris, C. E., Stiller, G. P., Walker, K. A., and Weigel, K.: The SPARC water vapour assessment II: comparison of annual, semi-annual and quasi-biennial variations in stratospheric and lower mesospheric water vapour observed from satellites, Atmos. Meas. Tech., 10, 1111-1137, https://doi.org/10.5194/amt-10-1111-2017, 2017a.

Lossow, S., Garny, H., and Jöckel, P.: An "island" in the stratosphere - on the enhanced annual variation of water vapour in the middle and upper stratosphere in the southern tropics and subtropics, Atmos. Chem. Phys., 17, 11521-11539, https://doi.org/10.5194/acp-17-11521-2017, 2017b.

Mahieu, E., Chipperfield, M. P., Notholt, J., Reddmann, T., Anderson, J., Bernath, P. F., Blumenstock, T., Coffey, M. T., Dhomse, S. S., Feng, W., Franco, B., Froidevaux, L., Griffith, D. W. T., Hannigan, J. W., Hase, F., Hossaini, R., Jones, N. B., Morino, I., Murata, I., Nakajima, H., Palm, M., Paton-Walsh, C., Russell III, J. M., Schneider, M., Servais, C., Smale, D., and Walker, K. A.: Recent Northern Hemisphere stratospheric $\mathrm{HCl}$ increase due to atmospheric circulation changes, Nature, 515, 104-107, https://doi.org/10.1038/nature13857, 2014.

Marsh, D. R., Mills, M. J., Kinnison, D. E., Lamarque, J.-F., Calvo, N., and Polvani, L. M.: Climate change from 1850 to 2005 simulated in CESM1 (WACCM), J. Climate, 26, 7372-7391, https://doi.org/10.1175/JCLI-D-12-00558.1, 2013.

Matthes, K., Marsh, D. R., Garcia, R. R., Kinnison, D. E., Sassi, F., and Walters, S.: Role of the QBO in modulating the influence of the 11-year solar cycle on the atmosphere using constant forcings, J. Geophys. Res., 115, D18110, https://doi.org/10.1029/2009JD013020, 2010.

Millán, L. F., Livesey, N. J., Santee, M. L., Neu, J. L., Manney, G. L., and Fuller, R. A.: Case studies of the impact of orbital sampling on stratospheric trend detection and derivation of tropical vertical velocities: solar occultation vs. limb 
emission sounding, Atmos. Chem. Phys., 16, 11521-11534, https://doi.org/10.5194/acp-16-11521-2016, 2016.

Morgenstern, O., Hegglin, M. I., Rozanov, E., O’Connor, F. M., Abraham, N. L., Akiyoshi, H., Archibald, A. T., Bekki, S., Butchart, N., Chipperfield, M. P., Deushi, M., Dhomse, S. S., Garcia, R. R., Hardiman, S. C., Horowitz, L. W., Jöckel, P., Josse, B., Kinnison, D., Lin, M., Mancini, E., Manyin, M. E., Marchand, M., Marécal, V., Michou, M., Oman, L. D., Pitari, G., Plummer, D. A., Revell, L. E., Saint-Martin, D., Schofield, R., Stenke, A., Stone, K., Sudo, K., Tanaka, T. Y., Tilmes, S., Yamashita, Y., Yoshida, K., and Zeng, G.: Review of the global models used within phase 1 of the Chemistry-Climate Model Initiative (CCMI), Geosci. Model Dev., 10, 639-671, https://doi.org/10.5194/gmd-10-639-2017, 2017.

Nair, P. J., Godin-Beekmann, S., Kuttippurath, J., Ancellet, G., Goutail, F., Pazmiño, A., Froidevaux, L., Zawodny, J. M., Evans, R. D., Wang, H. J., Anderson, J., and Pastel, M.: Ozone trends derived from the total column and vertical profiles at a northern mid-latitude station, Atmos. Chem. Phys., 13, 10373-10384, https://doi.org/10.5194/acp-13-10373-2013, 2013

Nair, P. J., Froidevaux, L., Kuttippurath, J., Zawodny, J. M., Russell III, J. M., Steinbrecht, W., Claude, H., Leblanc, T., van Gijsel, J. A. E., Johnson, B., Swart, D. P. J., Thomas, A., Querel, R., Wang, R., and Anderson, J.: Subtropical and midlatitude ozone trends in the stratosphere: Implications for recovery, J. Geophys. Res., 120, 7247-7257, https://doi.org/10.1002/2014JD022371, 2015.

Nedoluha, G. E., Gomez, R. M., Hicks, B. C., Wrotny, J. E., Boone, C., and Lambert, A.: Water vapor measurements in the mesosphere from Mauna Loa over solar cycle 23, J. Geophys. Res., 114, D23303, https://doi.org/10.1029/2009JD012504, 2009.

Nisbet, E. G., Dlugokencky, E. J., Manning, M. R., Lowry, D., Fisher, R. E., France, J. L., Michel, S. E., Miller, J. B., White, J. W. C., Vaughn, B., Bousquet, P., Pyle, J. A., Warwick, N. J., Cain, M., Brownlow, R., Zazzeri, G., Lanoisellé, M., Manning, A. C., Gloor, E., Worthy, D. E. J., Brunke, E.-G., Labuschagne, C., Wolff, E. W., and Ganesan, A. L.: Rising atmospheric methane: 2007-2014 growth and isotopic shift, Global Biogeochem. Cy., 30, 1356-1370, https://doi.org/10.1002/2016GB005406, 2016.

Oltmans, S. J., Vömel, H., Hofmann, D. J., Rosenlof, K. H., and Kley, D.: The increase in stratospheric water vapor from balloonborne, frostpoint hygrometer measurements at Washington, D.C., and Boulder, Colorado, Geophys. Res. Lett., 27, 3453$3456,2000$.

Oram, D. E., Ashfold, M. J., Laube, J. C., Gooch, L. J., Humphrey, S., Sturges, W. T., Leedham-Elvidge, E., Forster, G. L., Harris, N. R. P., Mead, M. I., Samah, A. A., Phang, S. M., Ou-Yang, C.-F., Lin, N.-H., Wang, J.-L., Baker, A. K., Brenninkmeijer, C. A. M., and Sherry, D.: A growing threat to the ozone layer from short-lived anthropogenic chlorocarbons, Atmos. Chem. Phys., 17, 11929-11941, https://doi.org/10.5194/acp-17-119292017, 2017.

Orsolini, Y. J., Manney, G. L., Santee, M. L., and Randall, C. E.: An upper stratospheric layer of enhanced $\mathrm{HNO}_{3}$ following exceptional solar storms, Geophys. Res. Lett., 32, L12S01, https://doi.org/10.1029/2004GL021588, 2005.

Perliski, L. M., Solomon, S., and London, J.: On the interpretation of seasonal variations of stratospheric ozone, Planet. Space Sci., 37, 1527-1538, 1989.
Popp, P. J., Marcy, T. P., Watts, L. A., Gao, R. S., Fahey, D. W., Weinstock, E. M., Smith, J. B., Herman, R. L., Troy, R. F., Webster, C. R., Christensen, L. E., Baumgardner, D. G., Voigt, C., Kärcher, B., Wilson, J. C., Mahoney, M. J., Jensen, E. J., and Bui, T. P.: Condensed-phase nitric acid in a tropical subvisible cirrus cloud, Geophys. Res. Lett., 34, L24812, https://doi.org/10.1029/2007GL031832, 2007.

Popp, P. J., Marcy, T. P., Gao, R. S., Watts, L. A., Fahey, D. W., Richard, E. C., Oltmans, S. J., Santee, M. L., Livesey, N. J., Froidevaux, L., Sen, B., Toon, G. C., Walker, K. A., Boone, C. D., and Bernath, P. F.: Stratospheric correlation between nitric acid and ozone, J. Geophys. Res., 114, D03305, https://doi.org/10.1029/2008JD010875, 2009.

Randel, W. J. and Jensen, E. J.: Physical processes in the tropical tropopause layer and their roles in a changing climate, Nat. Geosci., 6, 169-176, https://doi.org/10.1038/ngeo1733, 2013.

Randel, W. J. and Thompson, A. M.: Interannual variability and trends in tropical ozone derived from SAGE II satellite data and SHADOZ ozonesondes, J. Geophys. Res., 116, D07303, https://doi.org/10.1029/2010JD015195, 2011.

Randel, W. J., Wu, F., and Gaffen, D. J.: Interannual variability of the tropical tropopause derived from radiosonde data and NCEP reanalysis, J. Geophys. Res., 105, 15509-15523, 2000.

Randel, W. J., Wu, F., Oltmans, S. J., Rosenlof, K., and Nedoluha, G. E.: Interannual changes of stratospheric water vapor and correlations with tropical tropopause temperatures, J. Atmos. Sci., 61, 2133-2148, 2004

Randel, W. J., Wu, F., Vömel, H., Nedoluha, G. E., and Forster, P.: Decreases in stratospheric water vapor after 2001: Links to changes in the tropical tropopause and the Brewer-Dobson circulation, J. Geophys. Res., 111, D12312, https://doi.org/10.1029/2005JD006744, 2006.

Ray, E. A., Holton, J. R., Fishbein, E., Froidevaux, L., and Waters, J.: The tropical semiannual oscillations in temperature and ozone as observed by the MLS, J. Atmos. Sci., 51, 3045-3052, https://doi.org/10.1175/15200469(1994)051<3045:TTSOIT?>2.0.CO;2, 1994.

Read, W. G., Lambert, A., Bacmeister, J., Cofield, R. E., Christensen, L. E., Cuddy, D. T., Daffer, W. H., Drouin, B. J., Fetzer, E., Froidevaux, L., Fuller, R., Herman, R., Jarnot, R. F., Jiang, J. H., Jiang, Y. B., Kelly, K., Knosp, B. W., Kovalenko, L. J., Livesey, N. J., Liu, H.-C., Manney, G. L., Pickett, H. M., Pumphrey, H. C., Rosenlof, K. H., Sabounchi, X., Santee, M. L., Schwartz, M. J., Snyder, W. V., Stek, P. C., Su, H., Takacs, L. L., Thurstans, R. P., Vömel, H., Wagner, P. A., Waters, J. W., Webster, C. R., Weinstock, E. M., and Wu, D. L.: Aura Microwave Limb Sounder upper tropospheric and lower stratospheric $\mathrm{H}_{2} \mathrm{O}$ and relative humidity with respect to ice validation, J. Geophys. Res., 112, D24S35, https://doi.org/10.1029/2007JD008752, 2007.

Read, W. G., Schwartz, M. J., Lambert, A., Su, H., Livesey, N. J., Daffer, W. H., and Boone, C. D.: The roles of convection, extratropical mixing, and in-situ freeze-drying in the Tropical Tropopause Layer, Atmos. Chem. Phys., 8, 6051-6067, https://doi.org/10.5194/acp-8-6051-2008, 2008.

Rienecker, M., Suarez, M. J., Gelaro, R., Todling, R., Bacmeister, J., Liu, E., Bosilovich, M. G., Schubert, S. D., Takacs, L., Kim, G.-K., Bloom, S., Chen, J., Collins, D., Conaty, A., da Silva, A., Gu, W., Joiner, J., Koster, R. D., Lucchesi, R., Molod, 
A., Owens, T., Pawson, S., Pegion, P., Redder, C. R., Reichle, R., Robertson, J., F. R., Ruddick, A. G., Sienkiewicz, M., and Woollen, J.: MERRA: NASA's Modern-Era Retrospective Analysis for Research and Applications, J. Climate, 24, 3624-3648, https://doi.org/10.1175/JCLI-D-11-00015.1, 2011.

Rohs, S., Schiller, C., Riese, M., Engel, A., Schmidt, U., Wetter, T., Levin, I., Nakazawa, T., and Aoki, S.: Long-term changes of methane and hydrogen in the stratosphere in the period 1978-2003 and their impact on the abundance of stratospheric water vapor, J. Geophys. Res., 111, D14315, https://doi.org/10.1029/2005JD006877, 2006.

Rosenlof, K. H. and Reid, G. R.: Trends in the temperature and water vapor content of the tropical lower stratosphere: Sea surface connection, J. Geophys. Res., 113, D06107, https://doi.org/10.1029/2007JD009109, 2008.

Ryan, N. J., Kinnison, D. E., Garcia, R. R., Hoffmann, C. G., Palm, M., Raffalski, U., and Notholt, J.: Assessing the ability to derive rates of polar middle-atmospheric descent using trace gas measurements from remote sensors, Atmos. Chem. Phys., 18, 14571474, https://doi.org/10.5194/acp-18-1457-2018, 2018.

Sakazaki, T., Shiotani, M., Suzuki, M., Kinnison, D., Zawodny, J. M., McHugh, M., and Walker, K. A.: Sunset-sunrise difference in solar occultation ozone measurements (SAGE II, HALOE, and ACE-FTS) and its relationship to tidal vertical winds, Atmos. Chem. Phys., 15, 829-843, https://doi.org/10.5194/acp-15-8292015, 2015.

Santee, M. L., Lambert, A., Read, W. G., Livesey, N. J., Cofield, R. E., Cuddy, D. T., Daffer, W. H., Drouin, B. J., Froidevaux, L., Fuller, R. A., Jarnot, R. F., Knosp, B. W., Manney, G. L., Perun, V. S., Snyder, W. V., Stek, P. C., Thurstans, R. P., Wagner, P. A., Waters, J. W., Muscari, G., de Zafra, R. L., Dibb, J. E., Fahey, D. W., Popp, P. J., Marcy, T. P., Jucks, K. W., Toon, G. C., Stachnik, R. A., Bernath, P. F., Boone, C. D., Walker, K.A., Urban, J., and Murtagh, D.: Validation of the Aura Microwave Limb Sounder $\mathrm{HNO}_{3}$ measurements, J. Geophys. Res., 112, D24S40, https://doi.org/10.1029/2007JD008, 2007.

Santer, B. D., Wigley, T. M. L., Boyle, J. S., Gaffen, D. J., Hnilo, J. J., Nychka, D., Parker, D. E., and Taylor, K. E.: Statistical significance of trends and trend differences in layer-average atmospheric temperature time series, J. Geophys. Res., 105, 73377356, 2000.

Schaefer, H., Mikaloff Fletcher, S. E., Veidt, C., Lassey, K. R., Brailsford, G. W., Bromley, T. M., Dlugokencky, E. J., Michel, S. E., Miller, J. B., Levin, I., Lowe, D. C., Martin, R. J., Vaughn, B. H., and White, J. W. C.: A 21st century shift from fossil-fuel to biogenic methane emissions indicated by ${ }^{13} \mathrm{CH}_{4}$, Science, 352, 80-84, https://doi.org/10.1126/science.aad2705, 2016.

Scherer, M., Vömel, H., Fueglistaler, S., Oltmans, S. J., and Staehelin, J.: Trends and variability of midlatitude stratospheric water vapour deduced from the re-evaluated Boulder balloon series and HALOE, Atmos. Chem. Phys., 8, 1391-1402, https://doi.org/10.5194/acp-8-1391-2008, 2008.

Schoeberl, M. R., Douglass, A. R., Newman, P. A., Lait, L. R., Lary, D., Waters, J., Livesey, N., Froidevaux, L., Lambert, A., Read,W., Filipiak, M. J., and Pumphrey, H. C.: QBO and annual cycle variations in tropical lower stratosphere trace gases from HALOE and Aura MLS observations, J. Geophys. Res., 113, D05301, https://doi.org/10.1029/2007JD008678, 2008.
Schoeberl, M. R., Dessler, A. E., and Wang, T.: Modeling upper tropospheric and lower stratospheric water vapor anomalies, Atmos. Chem. Phys., 13, 7783-7793, https://doi.org/10.5194/acp13-7783-2013, 2013.

Smith, A. K., Garcia, R. R., Moss, A. C., and Mitchell, N. J.: The semiannual oscillation of the tropical zonal wind in the middle atmosphere derived from satellite geopotential height retrievals, J. Atmos. Sci., 74, 2413-2425, https://doi.org/10.1175/JAS-D-170067.1, 2017.

Solomon, S., Kinnison, D. E., Bandoro, J., and Garcia, R.: Simulations of Polar Ozone Depletion: An Update, J. Geophys. Res., 120, 7958-7974, https://doi.org/10.1002/2015JD0233652015, 2015.

Solomon, S., Ivy, D. J., Kinnison, D., Mills, M. J., Neely III, R. R., and Schmidt, A.: Emergence of healing in the Antarctic ozone layer, Science, 353, 269-274, 2016.

SPARC: SPARC CCMVal Report on the Evaluation of ChemistryClimate Models, edited by: Eyring, V., Shepherd, T., and Waugh, D., SPARC Report No. 5, WCRP-30/2010, WMO/TD No. 40, available at: https://www.sparc-climate.org/publications/ sparc-reports/ (last access: 31 January 2012), 2010.

SPARC: The SPARC Data Initiative: Assessment of stratospheric trace gas and aerosol climatologies from satellite limb sounders, edited by: Hegglin, M. I. and Tegtmeier, S.: SPARC Report No. 8, WCRP-05/2017, https://doi.org/10.3929/ethz-a-010863911, 2017.

Steinbrecht, W., Froidevaux, L., Fuller, R., Wang, R., Anderson, J., Roth, C., Bourassa, A., Degenstein, D., Damadeo, R., Zawodny, J., Frith, S., McPeters, R., Bhartia, P., Wild, J., Long, C., Davis, S., Rosenlof, K., Sofieva, V., Walker, K., Rahpoe, N., Rozanov, A., Weber, M., Laeng, A., von Clarmann, T., Stiller, G., Kramarova, N., Godin-Beekmann, S., Leblanc, T., Querel, R., Swart, D., Boyd, I., Hocke, K., Kämpfer, N., Maillard Barras, E., Moreira, L., Nedoluha, G., Vigouroux, C., Blumenstock, T., Schneider, M., García, O., Jones, N., Mahieu, E., Smale, D., Kotkamp, M., Robinson, J., Petropavlovskikh, I., Harris, N., Hassler, B., Hubert, D., and Tummon, F.: An update on ozone profile trends for the period 2000 to 2016, Atmos. Chem. Phys., 17, 1067510690, https://doi.org/10.5194/acp-17-10675-2017, 2017.

Stiller, G. P., Mengistu Tsidu, G., von Clarmann, T., Glatthor, N., Höpfner, M., Kellmann, S., Linden, A., Ruhnke, R., Fischer, H., Lopez-Puertas, M., Funke, B., and Gil-Lopez, S.: An enhanced $\mathrm{HNO}_{3}$ second maximum in the Antarctic midwinter upper stratosphere 2003, J. Geophys. Res., 110, D20303, https://doi.org/10.1029/2005JD006011, 2005.

Stolarski, R. S., Douglass, A. R., and Strahan, S. E.: Using satellite measurements of $\mathrm{N}_{2} \mathrm{O}$ to remove dynamical variability from $\mathrm{HCl}$ measurements, Atmos. Chem. Phys., 18, 5691-5697, https://doi.org/10.5194/acp-18-5691-2018, 2018.

Stone, K. A., Solomon, S., and Kinnison, D. E.: On the identification of ozone recovery, Geophys. Res. Lett., 45, 5158-5165, https://doi.org/10.1029/2018GL077955, 2018.

Tegtmeier, S., Hegglin, M. I., Anderson, J., Bourassa, A., Brohede, S., Degenstein, D., Froidevaux, L., Fuller, R., Funke, B., Gille, J., Jones, A., Kasai, Y., Krüger, K., Kyrölä, E., Lingenfelser, G., Lumpe, J., Nardi, B., Neu, J., Pendlebury, D., Remsberg, E., Rozanov, A., Smith, L., Toohey, M., Urban, J., von Clarmann, T., Walker, K. A., and Wang, H. J.: The SPARC Data Initiative: A comparison of ozone climatologies from international satel- 
lite limb sounders, J. Geophys. Res.-Atmos., 118, 12229-12247, doi: 10.1002/2013JD019877, 2013.

Tian, W. and Chipperfield, M. P.: Stratospheric water vapor trends in a coupled chemistry-climate model, Geophys. Res. Lett., 33, L06819, https://doi.org/10.1029/2005GL024675, 2006.

Tiao, G. C., Reinsel, G. C., Xu, D., Pedrick, J. H., Zhu, X., Miller, A. J., DeLuisi, J. J., Mateer, C. L., and Wuebbles, D. J.: Effects of autocorrelation and temporal sampling schemes on estimates of trend and spatial correlation, J. Geophys Res., 95, 20507-20517, 1990.

Tilmes, S., Lamarque, J.-F., Emmons, L. K., Kinnison, D. E., Marsh, D., Garcia, R. R., Smith, A. K., Neely, R. R., Conley, A., Vitt, F., Val Martin, M., Tanimoto, H., Simpson, I., Blake, D. R., and Blake, N.: Representation of the Community Earth System Model (CESM1) CAM4-chem within the ChemistryClimate Model Initiative (CCMI), Geosci. Model Dev., 9, 18531890, https://doi.org/10.5194/gmd-9-1853-2016, 2016.

Toohey, M., Hegglin, M. I., Tegtmeier, S., Anderson, J., Añel, J. A., Bourassa, A., Brohede, S., Degenstein, D., Froidevaux, L., Fuller, R., Funke, B., Gille, J., Jones, A., Kasai, Y., Krüger, K., Kyrölä, E., Neu, J. L., Rozanov, A., Smith, L., Urban, J., von Clarmann, T., Walker, K. A., and Wang, R.: Characterizing sampling bias in the trace gas climatologies of the SPARC Data Initiative, J. Geophys. Res.-Atmos., 118, 11847-11862, https://doi.org/10.1002/jgrd.5087, 2013.

Tummon, F., Hassler, B., Harris, N. R. P., Staehelin, J., Steinbrecht, W., Anderson, J., Bodeker, G. E., Bourassa, A., Davis, S. M., Degenstein, D., Frith, S. M., Froidevaux, L., Kyrölä, E., Laine, M., Long, C., Penckwitt, A. A., Sioris, C. E., Rosenlof, K. H., Roth, C., Wang, H.-J., and Wild, J.: Intercomparison of vertically resolved merged satellite ozone data sets: interannual variability and long-term trends, Atmos. Chem. Phys., 15, 3021-3043, https://doi.org/10.5194/acp-15-3021-2015, 2015.

Turner, A. J., Frankenberg, C., Wennberg, P. O., and Jacob, D. J.: Ambiguity in the causes for decadal trends in atmospheric methane and hydroxyl, P. Natl. Acad. Sci. USA, 114, 5367-5372, https://doi.org/10.1073/pnas.1616020114, 2017.

Urban, J., Lossow, S., Stiller, G., and Read, W.: Another drop in water vapor, EOS T. Am. Geophys. Un., 95, 245-252, https://doi.org/10.1002/2014EO270001, 2014.

Verronen, P. T., Santee, M. L., Manney, G. L., Lehmann, R., Salmi, S.-M., and Seppälä, A.: Nitric acid enhancements in the mesosphere during the January 2005 and December 2006 solar proton events, J. Geophys. Res., 116, D17301, https://doi.org/10.1029/2011JD016075, 2011.

von Clarmann, T., Glatthor, N., Höpfner, M., Kellmann, S., Ruhnke, R., Stiller, G. P., and Fischer, H.: Experimental evidence of perturbed odd hydrogen and chlorine chemistry after the October 2003 solar proton events, J. Geophys. Res., 110, A09S45, https://doi.org/10.1029/2005JA011053, 2005.

Vömel, H., Barnes, J. E., Forno, R. N., Fujiwara, M., Hasebe, F., Iwasaki, S., Kivi, R., Komala, N., Kyrölä, E., Leblanc, T., Morel, B., Ogino, S.-Y., Read, W. G., Ryan, S. C., Saraspriya, S., Selkirk, H., Shiotani, M., Valverde Canossa, J., and Whiteman, D. N.: Validation of Aura Microwave Limb Sounder water vapor by balloon-borne Cryogenic Frost point Hygrometer measurements, J. Geophys. Res., 112, D24S37, https://doi.org/10.1029/2007JD008698, 2007.
Wang, R., Froidevaux, L., Anderson, J., Fuller, R. A., Bernath, P. F., McCormick, M. P., Livesey, N. J., Russell III, J. M., Walker, K. A., and Zawodny, J. M.: GOZCARDS Merged Ozone 1 month L3 10 degree Zonal Means on a Vertical Pressure Grid V1.01, Greenbelt, MD, USA, Goddard Earth Sciences Data and Information Services Center (GES DISC), https://doi.org/10.5067/MEASURES/GOZCARDS/DATA3006, 2013.

Waters, J. W., Froidevaux, L., Harwood, R. S., Jarnot, R. F., Pickett, H. M., Read, W. G., Siegel, P. H., Cofield, R. E., Filipiak, M. J., Flower, D. A., Holden, J. R., Lau, G. K., Livesey, N. J., Manney, G. L., Pumphrey, H. C., Santee, M. L., Wu, D. L., Cuddy, D. T., Lay, R. R., Loo, M. S., Perun, V. S., Schwartz, M. J., Stek, P. C., Thurstans, R. P., Boyles, M. A., Chandra, S., Chavez, M. C., Chen, G.-S., Chudasama, B. V., Dodge, R., Fuller, R. A., Girard, M. A., Jiang, J. H., Jiang, Y., Knosp, B. W., LaBelle, R. C., Lam, J. C., Lee, K. A., Miller, M., Oswald, J. E., Patel, N. C., Pukala, D. M., Quintero, O., Scaff, D. M., Snyder, W. V., Tope, M. C., Wagner, P. A., and Walch, M. J.: The Earth Observing System Microwave Limb Sounder (EOS MLS) on the Aura satellite, IEEE T. Geosci. Remote, 44, 1075-1092, https://doi.org/10.1109/TGRS.2006.873771, 2006.

Waugh, D. W. and Eyring, V.: Quantitative performance metrics for stratospheric-resolving chemistry-climate models, Atmos. Chem. Phys., 8, 5699-5713, https://doi.org/10.5194/acp-8-56992008, 2008.

Waugh, D. W., Considine, D. B., and Fleming, E. L.: Is upper stratospheric chlorine decreasing as expected?, Geophys. Res. Lett., 28, 1187-1190, https://doi.org/10.1029/2000GL011745, 2001.

Weatherhead, E. C., Reinsel, G. C., Tiao, G. C., Meng, X.-L., Choi, D., Cheang, W.-K., Keller, T., DeLuisi, J., Wuebbles, D. J., Kerr, J. B., Miller, A. J., Oltmans, S. J., and Frederick, J. E.: Factors affecting the detection of trends: Statistical considerations and applications to environmental data, J. Geophys. Res.-Atmos., 103, 17149-17161, https://doi.org/10.1029/98JD00995, 1998.

Wegner, T., Kinnison, D. E., Garcia, R. R., and Solomon, S.: Simulation of polar stratospheric clouds in the specified dynamics version of the whole atmosphere community climate model, J. Geophys. Res., 4991-5002, https://doi.org/10.1002/jgrd.50415, 2013.

Wilka, C., Shah, K., Stone, K., Solomon, S., Kinnison, D., Mills, M., Schmidt, A., and Neely, R. R., III: The role of heterogeneous chemistry in ozone depletion and recovery, Geophys. Res. Lett., 45, 7835-7842, https://doi.org/10.1029/2018GL078596, 2018.

WMO: Scientific Assessment of Ozone Depletion: 2014, Global Ozone Research and Monitoring Project-Report No. 55, WMO (World Meteorological Organization), Geneva, Switzerland, available at: https://www.esrl.noaa.gov/csd/assessments/ozone (last access: 31 January 2016), 2014.

Wolter, K. and Timlin, M. S.: Monitoring ENSO in COADS with a seasonally adjusted principal component index, in: Proceedings of the 17th Climate Diagnostics Workshop, Norman, OK, NOAA/NMC/CAC, NSSL, Oklahoma Climate Survey, CIMMS and the School of Meteorology, University of Oklahoma, Norman, OK, 52-57, 1993.

Wolter, K. and Timlin, M. S.: Measuring the strength of ENSO events - how does 1997/98 rank?, Weather, 53, 315-324, https://doi.org/10.1002/j.1477-8696.1998.tb06408.x, 1998. 